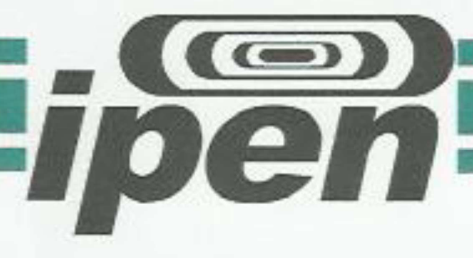

AUTARQUIA ASSOCIADA À UNIVERSIDADE DE SÃO PAULO

INCLUSÃO E REMOÇÃO TÉRMICA DE NaCl, KI E GRAFITE PARA OBTENÇÃO DE CERÂMICAS POROSAS DE ZIRCÔNIA ESTABILIZADA COM ÍTRIA

\author{
SABRINA GONÇALVES DE MACEDO CARVALHO
}

Dissertação apresentada como parte dos requisitos para obtenção do Grau de Mestre em Ciências na Área de Tecnologia Nuclear - Materiais

Orientador:

Prof. Dr. Reginaldo Muccillo 
INSTITUTO DE PESQUISAS ENERGÉTICAS E NUCLEARES

Autarquia associada à Universidade de São Paulo

INCLUSÃO E REMOÇÃO TÉRMICA DE NaCI, KI E GRAFITE PARA OBTENÇÃO DE CERÂMICAS POROSAS DE ZIRCÔNIA ESTABILIZADA COM ÍTRIA

SABRINA GONÇALVES DE MACEDO CARVALHO

Dissertação apresentada como parte dos requisitos para obtenção do Grau de Mestre em Ciências na Área de Tecnologia Nuclear - Materiais

Orientador:

Prof. Dr. Reginaldo Muccillo

Versão Original

Versão Original disponível do IPEN 


\section{AGRADECIMENTOS}

Gostaria de agradecer primeiramente ao Dr. Reginaldo Muccillo pela orientação, ensinamentos e paciência desde a iniciação científica.

À Dra. Eliana N. S. Muccillo, pelas discussões e ensinamentos.

Ao CNPq pela bolsa de Mestrado concedida.

Ao IPEN pela oportunidade de realizar este trabalho.

À Yone V. França pelas análises térmicas e pelo auxílio no laboratório.

Ao Dr. José Roberto Martinelli pelas análises por fluorescência de raios X.

Ao Dr. Douglas Gouvêa e ao Dr. Silvio Miranda pelas análises de porosimetria por intrusão de mercúrio.

Aos colegas do Centro de Ciência e Tecnologia de Materiais, pelas discussões e momentos de descontração.

Não poderia deixar de agradecer aos meus pais, Estevão e Marinilza, sem eles não estaria aqui, e aos meus irmãos Nathália e Matheus.

Em especial ao meu esposo Evandro Bittencourt Cruz, que sempre me apoiou e me ajudou, pela enorme paciência que teve comigo.

E a todos que contribuíram direta ou indiretamente para realização deste trabalho. 


\title{
INCLUSÃO E REMOÇÃO TÉRMICA DE NaCI, KI E GRAFITE PARA OBTENÇÃO DE CERÂMICAS POROSAS DE ZIRCÔNIA ESTABILIZADA COM ÍTRIA
}

\author{
Sabrina Gonçalves de Macedo Carvalho
}

\section{Resumo}

Cerâmicas de zircônia estabilizada com ítria são utilizadas na forma densa como eletrólito e na forma porosa como ânodo em células a combustível de óxido sólido. Neste trabalho cerâmicas porosas de zircônia estabilizada com $8 \mathrm{~mol} \%$ de ítria foram preparadas por meio da adição de diferentes teores de $\mathrm{KI}, \mathrm{NaCl}$ e grafite como aditivo sacrificial. A remoção térmica do aditivo foi avaliada por meio de análises termogravimétrica, térmica diferencial e dilatométrica. As amostras foram preparadas por meio de mistura, compactação e sinterização a $1400 \stackrel{\circ}{\circ} \mathrm{C} / 2$ h. As amostras foram caracterizadas por difração de raios $X(D R X)$ e análise topográfica em microscópio de varredura por sonda e microscópio eletrônico de varredura de superfícies polidas e atacadas para avaliação da distribuição do teor de poros e tamanho médio de grãos. $O$ teor do aditivo residual foi avaliado por fluorescência de raios $X(F R X)$. O comportamento elétrico foi analisado por espectroscopia de impedância (EI) na faixa de frequências $5 \mathrm{~Hz}-10 \mathrm{MHz}$ entre $300^{\circ} \mathrm{C}$ e $450^{\circ} \mathrm{C}$. Os resultados de $\mathrm{FRX}$ mostram que não há resíduo do aditivo após sinterização. $A$ análise de $D R X$ indica que todas as amostras têm fase única, cúbica tipo fluorita. Os diagramas de impedância mostram que há aumento i) das resistividades elétricas intergranular e intragranular, evidenciando a formação de poros em ambas as regiões, ii) do ângulo de descentralização do semicírculo a baixas frequências, devido ao aumento do grau de heterogeneidade pela presença de poros, e iii) do produto do fator de bloqueio $\alpha_{R}$ pelo fator de frequência $\alpha_{f}$, consequência do aumento do teor de poros. Esses resultados estão em concordância com os resultados das análises de microscopia de varredura por sonda e de microscopia eletrônica de varredura.

Palavras-chave: zircônia:ítria, porosidade, espectroscopia de impedância. 


\title{
INCLUSION AND THERMAL REMOVAL OF NaCI, KI AND \\ GRAPHITE FOR PREPARING POROUS YTTRIA-STABILIZED \\ ZIRCONIA CERAMICS: ELECTRICAL AND MICROSTRUCTURAL CHARACTERIZATION
}

Sabrina Gonçalves de Macedo Carvalho

\begin{abstract}
Dense and porous yttria-stabilized zirconia ceramics are used as electrolytes and anodes, respectively, in solid oxide fuel cells. Porous $\mathrm{ZrO}_{2}: 8$ mol\% $\mathrm{Y}_{2} \mathrm{O}_{3}(8 \mathrm{YSZ})$ were prepared by using $\mathrm{NaCl}, \mathrm{KI}$ and graphite as sacrificial additives. The thermal removal of the additives was evaluated by thermogravimetry, differential thermal analysis and dilatometry. The samples were prepared by thoroughly mixing $8 \mathrm{YSZ}$ to the additives, pressing and sintering at $1400 \stackrel{\circ}{\circ} \mathrm{C} / 2 \mathrm{~h}$. The samples were characterized by X-ray diffraction (XRD) and by observation of polished and etched surfaces in scanning probe microscope (SPM) and scanning electron microscope (FEG-SEM) to evaluate pore content. The evaluation of the $\mathrm{NaCl}$ and $\mathrm{KI}$ content was carried out by X-ray fluorescence (XRF) analysis. The electrical behavior was analyzed by impedance spectroscopy (IS) in the $5 \mathrm{~Hz}-10 \mathrm{MHz}$ frequency range from $300^{\circ} \mathrm{C}$ to $450^{\circ} \mathrm{C}$. The $\mathrm{XRF}$ results show no remaining $\mathrm{KI}$ or $\mathrm{NaCl}$ in the sintered samples. The XRD patterns show all samples are single cubic fluorite phase. The IS plots show that there is an increase i) of the intergranular and the intragranular electrical resistivity, an indication of bulk and grain boundary pore formation, ii) of the decentralization angle of the grain boundary semicircle in the impedance plots due to increasing heterogeneity of the samples, and iii) of the product of the blocking factor $\alpha_{R}$ to the frequency factor $\alpha_{f}$, as a consequence of the increase in pore content. These results are in agreement with the SPM and SEM observations.
\end{abstract}

Keywords: YSZ, porosity, impedance spectroscopy. 


\section{Lista de Figuras}

Diagramas de impedância de amostras de zircônia estabilizada com ítria $\left(10 \mathrm{~mol} \% \mathrm{Y}_{2} \mathrm{O}_{3}\right)$ a $688 \mathrm{~K}$ (o número

Figura 1 indica 0 logaritmo da frequência de medida): (a) monocristalina, (b) amostra sinterizada, (c) circuito equivalente que fornece, aproximadamente, o mesmo diagrama da amostra sinterizada ${ }^{[24]}$

Variação, com a temperatura de sinterização, da porosidade e

Figura 2 de $\alpha_{\mathrm{R}} \alpha_{\mathrm{f}}$ de $\mathrm{ZrO}_{2}: 8 \mathrm{~mol}_{\mathrm{O}} \mathrm{Y}_{2} \mathrm{O}_{3}{ }^{[34]}$

Figura 3

Fluxograma de preparação de $\mathrm{ZrO}_{2}: 8 \mathrm{~mol} \% \quad \mathrm{Y}_{2} \mathrm{O}_{3}$ para obtenção de um corpo cerâmico poroso

Figura 4

Curvas de análise termogravimétrica de $\mathrm{ZrO}_{2}: 8$ mol\% $\mathrm{Y}_{2} \mathrm{O}_{3}+$ $x$ peso\% de $(A) \mathrm{KI},(B) \mathrm{NaCl}$ e $(\mathrm{C})$ grafite

Curva termogravimétrica e derivada de $\mathrm{ZrO}_{2}: 8$ mol\% $\mathrm{Y}_{2} \mathrm{O}_{3}+$

Figura 510 peso\% de grafite. A reta vertical indica a temperatura de máxima perda de massa

Curvas de dilatometria de $\mathrm{ZrO}_{2}: 8 \mathrm{~mol} \% \mathrm{Y}_{2} \mathrm{O}_{3}+\mathrm{x}$ peso\% de

Figura 6 (A) $\mathrm{KI},(\mathrm{B}) \mathrm{NaCl}$ e (C) grafite. A flecha indica um zoom da região entre 1380 e $1500^{\circ} \mathrm{C}$

Figura 7

Densidade relativa de $\mathrm{ZrO}_{2}: 8 \mathrm{~mol} \% \mathrm{Y}_{2} \mathrm{O}_{3}+\mathrm{x}$ peso\% de $(\mathrm{A}) \mathrm{KI}$, (B) $\mathrm{NaCl}$ e (C) grafite, $\mathrm{x}=0,1,2,5,10$ e 50

Difratogramas de raios $\mathrm{X}$ de (a) $\mathrm{ZrO}_{2}: 8 \mathrm{~mol} \% \mathrm{Y}_{2} \mathrm{O}_{3}$, (b) +1

Figura 8 peso $\% \mathrm{KI},(\mathrm{c})+10$ peso $\% \mathrm{KI},(\mathrm{d})+1$ peso $\% \mathrm{NaCl},(\mathrm{e})+10$ peso $\% \mathrm{NaCl},(\mathrm{f})+1$ peso $\%$ grafite e $(\mathrm{g})+10$ peso $\%$ grafite .....

Micrografias obtidas por microscopia eletrônica de varredura

Figura 9 (1) e por microscopia de varredura por sonda (2) de $\mathrm{ZrO}_{2}: 8$ mol\% $\mathrm{Y}_{2} \mathrm{O}_{3}+\mathrm{x}$ peso\% de KI, $\mathrm{x}=0$ (a), 1 (b), 2 (c), 5 (d), 10 (e)

Histogramas de distribuição de tamanhos de grãos para

Figura 10 amostras sinterizadas de $\mathrm{ZrO}_{2}: 8 \mathrm{~mol} \% \mathrm{Y}_{2} \mathrm{O}_{3}+\mathrm{x}$ peso $\%$ de iodeto de potássio como aditivo sacrificial, sendo $x=0(a), 1$ (b), 2 (c), 5 (d) , 10 (e) e 50 (f)

Micrografias de $\mathrm{ZrO}_{2}: 8$ mol\% $\mathrm{Y}_{2} \mathrm{O}_{3}+50$ peso\% de $\mathrm{KI}$, com

Figura 11 aumento de $200 x$ para análise da porosidade. À esquerda a imagem foi cortada para tirar as informações da medida, e à direita após o ajuste threshold

Figura 12

Porosidade da amostra sinterizadas de $\mathrm{ZrO}_{2}: 8 \mathrm{~mol} \% \mathrm{Y}_{2} \mathrm{O}_{3}$ em função do teor de iodeto de potássio adicionado

Figura 13 Micrografias obtidas por microscopia eletrônica de varredura 
(1) e por microscopia de varredura por sonda (2) de $\mathrm{ZrO}_{2}: 8$ mol\% $\mathrm{Y}_{2} \mathrm{O}_{3}+\mathrm{x}$ peso\% de NaCl, $\mathrm{x}=0$ (A), 1 (B), 2 (C), 5 (D) e $10(\mathrm{E})$

Figura 14 Tamanho médio de grão das amostras de $\mathrm{ZrO}_{2}: 8$ mol\% $\mathrm{Y}_{2} \mathrm{O}_{3}$ em função do teor de cloreto de sódio adicionado.

Figura 15

Histogramas de distribuição de tamanhos de grão para amostras sinterizadas de $\mathrm{ZrO}_{2}: 8 \mathrm{~mol} \% \mathrm{Y}_{2} \mathrm{O}_{3}+\mathrm{x}$ peso\% de cloreto de sódio como aditivo sacrificial, sendo $x=0$ (a), 1 (b), 2 (c), 5 (d) e 10 (e)

Figura 16 Porosidade da amostra sinterizada de $\mathrm{ZrO}_{2}: 8$ mol\% $\mathrm{Y}_{2} \mathrm{O}_{3}$ em função do teor de cloreto de sódio adicionado

Micrografias obtidas por microscopia eletrônica de varredura

Figura 17 de $\mathrm{ZrO}_{2}: 8 \mathrm{~mol} \% \mathrm{Y}_{2} \mathrm{O}_{3}+\mathrm{x}$ peso\% de grafite, $\mathrm{x}=0$ (a), 1 (b), 2 (c), 5 (d) e 10 (e)

Histogramas de distribuição de tamanhos de grãos para

Figura 18 amostras sinterizadas de $\mathrm{ZrO}_{2}: 8 \mathrm{~mol} \% \mathrm{Y}_{2} \mathrm{O}_{3}+\mathrm{x}$ peso\% de grafite como aditivo sacrificial, sendo $x=0$ (a), 1 (b), 2 (c), 5 (d) e 10 (e)

Figura 19 Porosidade da amostra sinterizada de $\mathrm{ZrO}_{2}: 8$ mol\% $\mathrm{Y}_{2} \mathrm{O}_{3}$ em função do teor de grafite adicionado

Diagramas de impedância de $\mathrm{ZrO}_{2}: \mathrm{Y}_{2} \mathrm{O}_{3}+x$ peso\% de (a) $\mathrm{KI}$ Figura 20 medidos a $323{ }^{\circ} \mathrm{C}$, (b) $\mathrm{NaCl}$ medidos a $325{ }^{\circ} \mathrm{C}$ e (c) grafite medidos a $329{ }^{\circ} \mathrm{C}$. Os números representam o logaritmo da frequência do sinal aplicado

Variação do ângulo de descentralização $\beta$ do semicírculo do

Figura 21 diagrama de impedância para as amostras de zircônia:ítria com diferentes teores de iodeto de sódio (a) e de cloreto de sódio (b)

Figura 22

Circuito equivalente composto por uma resistência em paralelo com um Elemento de Fase Constante

Resistividade do grão e do contorno de grão de $\mathrm{ZrO}_{2}: 8 \mathrm{~mol} \%$

Figura $23 \quad \mathrm{Y}_{2} \mathrm{O}_{3}$, em função do teor do formador de poro adicionado. (a) $\mathrm{KI}$, (b) $\mathrm{NaCl}$ e (c) grafite

Variação do fator de bloqueio (a), fator de frequência (b) e o

Figura 24 produto (c) entre esses dois fatores $\left(\alpha_{R} \cdot \alpha_{f}\right)$ com o teor de KI adicionado a $\mathrm{ZrO}_{2}: 8 \mathrm{~mol} \% \mathrm{Y}_{2} \mathrm{O}_{3}$.

Valores do fator de bloqueio (a), do fator de frequência (b) e do

Figura 25 produto (c) entre esses dois fatores $\left(\alpha_{R} \cdot \alpha_{f}\right)$ com o teor de $\mathrm{NaCl}$ adicionado a $\mathrm{ZrO}_{2}: 8$ mol\% $\mathrm{Y}_{2} \mathrm{O}_{3}$ 
Figura 26 Valores do fator de bloqueio (a), do fator de frequência (b) e do 49 produto (c) entre esses dois fatores $\left(\alpha_{R} \cdot \alpha_{f}\right)$ com 0 teor de grafite adicionado a $\mathrm{ZrO}_{2}: 8 \mathrm{~mol} \% \mathrm{Y}_{2} \mathrm{O}_{3}$ 


\section{Lista de Tabelas}

Teor de massa eliminada durante a análise térmica de $\mathrm{ZrO}_{2}: 8$

Tabela $1 \mathrm{~mol} \% \mathrm{Y}_{2} \mathrm{O}_{3}+\mathrm{x}$ peso\% de iodeto de potássio, cloreto de sódio e grafite

Tabela 2 Teor de iodeto de potássio e cloreto de sódio nas amostras de $\mathrm{ZrO}_{2}: 8 \mathrm{~mol} \% \mathrm{Y}_{2} \mathrm{O}_{3}+\mathrm{x}$ peso\% do aditivo, antes da sinterização

Tamanho médio de grão $(G)$ das amostras sinterizadas de

Tabela $3 \quad \mathrm{ZrO}_{2}: 8 \mathrm{~mol} \% \mathrm{Y}_{2} \mathrm{O}_{3}$ para os diferentes teores de iodeto de potássio adicionados. Incerteza representa a dispersão no valor do tamanho médio $\mathrm{G}$

Tabela 4 Porosidade das amostras sinterizadas de $\mathrm{ZrO}_{2}: 8$ mol\% $\mathrm{Y}_{2} \mathrm{O}_{3}$ para os diferentes teores de iodeto de potássio adicionados ....

Tamanho médio de grão $(G)$ das amostras sinterizadas de

Tabela $5 \mathrm{ZrO}_{2}: 8 \mathrm{~mol} \% \mathrm{Y}_{2} \mathrm{O}_{3}$ para os diferentes teores de cloreto de sódio adicionados. DV é o desvio padrão e representa a dispersão no valor do tamanho médio $\mathrm{G}$

Tabela 6 Porosidade das amostras sinterizadas de $\mathrm{ZrO}_{2}: 8$ mol\% $\mathrm{Y}_{2} \mathrm{O}_{3}$ para os diferentes teores de cloreto de sódio adicionados

Tamanho médio de grão $(G)$ das amostras sinterizadas de

Tabela $7 \quad \mathrm{ZrO}_{2}: 8 \mathrm{~mol} \% \mathrm{Y}_{2} \mathrm{O}_{3}$ para os diferentes teores de grafite adicionados. DV é o desvio padrão e representa a dispersão no valor do tamanho médio $\mathrm{G}$

Tabela 8 Porosidade das amostras sinterizadas de $\mathrm{ZrO}_{2}: 8$ mol\% $\mathrm{Y}_{2} \mathrm{O}_{3}$ para os diferentes teores de grafite adicionados

Valores de $\mathrm{Q}$ do grão e do contorno de grão para amostras de

Tabela $9 \mathrm{ZrO}_{2}: 8 \mathrm{~mol} \% \quad \mathrm{Y}_{2} \mathrm{O}_{3}$ com diferentes teores de iodeto de potássio, cloreto de sódio e grafite 


\section{Sumário}

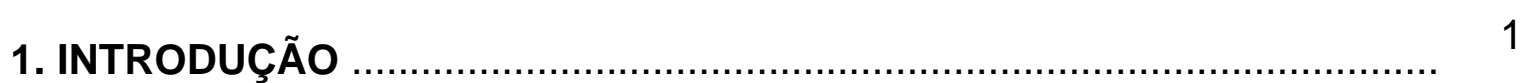

1.1. Zircônia:ítria ............................................................................ 1

1.2. Cerâmicas porosas ...................................................................... 2

1.3. Anodos para SOFC ................................................................. 4

1.4. Espectroscopia de impedância ................................................. 5

1.5. Objetivos ........................................................................ 11

2. MATERIAIS E MÉTODOS ….......................................................... 12

2.1. Materiais de partida ............................................................ 12

2.2. Preparação de amostras ........................................................... 12

2.3. Técnicas de Análise ............................................................... 13

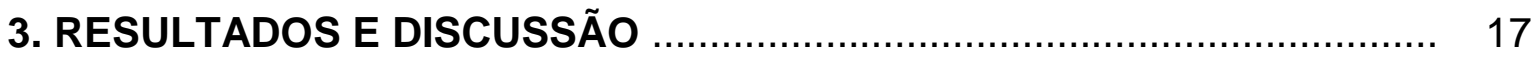

3.1. Preparação ......................................................................... 17

3.2. Caracterização ........................................................................ 25

3.3. Procedimento para preparação de cerâmicas porosas de 50 zircônia:ítria .......................................................................................... 50

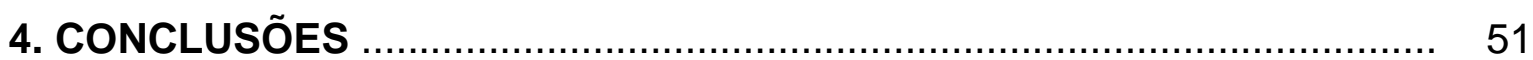

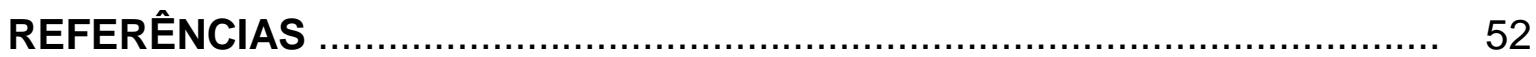




\section{INTRODUÇÃO}

\subsection{Zircônia:ítria}

A zircônia $\left(\mathrm{ZrO}_{2}\right)$, à pressão ambiente, apresenta três estruturas cristalinas: monoclínica, tetragonal e cúbica. As temperaturas de transformação de fase da zircônia são:

$$
\text { monoclínica } \stackrel{1170^{\circ} \mathrm{C}}{\longrightarrow} \text { tetragonal } \stackrel{2370^{\circ} \mathrm{C}}{\longrightarrow} \text { cúbica } \stackrel{2680^{\circ} \mathrm{C}}{\longrightarrow} \text { líquida }
$$

A zircônia apresenta transformação tetragonal-cúbica apenas acima de $2300^{\circ} \mathrm{C}$. A adição de íons de terras raras ou outros cátions aliovalentes à zircônia mostraram a estabilização da fase cúbica a temperaturas menores, facilitando seu estudo ${ }^{[1]}$.

A zircônia cúbica estabilizada apresenta elevada resistência mecânica, tenacidade e resistência a choque térmico ${ }^{[1]}$. Além disso, a adição de cátions substitucionais induz a geração de vacâncias de oxigênio para compensação de carga, o que faz da zircônia cúbica estabilizada um condutor de íons de oxigênio, sendo utilizada em sensores de oxigênio, em bomba de oxigênio para regulação da pressão parcial, e em células a combustível operacionais a altas temperaturas.

A solução sólida mais estudada é a de zircônia:ítria devido às suas boas propriedades mecânicas e elétricas. Dentre as diferentes proporções de ítria adicionadas à zircônia, a mais estudada é a zircônia contendo $8 \mathrm{~mol} \%$ de ítria $\left(\mathrm{ZrO}_{2}: 8 \mathrm{~mol} \% \mathrm{Y}_{2} \mathrm{O}_{3}\right)$, devido a sua estrutura cúbica do tipo fluorita, sendo esse teor o que proporciona o mais alto valor de condutividade iônica.

Cerâmicas policristalinas de composição $\quad \mathrm{ZrO}_{2}: 8$ mol\% $\quad \mathrm{Y}_{2} \mathrm{O}_{3}$ são materiais eletrocerâmicos muito importantes, principalmente por causa de sua condutividade elétrica acima da temperatura ambiente. São amplamente utilizadas em dispositivos comerciais, tais como sensores de oxigênio (para a medição do teor de oxigênio no cano de escapamento de veículos, a fim de otimizar a relação ar-combustível em motores de combustão para um menor consumo de combustível e diminuição da poluição) e em células a combustível de óxido sólido. 


\subsection{Cerâmicas porosas}

Cerâmicas policristalinas podem ser preparadas com baixo teor de poros ou com teor controlado de porosidade, dependendo da aplicação. Assim como as cerâmicas não porosas, as cerâmicas com teor controlado de poros devem ser densas, isto é, com alta densidade esqueletal, para suportar esforços mecânicos nas condições de operação do dispositivo do qual a cerâmica faz parte.

Em praticamente todos os campos da tecnologia é possível reconhecer que muitos dispositivos, em componentes simples e complexos, contêm algum grau de porosidade controlada, que o ajusta para fornecer um conjunto propriedades necessárias a seu funcionamento. É, de fato, a combinação única de características que materiais porosos possuem que prolongam significativamente suas propriedades ${ }^{[2]}$.

Enquanto que a porosidade não intencional em um material é algo negativo e muito esforços são investidos para evitá-la, a porosidade intencional e projetada está se tornando mais prevalente em materiais avançados. Muitos benefícios se originam da introdução deliberada de vazios e poros em materiais com parâmetros geométricos controlados. Os procedimentos de processamento do material poroso afetam bastante sua morfologia e arquitetura; portanto, o desenvolvimento e inovação na fabricação são fatores chaves para permitir a fabricação de componentes possuindo características de porosidade desejadas ${ }^{[2]}$.

Materiais porosos encontram atualmente muitas aplicações como produtos finais e em diferentes processos tecnológicos. Contrariamente às estruturas porosas em metais e polímeros, poros tem sido tradicionalmente evitados em componentes cerâmicos, devido a sua natureza inerentemente frágil. Entretanto, um número crescente de aplicações que requer cerâmicas porosas tem vindo à tona nas últimas décadas, especialmente para ambientes nos quais, a altas temperaturas, extenso desgaste e meios corrosivos estão envolvidos. Tais aplicações incluem, por exemplo, a filtração de metais fundidos, isolamento térmico a alta temperatura, suporte para as reações catalíticas, filtração de partículas dos gases de escape de motores a diesel, e de filtragem de gases corrosivos em vários processos industriais e componentes de células a combustível ${ }^{[3,4]}$. As vantagens de utilização de materiais porosos nestas aplicações são geralmente o elevado ponto de fusão e a alta resistência a desgaste e corrosão, em combinação com as características obtidas pela substituição do material sólido por espaços vazios no componente. Tais características incluem uma baixa massa térmica, baixa condutividade térmica, permeabilidade controlada, alta área superficial, baixa densidade, alta resistência 
específica e baixa constante dielétrica ${ }^{[5-8]}$. Essas propriedades podem ser controladas para cada aplicação específica controlando a composição e a microestrutura da cerâmica porosa. Alterações na porosidade aberta e fechada, distribuição do tamanho de poro e a morfologia do poro podem ter efeito importante nas propriedades do material. Todas essas características microestruturais são, por sua vez, fortemente influenciadas pela rota de processamento utilizada para produção do material poroso ${ }^{[8]}$.

Inúmeras técnicas foram desenvolvidas para produzir cerâmicas porosas ${ }^{[8]} \mathrm{e}$ ainda vem sendo desenvolvidas ${ }^{[9-11]}$, a fim de melhorar as propriedades finais do corpo poroso. Dentre as técnicas desenvolvidas, as mais utilizadas são: de formação de espuma, da réplica e dos moldes sacrificiais.

A formação de espuma consiste na introdução de gás em um líquido, que produz bolhas por pressão interna. O gás pode ser introduzido por espumação mecânica (mistura ou agitação, para incorporar bolhas), fazendo borbulhar um gás através do líquido, através da separação de um gás dissolvido (por exemplo, alterando a solubilidade do sistema), ou pela geração in situ de gás dentro do líquido, por uma reação química, ou por decomposição térmica de uma agente ou evaporação de um solvente. $A$ morfologia da espuma depende de diversos fatores influenciados pelo processo, incluindo a taxa de nucleação das bolhas do gás ${ }^{[12]}$.

A réplica consiste num processo de revestimento de um molde poroso aberto, possuindo um esqueleto sólido contínuo. Esta técnica foi proposta em 1964 para lamas cerâmicas e ainda é o mais utilizado em indústrias para a fabricação de espumas cerâmicas utilizadas como filtros de metais fundidos. O molde pode ser uma espuma polimérica ou um componente biológico, tal como madeira ou papel montado em uma estrutura macroporosa, a qual é então queimada durante um tratamento térmico aplicado para a sinterização das partículas ${ }^{[12]}$.

A técnica de molde sacrificial consiste na preparação de uma composição bifásica composta pelas partículas de cerâmica e um material sacrificial, que é distribuído homogeneamente por todo material cerâmico, e depois extraído para gerar os poros. Essa extração depende do tipo de formador de poro utilizado. Normalmente o material sacrificial é oxidado, decomposto ou vaporizado durante a sinterização, gerando ou deixando poros na estrutura da cerâmica ${ }^{[4]}$. Diferentes tipos de formador de poro são utilizados, incluindo amido ${ }^{[13,14]}$, fibras orgânicas ${ }^{[15]}$, e sais ${ }^{[3]}$. Uma vantagem particular deste método de fabricação é o controle preciso da quantidade total de poros, bem como na forma e dimensão dos poros obtidos. 


\subsection{Anodos para SOFC}

Células a combustível de óxido sólido (SOFC) são dispositivos eletroquímicos que convertem energia química de combustíveis gasosos, como hidrogênio e gás natural, em energia elétrica, produzindo corrente contínua. A célula a combustível de óxido sólido é basicamente composta por um eletrólito sólido e dois eletrodos porosos, o anodo e o catodo. No catodo (eletrodo em contato com o ar), o oxigênio reage com os elétrons do circuito externo para se transformar em íon oxigênio, que migra através do eletrólito em direção ao anodo. No anodo (eletrodo em contato com o combustível) os íons de oxigênio oxidam o combustível, liberando elétrons que fluem no circuito externo. A corrente eletrônica no circuito externo é balanceada pela corrente iônica no eletrólito ${ }^{[16,17]}$.

Portanto, os eletrólitos sólidos devem ser materiais que possuam condução iônica e que sejam isolantes eletrônicos. Suas principais funções são a de separar os gases reagentes, impedir a corrente eletrônica no circuito interno da célula e promover a condução iônica que balanceia a corrente eletrônica externa ${ }^{[17]}$.

O catodo é a interface entre o ar e o eletrólito e suas principais funções são conduzir elétrons do circuito externo até o sítio da reação de redução e catalisar a reação de redução do oxigênio ${ }^{[17]}$. Já o anodo é a interface entre o eletrólito e o combustível, que promove sítios para as reações de oxidação do combustível com os íons provenientes do eletrólito, permite a difusão do combustível para os sítios reativos da interface eletrodo/eletrólito e a remoção dos produtos gerados, e transporta os elétrons gerados para o circuito externo ${ }^{[18,19]}$.

Os materiais mais comuns utilizados para produção de SOFC são zircônia estabilizada com ítria (YSZ) para o eletrólito sólido, manganita de lantânio dopado com estrôncio para o catodo e YSZ/níquel para o anodo ${ }^{[16]}$.

O cermet poroso de Ni/YSZ é o material mais usado para o anodo, principalmente devido ao seu baixo custo. É quimicamente estável em altas temperaturas sob atmosfera redutora, e o coeficiente de expansão térmica é próximo ao do eletrólito de YSZ. Para utilização como anodo é necessário que o cermet possua uma porosidade maior que $30 \%$ em volume, a fim de permitir o transporte do reagente e dos produtos gasosos ${ }^{[18]}$.

O níquel é um ótimo reformador catalítico e eletrocatalítico para a oxidação eletroquímica do hidrogênio e promove uma condutividade eletrônica predominante para o anodo. A zircônia estabilizada com ítria constitui uma rede para dispersão das 
partículas de níquel e age como um inibidor do crescimento exagerado do tamanho de partícula do pó de níquel durante a consolidação e operação ${ }^{[19]}$.

$\mathrm{O}$ anodo de $\mathrm{Ni} / \mathrm{YSZ}$ é normalmente fabricado utilizando pós comerciais de $\mathrm{NiO}$ e YSZ, que são homogeneizados por mistura e moagem mecânica e dissolvidos em composto orgânico para permitir sua deposição em camada no eletrólito sólido. A solução contendo NiO/YSZ formada é aplicada em um eletrólito de YSZ e o conjunto é sinterizado a fim de formar um cermet poroso de Ni/YSZ. O desempenho e as propriedades elétricas do cermet são fortemente influenciados pelo processo de fabricação, pelas características dos pós precursores, sinterização da YSZ, entre outras características que influenciam na microestrutura e distribuição das fases Ni e YSZ ${ }^{[20]}$.

Devido à necessidade de um material poroso para aplicação como anodo de células a combustível de óxido sólido, grafite é adicionado como formador de poros. Para cada $10-20$ peso\% de grafite adicionado, a porosidade do anodo aumenta $\sim 10 \%{ }^{[21]}$.

\subsection{Espectroscopia de Impedância}

A espectroscopia de impedância foi introduzida como uma técnica precisa de determinação da condutividade de eletrólitos sólidos por Bauerle ${ }^{[22]}$ em 1969. Desde então tem se tornado uma ferramenta muito importante no estudo de materiais, pois seus resultados podem frequentemente ser relacionados com a microestrutura, composição de fases, homogeneidade, impureza do material analisado.

A técnica de espectroscopia de impedância consiste em aplicar um sinal alternado de baixa amplitude (para evitar respostas não lineares), medir a corrente correspondente e determinar a variação da impedância $Z(\omega)=R e Z+i \operatorname{Im~} Z$, com a frequência ${ }^{[23]}$. $O$ diagrama de impedância consiste em um plano complexo $\operatorname{Im~} Z \times f(\operatorname{Re} Z)$, no qual a extremidade do vetor impedância descreve a curva característica do sistema estudado em função da frequência. O diagrama de impedância de um monocristal dielétrico é um semicírculo no primeiro quadrante ${ }^{[24]}$ e corresponde a um circuito equivalente constituído de uma resistência em paralelo com uma capacitância. Para um dielétrico policristalino, composto por grãos e contornos de grão, é possível observar dois semicírculos no diagrama de impedância (Figura 1b). 

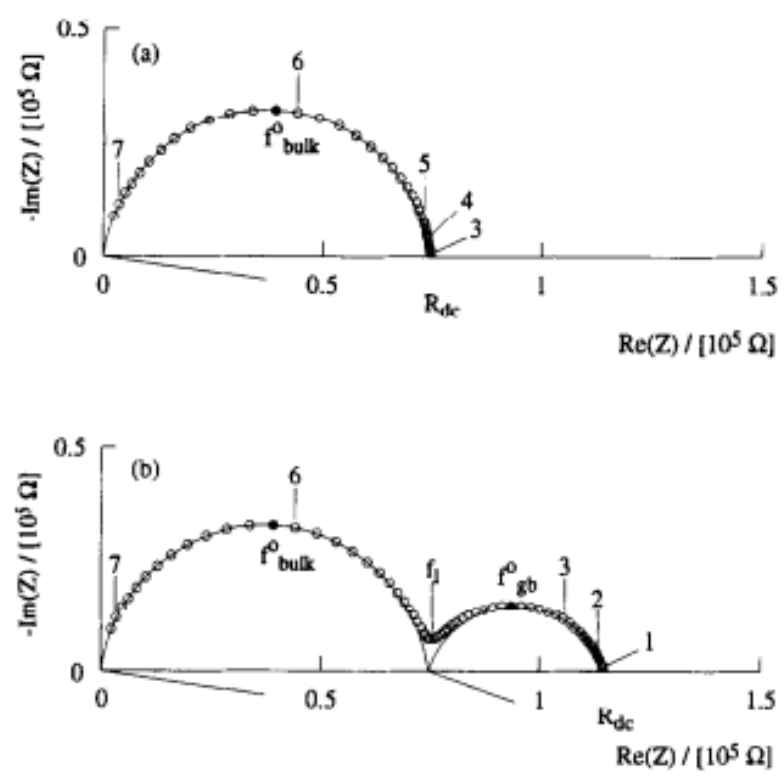

(c)

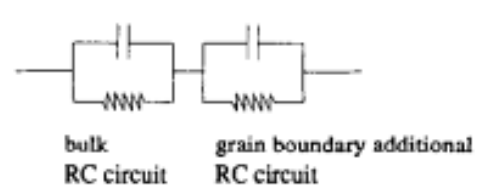

Figura 1 - Diagramas de impedância de amostras de zircônia estabilizada com ítria (10 mol\% $\left.\mathrm{Y}_{2} \mathrm{O}_{3}\right)$ a $688 \mathrm{~K}$ (o número indica o logaritmo da frequência de medida): (a) monocristalina, (b) amostra sinterizada, (c) circuito equivalente que fornece, aproximadamente, o mesmo diagrama da amostra sinterizada $^{[24]}$.

O comportamento elétrico apresentado no diagrama de impedância (Figura 1b) pode ser associado a circuitos $\mathrm{RC}$ equivalentes (Figura 1c), no qual se tem uma resistência $\mathrm{R}$ em paralelo com uma capacitância $\mathrm{C}$, resultado da resistência e das propriedades dielétricas do material analisado.

Na representação em admitância, $Y(\omega)=1 / Z(\omega)$, os diâmetros dos semicírculos representam as condutâncias $\Sigma$ e a resposta dos contornos de grão é caracterizada por uma condutância de bloqueio $\sum_{\text {cg. }}$. $O$ termo capacitivo $\mathrm{C}_{\mathrm{cg}}$ associado a este bloqueio é obtido na relação $\left(2 \pi \mathrm{C}_{\mathrm{cg}} \mathrm{f}_{\mathrm{ocg}} / \Sigma_{\mathrm{cg}}\right)=1$, na qual $\mathrm{f}_{0 \mathrm{cg}}$ é a frequência no apex do semicírculo. As medidas ac podem também ser analisadas em planos complexos de admitância $Y(\omega)$ $=\operatorname{Re} Y+i \operatorname{Im} Y=1 / Z(\omega)$ e de módulo $M(\omega)=\operatorname{Re} M+i \operatorname{Im} M=i \omega C Z(\omega)$, sendo $C a$ capacitância da célula vazia ${ }^{[25]}$.

É importante notar que circuitos equivalentes compostos por componentes ideais (Figura 1c) nem sempre descrevem adequadamente o sistema físico real. Esses sistemas são descritos corretamente quando é incluído no circuito um Elemento de Fase 
Constante (EFC) ${ }^{[23]}$. O elemento de fase constante é um dipolo com dois parâmetros: uma pseudo-capacitância $Q$ e um expoente $p$. Seu comportamento elétrico não pode ser reproduzido pela combinação de $\mathrm{R}, \mathrm{C}$ e L. A impedância complexa de um elemento EFC e dada pela Equação (1.4.1) ${ }^{[26]}$ :

$$
Z_{E F C}(\omega)=Q^{-1}(j \omega)^{-p}, \quad 0 \leq p \leq 1
$$

sendo $\omega$ a frequência angular, j o número imaginário e $p=2 \beta / \pi$, na qual $\beta$ é o ângulo de descentralização do semicírculo no diagrama de impedância. É conferido ao EFC uma componente real, isto é, resistiva, para qualquer valor de $\mathrm{p}$ diferente de 1 , que não apresenta a capacitância clássica, como mostra a Equação (1.4.2):

$$
Z_{E F C}(\omega)=\frac{Q \omega^{p} \cos \frac{p \pi}{2}}{\left(Q \cos \frac{p \pi}{2}\right)^{2}+\left(Q \omega^{p} \sin \frac{p \pi}{2}\right)^{2}}-j\left[\frac{Q \omega^{p} \sin \frac{p \pi}{2}}{\left(Q \omega^{p} \cos \frac{p \pi}{2}\right)^{2}+\left(Q \omega^{p} \sin \frac{p \pi}{2}\right)^{2}}\right]
$$

Em função dos valores de $p$, o EFC se comporta como dipolo puro. Quando $p=1$, $Z(\omega)=1 / Q(j \omega)$, tem-se um circuito com capacitância ideal, sendo $C=Q$ e quando $p=0$, $Z(\omega)=1 / Q$, circuito com resistência ideal sendo $R=1 / Q^{[26]}$. A frequência de relaxação $\omega_{0}$ de um circuito formado por um resistor paralelo com o EFC é dado pela Equação (1.4.3):

$$
\omega_{0}=\frac{1}{(R A)^{1 / P}}
$$

O elemento de fase constante é originado pela distribuição na densidade de corrente ao longo da superfície do eletrodo como resultado de uma superfície não homogênea.

O ângulo de descentralização (Figura 1a e 1b) do semicírculo formado está relacionado com a homogeneidade da microestrutura da amostra. Em um circuito ideal, composto por um capacitor em paralelo com um resistor, o centro do semicírculo se encontra no eixo x. Um monocristal apresenta valores baixos para o ângulo de descentralização, próximos a zero, pois não possui contornos de grão, enquanto que amostras policristalinas apresentam valores superiores a zero, quanto maior a heterogeneidade, maior o valor de $\beta$. 
Portanto, quando o ângulo de descentralização do semicírculo do diagrama de impedância é maior que zero não é correto utilizar um capacitor para representar o circuito equivalente, deve-se utilizar o EFC.

Estudos mostram que, além dos grãos e contornos de grãos, também é possível utilizar a espectroscopia de impedância para caracterizar fraturas, poros e outros defeitos de microestrutura em materiais cerâmicos ${ }^{\text {[24, 27-29]. }}$.

Cerâmicas porosas têm comportamento elétrico diferente de cerâmicas não porosas. Os poros podem ser considerados defeitos de volume que impedem o transporte de carga, atuando como bloqueadores ${ }^{[24,29,30]}$. As linhas de corrente devidas à aplicação de um campo elétrico externo podem contornar os poros, produzindo uma modificação nos diagramas de impedância de eletrólitos sólidos na região de baixas frequências (respostas intergranular). Em outras palavras, o caminho livre médio dos portadores de carga através da cerâmica submetida a um campo elétrico é maior em uma região porosa do que em uma região sem poros. Este comportamento, isto é, a modificação do diagrama de impedância na região de baixas frequências, já foi reportado para o caso de trincas em eletrólitos sólidos à base de zircônia ${ }^{[27]}$ e para cerâmicas porosas de zircônia:ítria ${ }^{[28]}$.

Para caracterizar essa resistência à passagem de portadores de carga pela região intergranular quando submetidos a estes defeitos, foi definido o fator de bloqueio $\alpha_{R}$, conforme Equação (1.4.4) ${ }^{[27,32]}$.

$$
\alpha_{R}=\frac{R_{c g}}{R_{g}+R_{c g}}
$$

sendo $R_{c g}$ a resistência dos contornos de grão e $R_{g}$ a resistência dos grãos.

Esse fator é um parâmetro adimensional que representa a fração de portadores de carga bloqueados nos defeitos de microestrutura, com relação ao número total de portadores de carga. O fator de bloqueio é proporcional à área bloqueadora equivalente, normal ao campo elétrico, ou seja, proporcional à área média entre os grãos, à superfície média de poros ${ }^{[27,29,31]}$. Por ser um fator adimensional, pode ser calculado também através de um diagrama de admitância, pela razão entre a condutância do contorno de grão $\left(\Sigma_{c g}\right)$ e a condutância total $\left(\Sigma_{g}+\Sigma_{c g}\right)$, e independe do fator geométrico da amostra estudada, facilitando sua comparação com outros estudos. 
Outro parâmetro importante no estudo de cerâmicas porosas por espectroscopia de impedância é o fator de capacitância, $\alpha_{C}$, esse fator permite a determinação da relação entre o volume de poros e o volume de grãos ( $\mathrm{G}^{3}$, sendo $\mathrm{G}$ o tamanho médio de grão). $\alpha_{C}$ pode ser calculado pelo quociente entre a capacitância do contorno de grão $\left(C_{c g}\right)$ e a capacitância do grão $\left(C_{g}\right)$, conforme Equação (1.4.5) ${ }^{[27,32] \text { : }}$

$$
\alpha_{C}=\frac{C_{c g}}{C_{g}}
$$

sendo a capacitância calculada por (1.4.6):

$$
\frac{C_{g}}{\Sigma_{g}} \cdot 2 \pi \cdot f_{o g}=1
$$

na qual $f_{\text {og }}$ é a frequência característica da resistividade do grão.

Utilizando (1.4.4), (1.4.5) e (1.4.6), estabelece-se uma relação entre $\alpha_{C}$ e $\alpha_{R}$, explicitada na Equação (1.4.7):

$$
\frac{\alpha_{R}}{\alpha c}=\frac{f_{o c g}}{f_{o g}}=\alpha_{f}
$$

O fator de frequência $\alpha_{f}$, também adimensional, é obtido pelo quociente entre a frequência característica da resistividade do contorno de grão pela frequência característica da resistividade do grão. Este parâmetro é proporcional à espessura média do bloqueador ou a distância média intergranular.

A multiplicação dos fatores $\alpha_{R} . \alpha_{f}$ é proporcional ao volume entre os grãos, ou seja, ao volume de poros ${ }^{[24,31,33,34]}$, conforme Figura 2. 


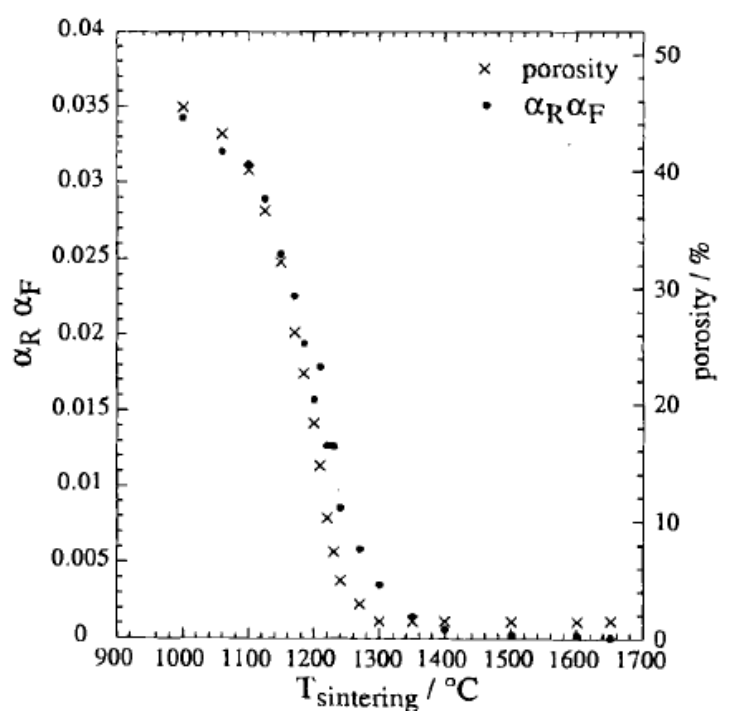

Figura 2 - Variação, com a temperatura de sinterização, da porosidade e do produto $\alpha_{\mathrm{R} .} \alpha_{\mathrm{f}}$ de $\mathrm{ZrO}_{2}: 8$ $\mathrm{mol} \% \mathrm{Y}_{2} \mathrm{O}_{3}{ }^{[34]}$.

Assim, a evolução do processo de sinterização pode ser seguida por meio da determinação deste produto que, em primeira aproximação, corresponde à eliminação de poros ${ }^{[33]}$ e consequente aumento da densidade. Neste caso, a técnica de espectroscopia de impedância complementa a de dilatometria e de microscopia eletrônica de varredura, permitindo contribuir para o estudo da relação microestrutura-propriedades.

Estudos comprovaram que fraturas, poros e segunda fase, considerados defeitos de microestrutura, se comportam de maneira similar ao contorno de grão, em zircônia estabilizada com ítria (YSZ). Dessa forma, qualquer modelo para o contorno de grão também deve explicar o comportamento elétrico desses defeitos de microestrutura ${ }^{[31]}$. Sendo assim, pode-se utilizar os parâmetros $\alpha_{f}$ e $\alpha_{R}$ para auxiliar não apenas no estudo de contorno de grão, mas também para estudar a porosidade de zircônia estabilizada com ítria. 


\subsection{Objetivos}

\section{$\underline{\text { Gerais }}$}

- Preparar cerâmica porosa de zircônia:ítria, por meio de inclusão e remoção térmica de $\mathrm{KI}$ e $\mathrm{NaCl}$, e comparar com o método que utiliza grafite como aditivo sacrificial.

\section{Específicos}

- Preparar cerâmicas porosas utilizando diferentes teores de iodeto de potássio e de cloreto de sódio.

- Determinar a temperatura ótima para eliminação dos aditivos.

- Avaliar o teor de poros por microscopia de varredura por sonda e microscopia eletrônica de varredura.

- Avaliar o comportamento elétrico e estudar qualitativamente a porosidade do material por espectroscopia de impedância.

- Elaboração de roteiro para obtenção de zircônia:ítria porosa utilizando halogeneto alcalino. 


\section{MATERIAIS E MÉTODOS}

\subsection{Materiais de partida}

Foram utilizados para a preparação dos compactos cerâmicos de zircônia:ítria os seguintes materiais:

- Zircônia estabilizada com 8 mol\% de ítria (Tosoh, Japão)

- Cloreto de sódio (comercial)

- lodeto de potássio (comercial)

- Grafite (Nacional de Grafite Ltda., Minas Gerais, Brasil)

\subsection{Preparação de amostras}

Foram preparadas amostras de zircônia:ítria $\left(\mathrm{ZrO}_{2}: 8\right.$ mol\% $\left.\mathrm{Y}_{2} \mathrm{O}_{3}\right)$ com diferentes porcentagens de iodeto de potássio $(\mathrm{KI})$, cloreto de sódio $(\mathrm{NaCl})$ e grafite, por meio de homogeneização em almofariz de ágata aquecido por $2 \mathrm{~h}$ em estufa a $100 \stackrel{\circ}{\circ}$, devido a higroscopicidade de $\mathrm{KI}$ e de $\mathrm{NaCl}$.

Foram preparadas 16 misturas, cada uma variando a porcentagem de $\mathrm{KI}, \mathrm{NaCl}$ e grafite a ser adicionada ao pó comercial de zircônia:ítria:

- $0,1,2,5,10$ e 50 peso\% de $\mathrm{KI}$

- $0,1,2,5$ e 10 peso\% de $\mathrm{NaCl}$

- $0,1,2,5$ e 10 peso\% de grafite

Após as misturas, os pós foram compactados uniaxialmente a $50 \mathrm{MPa} / 1 \mathrm{~min}$ em uma prensa (Kratos) com matrizes metálicas, de diâmetro $10 \mathrm{~mm}$ e $5 \mathrm{~mm}$, e isostaticamente (prensa National Forge Company) a $200 \mathrm{MPa} / 1 \mathrm{~min}$.

Todas as amostras foram tratadas termicamente em forno resistivo tubular com a seguinte programação: taxa de aquecimento e resfriamento de $5^{\circ} \mathrm{C} / \mathrm{min}$, e com dois patamares, o primeiro a $\mathrm{T} / 1 \mathrm{~h}$ e o segundo a $1400{ }^{\circ} \mathrm{C} / 2 \mathrm{~h}$, sendo que $\mathrm{T}$ variou de acordo com o material presente na mistura. Para o Kl, esta temperatura foi $\sim 690{ }^{\circ} \mathrm{C}$ e para o $\mathrm{NaCl} \sim 800 \stackrel{\circ}{\circ}$, valores próximos ao ponto de fusão dos aditivos, e para o grafite a temperatura $\mathrm{T}$ foi $750 \stackrel{\circ}{\circ} \mathrm{C}$, determinada pela temperatura de máxima perda de massa obtida pela derivada da curva termogravimétrica. 
O fluxograma da Figura 3 ilustra o processo de preparação e obtenção da cerâmica porosa de zircônia:ítria.

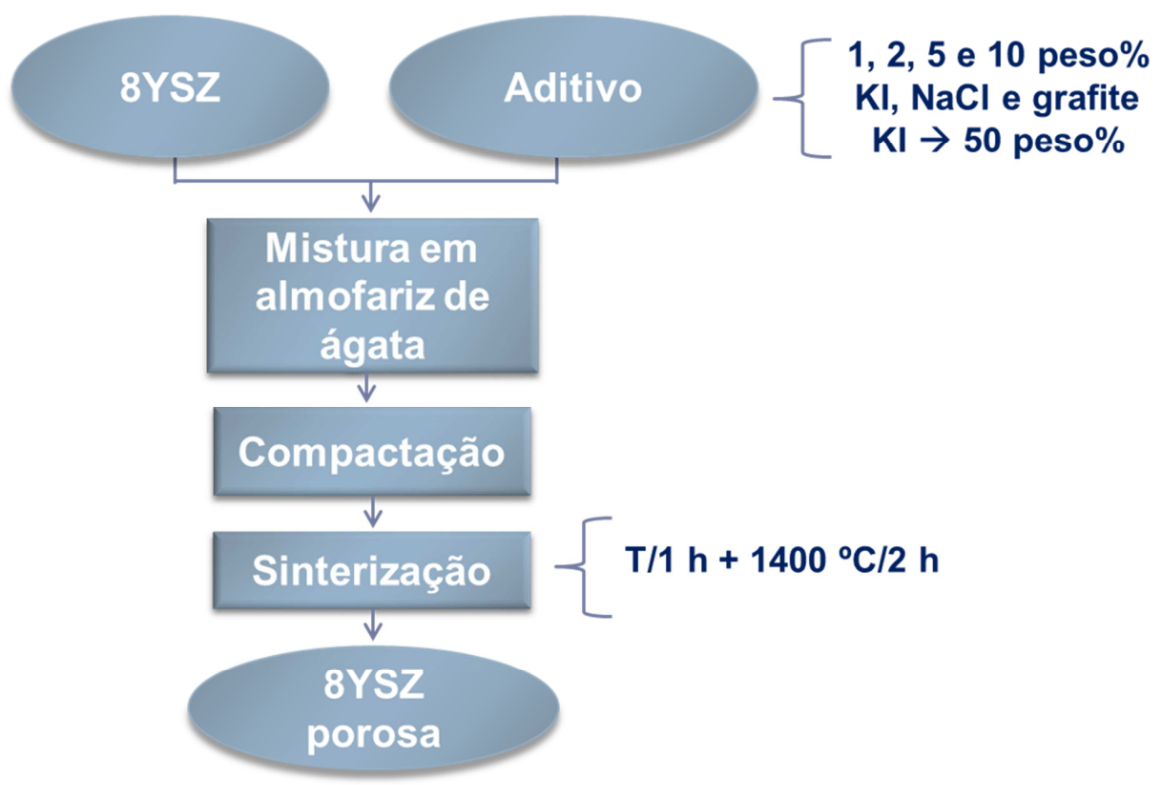

Figura 3 - Fluxograma de preparação de $\mathrm{ZrO}_{2}: 8$ mol\% $\mathrm{Y}_{2} \mathrm{O}_{3}$ para obtenção de um corpo cerâmico poroso.

\subsection{Técnicas de Análise}

\section{Análise térmica}

A análise termogravimétrica das misturas com diferentes porcentagens de $\mathrm{KI}$, $\mathrm{NaCl}$ e grafite foi feita com taxa de aquecimento $5 \stackrel{\circ}{\circ} / \mathrm{min}$ até $1200 \stackrel{\circ}{\circ}$ sob atmosfera de ar sintético. Para todas as análises, o material de referência foi alumina-a e o equipamento utilizado foi o de análise térmica simultânea Netzsch STA 402-E.

A análise dilatométrica, para o estudo da retração linear, foi feita em dilatômetro Anter 1161 sob as seguintes condições: taxa de aquecimento $5 \stackrel{\circ}{\circ} / \mathrm{min}$ até $1500{ }^{\circ} \mathrm{C}$ e de resfriamento $10^{\circ} \mathrm{C} / \mathrm{min}$ sob atmosfera estática ambiente.

\section{Fluorescência de raios $\mathrm{X}$}

Com o objetivo de determinar a presença de iodeto de potássio e de cloreto de sódio em cada amostra, antes e depois da sinterização, foram feitas análises de 
fluorescência de raios $X$, por dispersão de energia, sob vácuo, com tubo de tungstênio e alvo de ródio, tensões de 15 e 50 kV, em equipamento Shimadzu EDX-720.

\section{Difração de raios $X$}

As amostras sinterizadas foram analisadas por difração de raios $X$ em um difratômetro Bruker-AXS D8 Advance com radiação Cu-ka, nas condições: tensão 40 kV, corrente $40 \mathrm{~mA}$, faixa angular $20^{\circ}-80^{\circ}(2 \theta)$, com passo $0,05^{\circ}$ e tempo por passo $2 \mathrm{~s}$. Os difratogramas foram indexados por comparação com os arquivos do banco de dados ICDD (82-1246).

\section{Densidade aparente}

As medidas de densidade foram de duas formas:

Densidade geométrica com utilização de micrômetro (Tesa) e balança analítica digital (Mettler Toledo AB204). Esse método consiste na obtenção da densidade por determinação das dimensões e da massa da amostra.

Densidade pela técnica de Arquimedes em meio líquido (água), em balança (Mettler Toledo AG245). Nesse método a amostra é imersa em água destilada, fervida para que o líquido seja introduzido nos poros abertos, e resfriada ao ar. Quando em temperatura ambiente são realizadas as determinações das massas imersa $\left(m_{i}\right)$ e úmida $\left(m_{u}\right)$ e registrada a temperatura da água e do ar para determinação da densidade. A amostra é então colocada em estufa para secagem e posterior medição da massa seca $\left(m_{s}\right)$. A densidade hidrostática $\left(\rho_{h}\right)$ é determinada pela Equação (2.3.1):

$$
\rho_{h}=\frac{\rho_{l} \cdot m_{s}-\rho_{a r} \cdot m_{i}}{m_{u}-m_{i}}
$$

sendo $\rho_{\mathrm{l}}$ a densidade no líquido e $\rho_{\mathrm{ar}}$ a densidade do ar.

\section{Porosidade}

A porosidade de algumas amostras foi analisada por porosimetria de mercúrio. Esta técnica relaciona a pressão aplicada ao sistema amostra/mercúrio com o volume de mercúrio introduzido, podendo analisar poros entre $500 \mu \mathrm{m}$ e $3,5 \mathrm{~nm}$. Primeiramente a amostra é colocada no penetrômetro e o bombeamento para eliminação do ar e da umidade residual é iniciado; o penetrômetro é então preenchido com mercúrio ainda sob pressão reduzida. A pressão aplicada é aumentada para que o mercúrio entre nos poros grandes ou em possíveis vazios entre as amostras. O primeiro ponto de dados é tomado quando a pressão atinge aproximadamente 0,5 psi e termina quando atinge 10.000 psi; 
neste momento as medidas de "baixa pressão" terminaram. O penetrômetro é retirado do equipamento, aferida a sua massa para posterior determinação da densidade do compacto e então é colocado novamente no equipamento em um sistema de "alta pressão" no qual é cercado por um fluído hidráulico capaz de exercer pressão de até 60.000 psi ${ }^{[35]}$. O equipamento no qual as medidas foram feitas foi o Micromeritics Autopore III.

\section{Análises topográficas de superfície}

Para a observação dos compactos em microscópio foi necessário o polimento. Para isso os compactos cerâmicos foram seccionados em cortadora Isomet (Buehler) com disco adiamantado. Após este processo as amostras foram embutidas em uma resina própria para impregnação, com preenchimento sob vácuo dos poros facilitando o polimento.

Para polir foram usadas pastas adiamantadas de 6 e de $1 \mu \mathrm{m}$, em pano de polimento (Buehler) colocado no disco de uma máquina politriz (Arotec, Aropol E) com suporte para seis amostras. Este disco gira com velocidade escolhida, enquanto as amostras ficam presas ao suporte para que ocorra o polimento.

Foi feito ataque térmico para revelar os contornos de grão. $O$ tratamento térmico foi feito a $1300{ }^{\circ} \mathrm{C} / 15 \mathrm{~min}, 100{ }^{\circ} \mathrm{C}$ abaixo da temperatura de sinterização.

Os compactos foram observados em microscópio eletrônico de varredura de alta resolução (FEG, FEI Inspect F50) e em microscópio de varredura por sonda (JEOL JSPM - 5200), em força atômica no modo contato, no qual a sonda que varre amostra interage com a mesma pela força de Van der Waals, fornecendo informações sobre a topografia por meio de um transdutor piezoelétrico de $100 \mu \mathrm{m} \times 100 \mu \mathrm{m}$.

Imagens obtidas por microscopia de varredura por sonda e por microscopia eletrônica de varredura foram analisadas com o programa computacional Image $\mathrm{J}^{[36]}$.

\section{Determinação de tamanho médio de grão}

O tamanho médio de grão das amostras polidas e atacadas foi determinado por meio do método de Mendelson ${ }^{[37]}$, ou método dos interceptos. O tamanho médio de grão G é obtido pelo produto entre a média dos interceptos medidos $(\bar{e})$ e uma constante de proporcionalidade, conforme Equação (2.3.2):

$$
G=1,56 . \bar{e}
$$




\section{Espectroscopia de impedância}

Para as medidas elétricas das cerâmicas porosas sinterizadas, foram pintadas as faces paralelas com prata coloidal (Ticon), sendo efetuado tratamento térmico a 150 ○C/15 min para eliminação do componente orgânico. As medidas foram feitas em câmara porta-amostra de alumina e inconel, que possibilita a colocação de 3 amostras, inserida em forno resistivo, em atmosfera ambiente. A temperatura foi monitorada com termopar de cromel-alumel, cuja força eletromotriz é monitorada por multímetro Agilent 970E. O comportamento elétrico foi analisado por espectroscopia de impedância na faixa de frequência de $5 \mathrm{~Hz}$ a $13 \mathrm{~Hz}$, entre $300{ }^{\circ} \mathrm{C}$ e $450 \stackrel{\circ}{\mathrm{C}}$ em analisador de impedância Hewlett Packard 4192A com controlador HP 360 da série 900. Um programa especial foi utilizado para coleta de dados [Z”' $\omega)$ x Z'( $\omega)$ ] e deconvolução dos diagramas de impedância ${ }^{[38]}$. 


\section{RESULTADOS E DISCUSSÃO}

Esta seção é dividida em três subseções principais: a primeira referente à preparação do material poroso, a segunda sobre a caracterização da porosidade, e a terceira com um roteiro experimental para preparação de amostras porosas por meio de adição/remoção de halogeneto alcalino.

\subsection{Preparação}

Após a mistura em almofariz de ágata do pó de zircônia:ítria com os três diferentes aditivos, uma alíquota foi retirada para análise termogravimétrica a fim de avaliar a eliminação do aditivo durante o aquecimento. Os resultados desta análise estão dispostos nas Figuras 4a, 4b e 4c para iodeto de potássio, cloreto de sódio e grafite, respectivamente. 


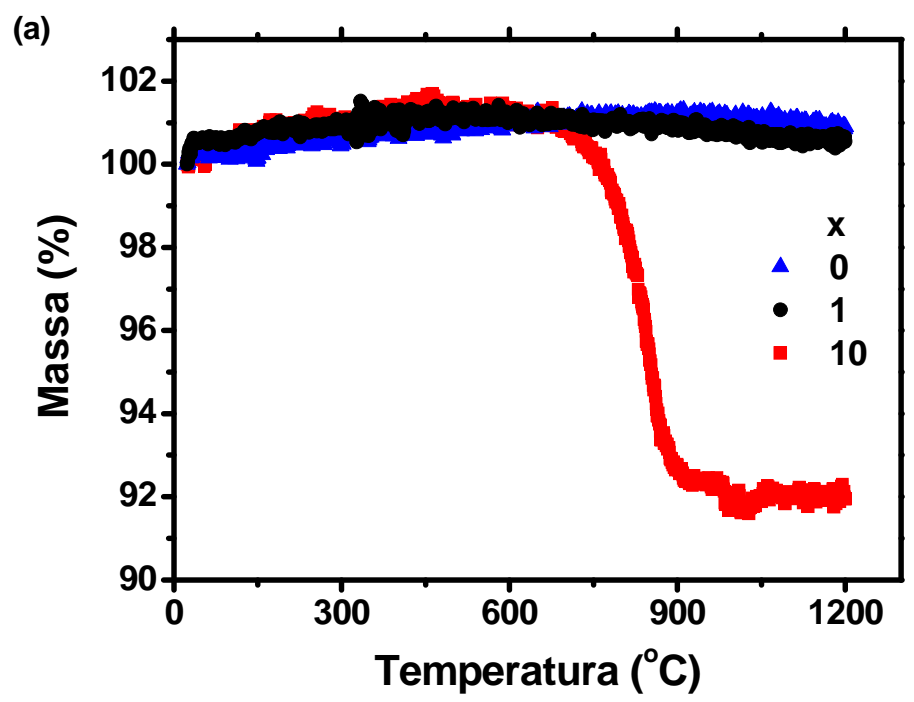

(B)

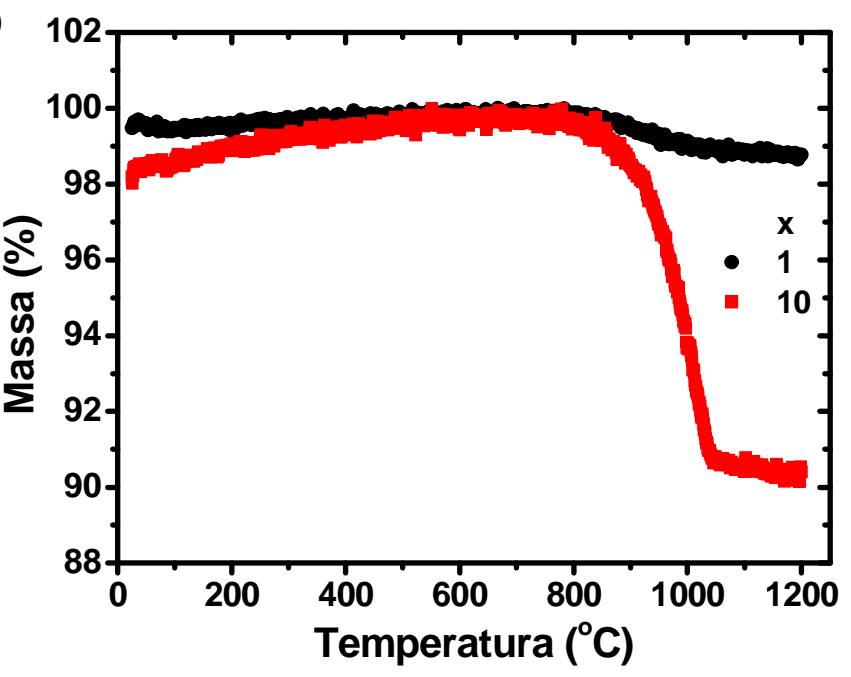

(C)

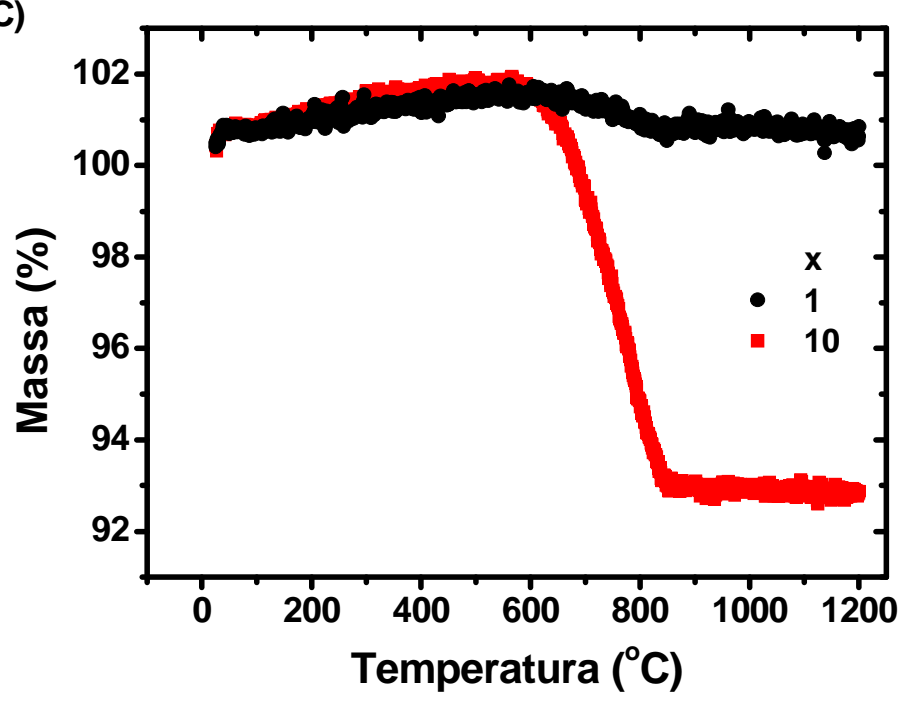

Figura 4 - Curvas de análise termogravimétrica de $\mathrm{ZrO}_{2}: 8$ mol\% $\mathrm{Y}_{2} \mathrm{O}_{3}+x$ peso\% de (A) $\mathrm{KI}$, (B) $\mathrm{NaCl}$ e (C) grafite. 
Na curva do material sem KI (Figura 4a, $x=0$ ) não ocorre perda de massa durante o aquecimento. Perdas ocorrem apenas na zircônia:ítria com adição de iodeto de potássio, sendo o teor de redução de massa proporcional à quantidade de aditivo. Essa perda de massa inicia-se na faixa $700-800^{\circ} \mathrm{C}$, próximo à temperatura de fusão do $\mathrm{KI}$ $\left(686^{\circ} \mathrm{C}\right)$.

Assim como para o iodeto de potássio, na curva da mistura com cloreto de sódio Figura $4 \mathrm{~b}$ - a perda de massa ocorre na faixa próxima à temperatura de fusão do aditivo, 800 - $900 \stackrel{\circ}{\circ}$, e os valores experimentais de perda de massa estão de acordo com os percentuais nominais adicionados.

Para as misturas com grafite - Figura $4 \mathrm{c}$ - a eliminação do aditivo ocorre na faixa $600-800 \stackrel{\circ}{\circ}$, e novamente os valores de perda de massa estão de acordo com os valores adicionados durante a preparação das misturas. A Tabela 1 mostra o cálculo da perda de massa em cada análise relacionando-as com os valores nominais adicionados.

Tabela 1 - Teor de massa eliminada durante a análise térmica de $\mathrm{ZrO}_{2}: 8 \mathrm{~mol} \% \mathrm{Y}_{2} \mathrm{O}_{3}+\mathrm{x}$ peso\% de iodeto de potássio, cloreto de sódio e grafite.

\begin{tabular}{c|ccc}
\hline $\mathbf{X}$ & \multicolumn{3}{|c}{ Massa (\%) } \\
& $\mathbf{K I}$ & $\mathbf{N a C l}$ & grafite \\
\hline 0 & 0,0 & - & - \\
1 & 1,1 & 1,1 & 0,9 \\
10 & 10,0 & 9,5 & 9,2 \\
\hline
\end{tabular}

A perda de massa das misturas está de acordo com os valores nominais adicionados, indicando a eliminação durante o tratamento térmico.

A temperatura $\mathrm{T}$ do primeiro patamar de sinterização, para eliminação do aditivo dos compactos com cloreto de sódio e iodeto de potássio, foi determinada pela temperatura de fusão; dessa forma, pode-se utilizar uma temperatura mais baixa que a temperatura de máxima perda de massa, e os possíveis resíduos dos aditivos em poros abertos podem ser eliminados durante a colocação das amostras em água em ebulição.

Entretanto, a temperatura $\mathrm{T}$ para a mistura com grafite foi determinada pela temperatura de máxima perda de massa, obtida a partir da derivada da curva termogravimétrica da mistura com 10 peso\% de grafite, conforme Figura 5. 


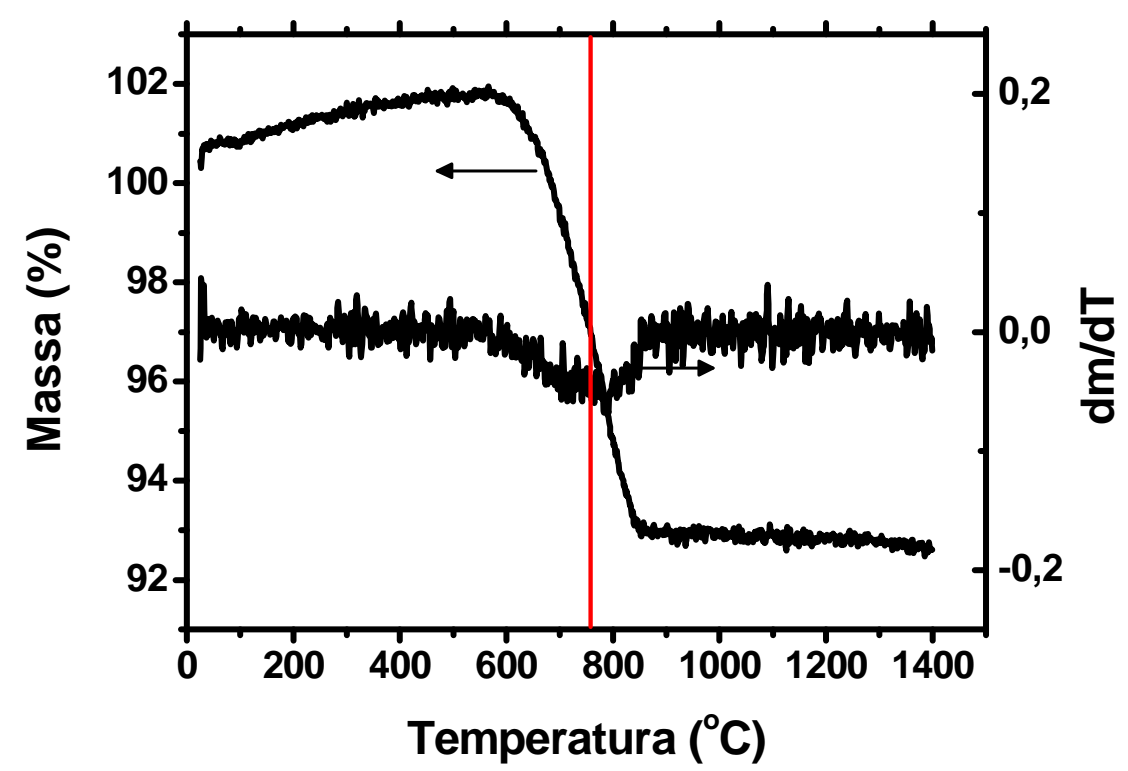

Figura 5 - Curva termogravimétrica e derivada de $\mathrm{ZrO}_{2}: 8$ mol\% $\mathrm{Y}_{2} \mathrm{O}_{3}+10$ peso\% de grafite. A reta vertical indica a temperatura de máxima perda de massa.

Ao ajustar uma curva à derivada obteve-se o valor de $\sim 750{ }^{\circ} \mathrm{C}$ para a temperatura de máxima perda de massa.

Para estudar a retração da amostra durante o tratamento térmico de sinterização, foram feitas análises de dilatometria nos compactos a verde das diferentes misturas. Os resultados estão ilustrados nas Figuras $6 \mathrm{a}, 6 \mathrm{~b}$, e $6 \mathrm{c}$ para zircônia:ítria com adição de iodeto de potássio, cloreto de sódio e grafite, respectivamente. 

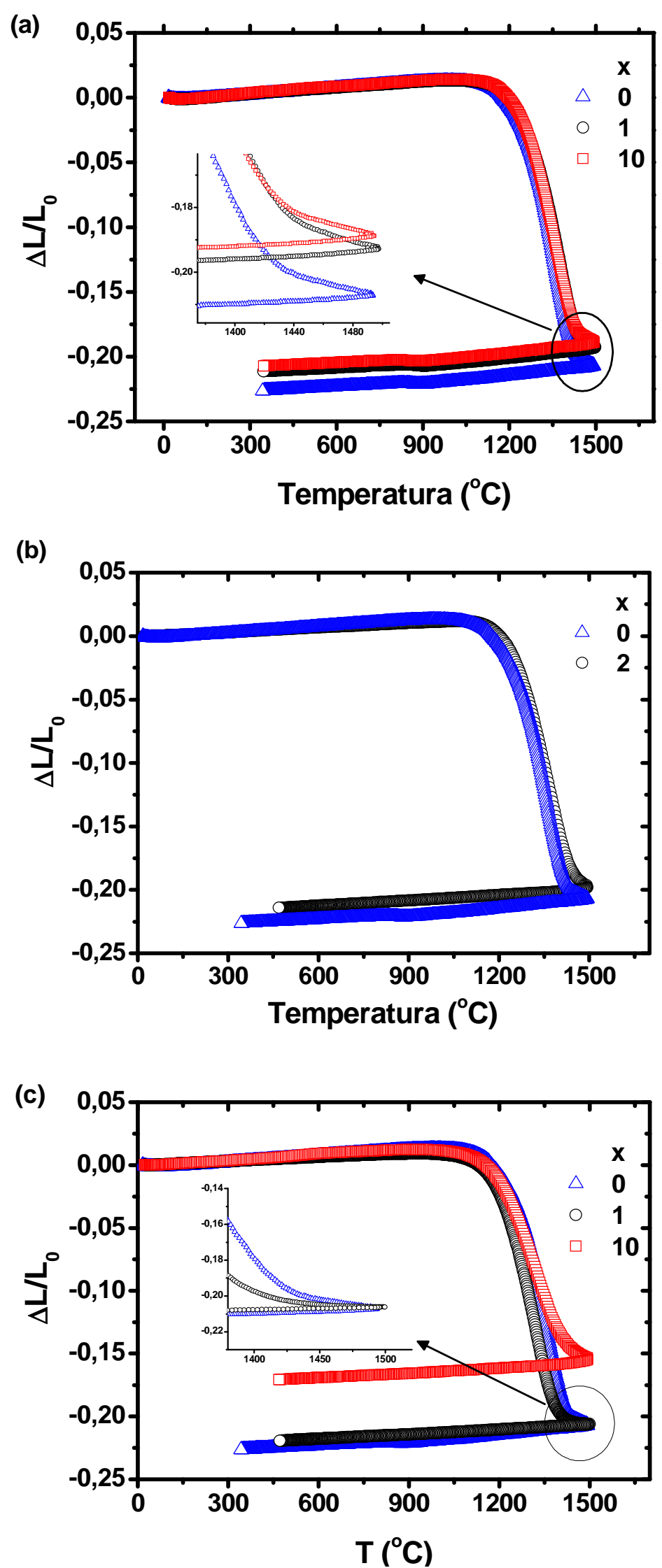

Figura 6 - Curvas de dilatometria de $\mathrm{ZrO}_{2}: 8 \mathrm{~mol} \% \mathrm{Y}_{2} \mathrm{O}_{3}+\mathrm{x}$ peso\% de (A) $\mathrm{KI}$, (B) $\mathrm{NaCl}$ e (C) grafite. A flecha indica um zoom da região entre 1380 e 1500 ○C. 
Quanto maior a porcentagem do aditivo na amostra, menor o valor da retração. A diminuição da retração pode estar relacionada com a diminuição do coeficiente de difusão das vacâncias de oxigênio na região intergranular, pela presença do aditivo nos estágio iniciais de sinterização e pela formação de poros.

As análises de fluorescência de raios $X$ nas amostras antes da sinterização apresentaram as concentrações de iodeto de potássio e cloreto de sódio dispostas na Tabela 2. Tabela 2 - Teor de iodeto de potássio e cloreto de sódio nas amostras de $\mathrm{ZrO}_{2}: 8 \mathrm{~mol} \% \mathrm{Y}_{2} \mathrm{O}_{3}+\mathrm{X}$
peso\% do aditivo, antes da sinterização.

\begin{tabular}{c|cc}
\hline \multirow{2}{*}{$\mathbf{x}$} & \multicolumn{2}{|c}{ Aditivo } \\
& KI (\%) & $\mathbf{N a C l}(\%)$ \\
\hline 0 & 0,0 & 0,0 \\
1 & 1,4 & - \\
10 & 9,4 & 10,0 \\
\hline
\end{tabular}

Após a sinterização das amostras foi feita novamente a análise de fluorescência de raios $\mathrm{X}$ a fim de avaliar o teor residual do aditivo, sendo que os compostos não foram detectados.

Mesmo após a análise por fluorescência de raios $X$ não detectar nenhum resíduo dos halogenetos alcalinos, as amostras foram colocadas em água em ebulição para auxiliar a eliminação de possíveis resíduos remanescentes em poros abertos.

Após este processo foram efetuadas as medidas de densidade. As Figuras 7a, 7b e 7c apresentam os valores obtidos para as densidades relativas para as amostras de zircônia:ítria com adição de iodeto de potássio, cloreto de sódio e grafite, respectivamente. 
(a)

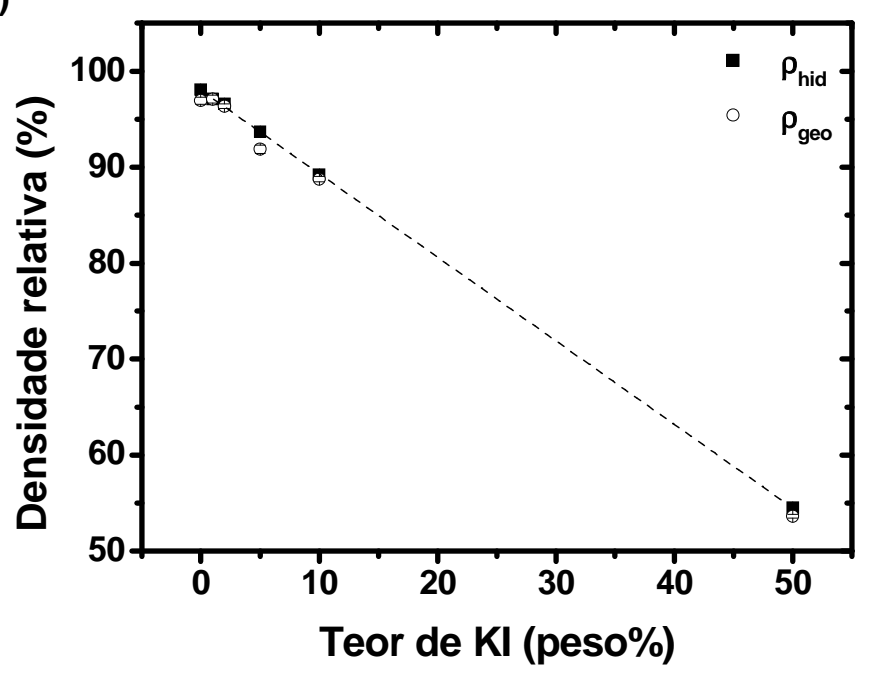

(b)

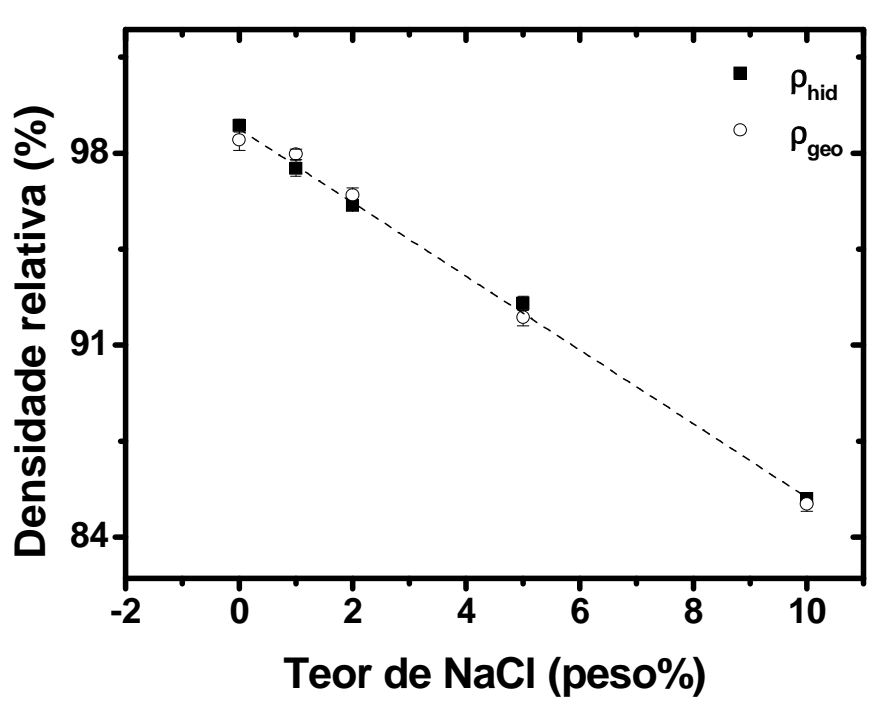

(c)

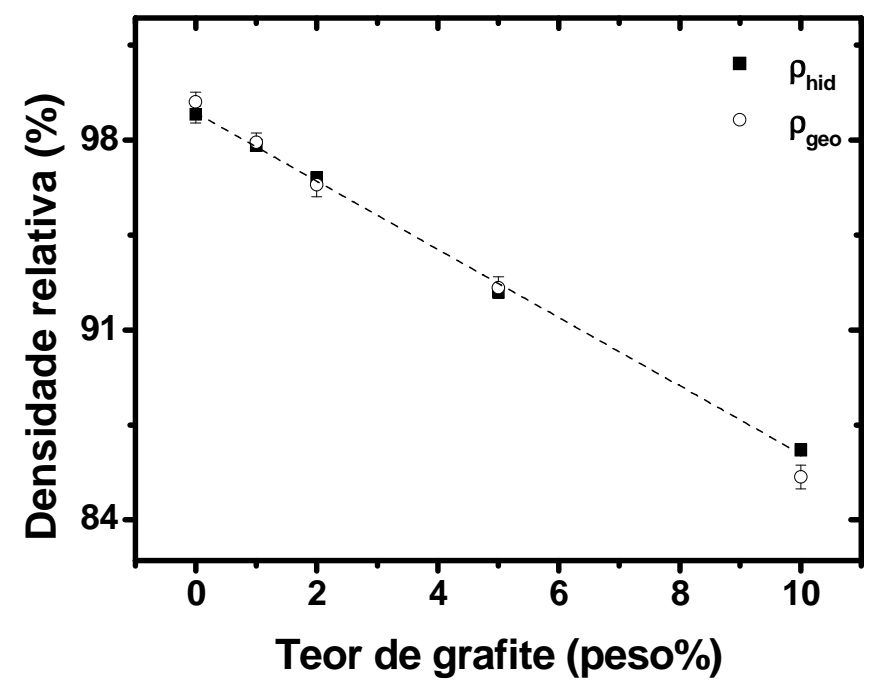

Figura 7 - Densidade relativa de $\mathrm{ZrO}_{2}: 8 \mathrm{~mol} \% \mathrm{Y}_{2} \mathrm{O}_{3}+x$ peso\% de (A) $\mathrm{KI}$, (B) $\mathrm{NaCl}$ e (C) grafite, $x=0,1$, $2,5,10$ e 50 . 
Ao aumentar o teor do aditivo nas misturas, o valor da densidade relativa diminui linearmente. Isso evidencia que o material fica mais poroso à medida que são eliminados os teores crescentes de aditivo. Portanto, é possível controlar a densidade e, consequentemente, a porosidade do material, adicionando teores calculados do aditivo sacrificial.

Após a sinterização foi feita análise por difração de raios $X$ para verificar a fase da zircônia:ítria porosa obtida ao final do processo. Os resultados estão na Figura 8.

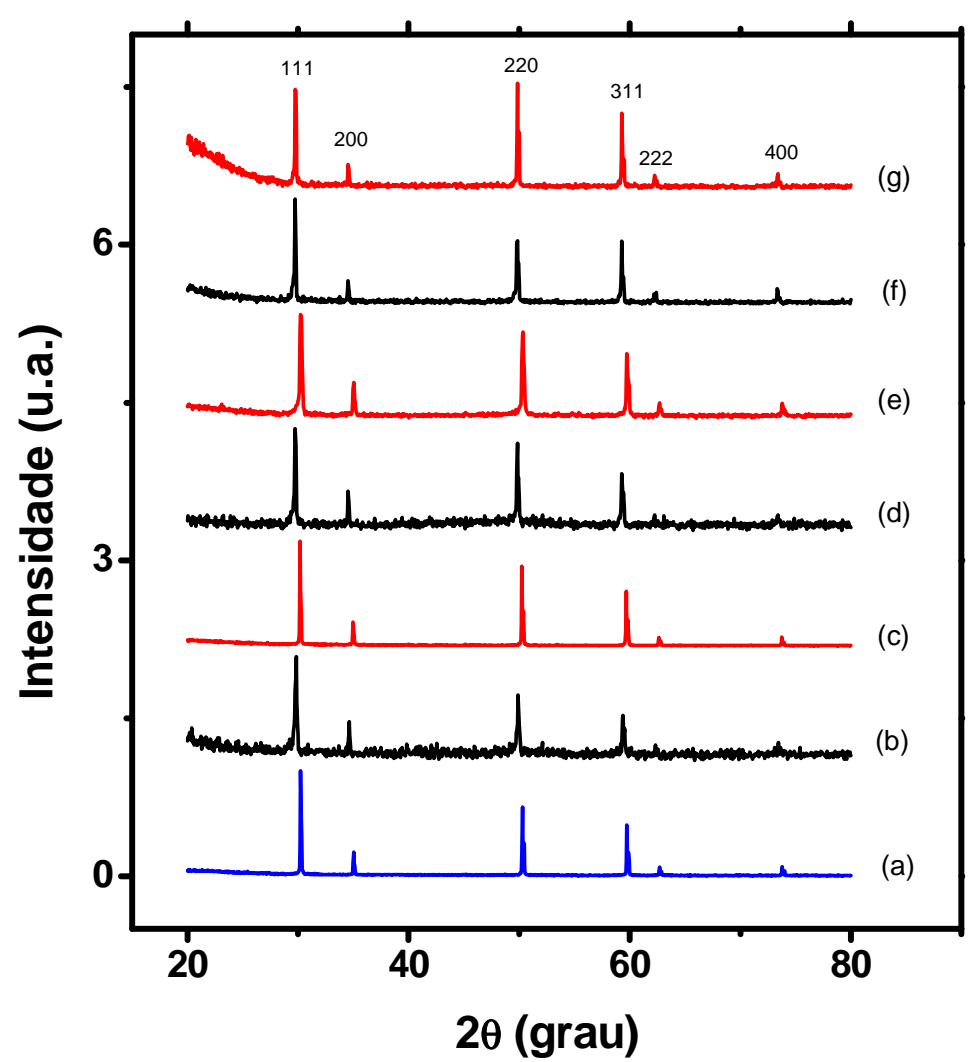

Figura 8 - Difratogramas de raios $\mathrm{X}$ de (a) $\mathrm{ZrO}_{2}: 8$ mol\% $\mathrm{Y}_{2} \mathrm{O}_{3}$, (b) + 1 peso\% $\mathrm{KI}$, (c) + 10 peso\% $\mathrm{KI}$, (d) +1 peso $\% \mathrm{NaCl},(\mathrm{e})+10$ peso $\% \mathrm{NaCl}$, (f) + 1 peso $\%$ grafite e $(\mathrm{g})+10$ peso $\%$ grafite.

A adição dos compostos sacrificiais não modifica a estrutura cristalina do material sinterizado, sendo mantida a fase cúbica tipo fluorita. 


\subsection{Caracterização}

Foram aplicadas duas técnicas para observação da microestrutura das amostras: microscopia de varredura por sonda, no modo força atômica de contato, e microscopia eletrônica de varredura, com o intuito de observar os grãos, avaliar a distribuição de tamanho de grão e verificar o teor de poros das amostras sinterizadas. A Figura 9 mostra as imagens de microscopia eletrônica de varredura (esquerda) e de microscopia de varredura por sonda (direita), obtidas para as amostras com adição de iodeto de potássio.

1a

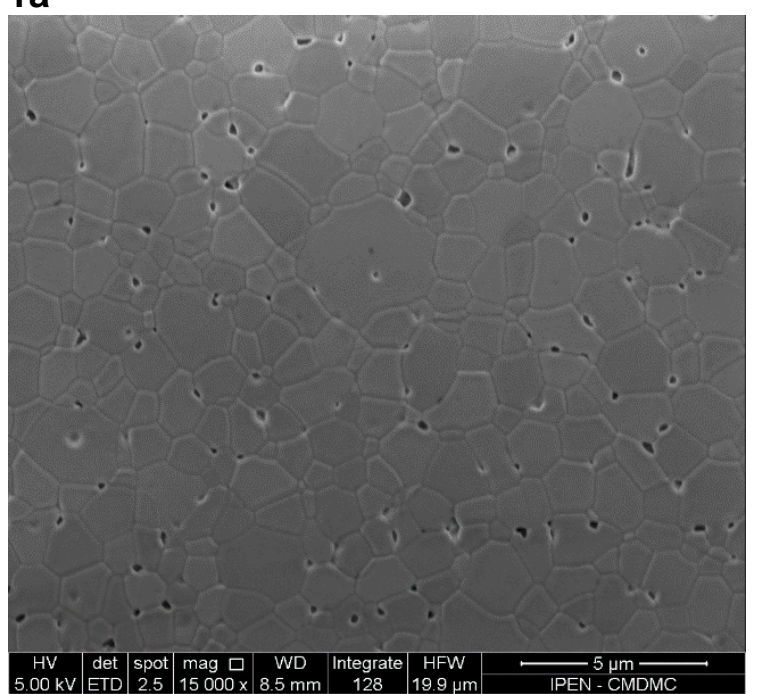

$1 \mathrm{~b}$

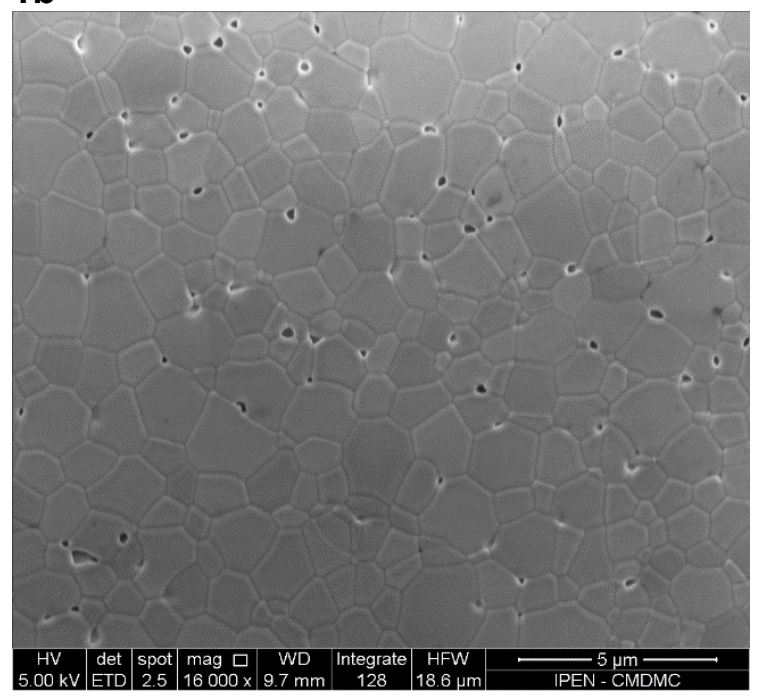

2a

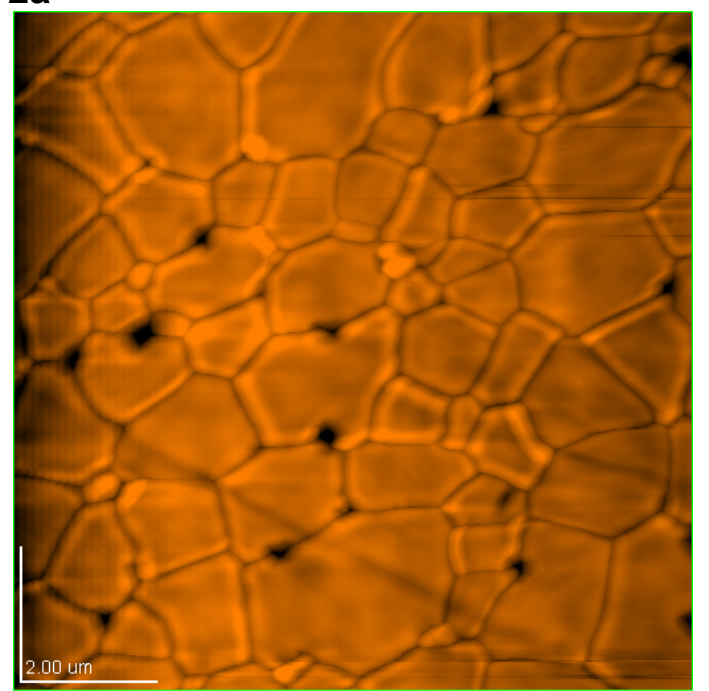

$2 b$

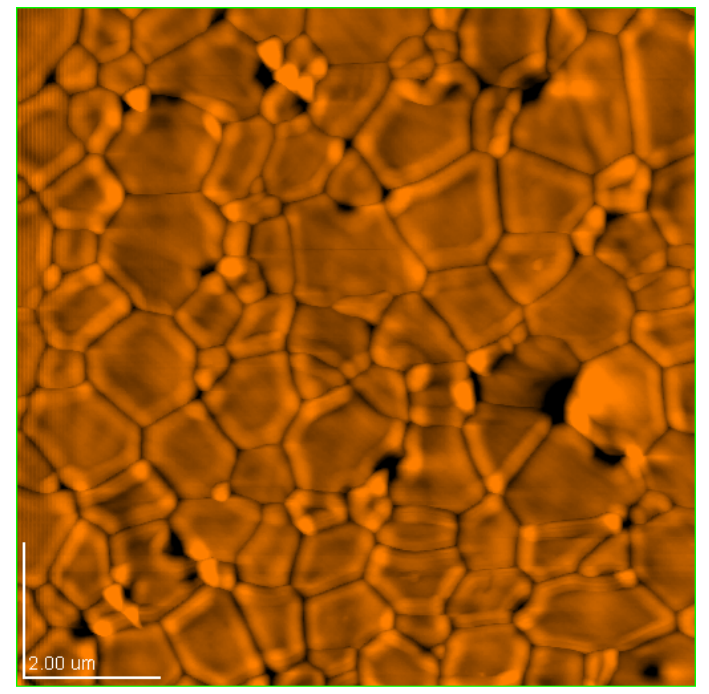


$1 c$

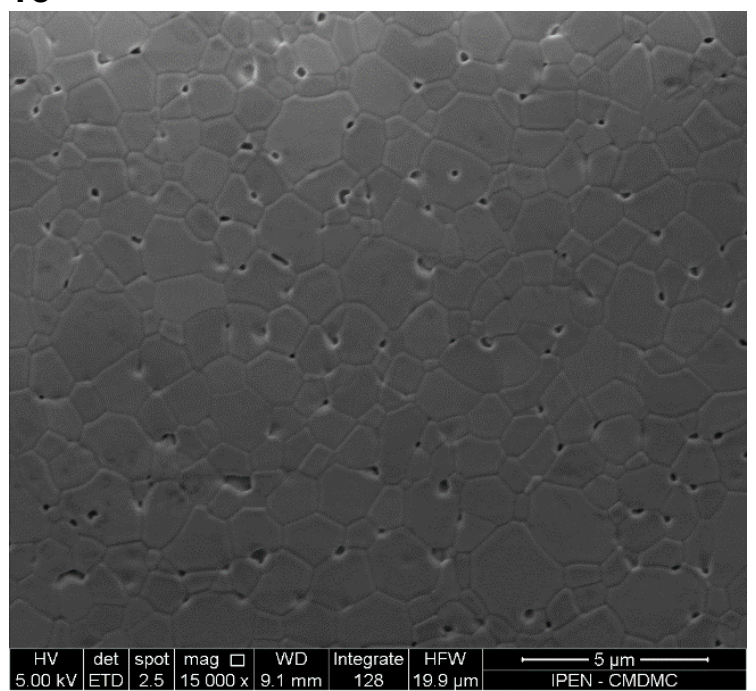

1d

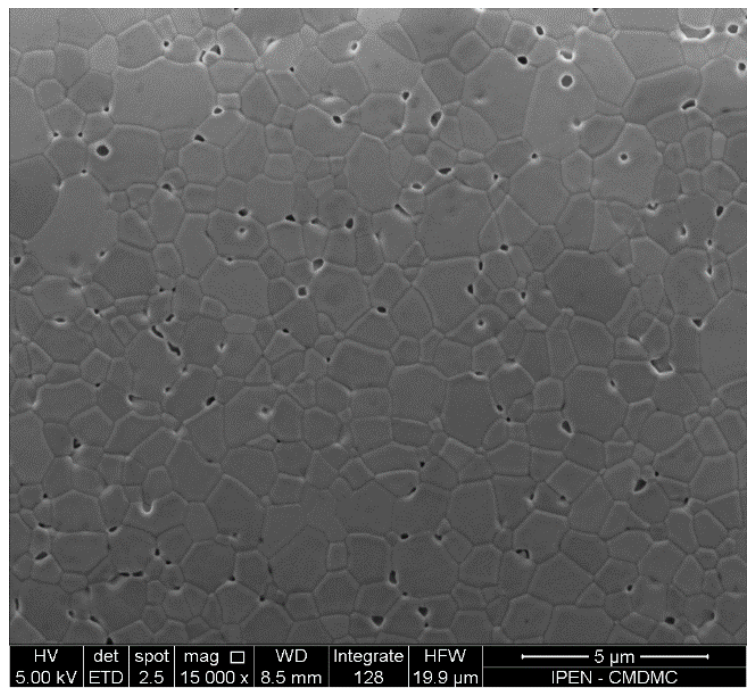

$1 \mathrm{e}$

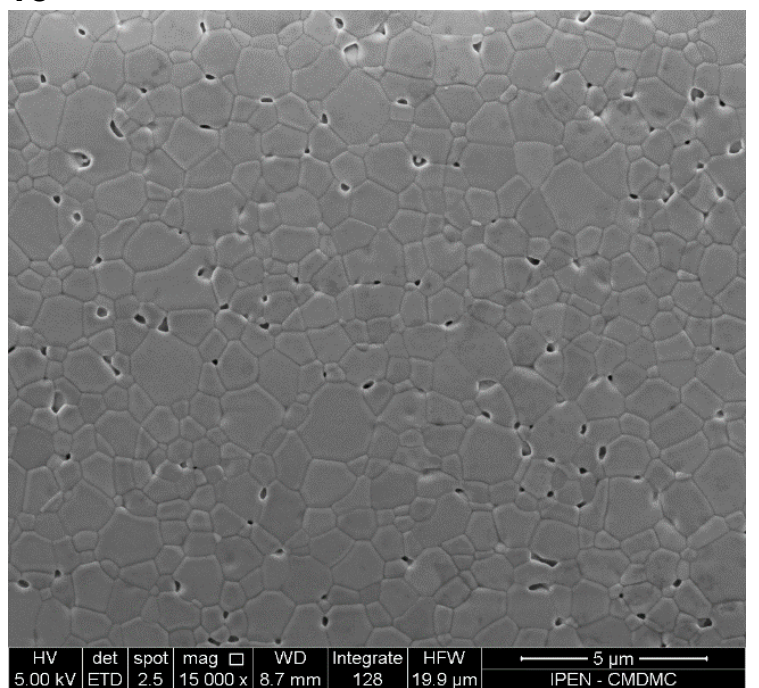

2c

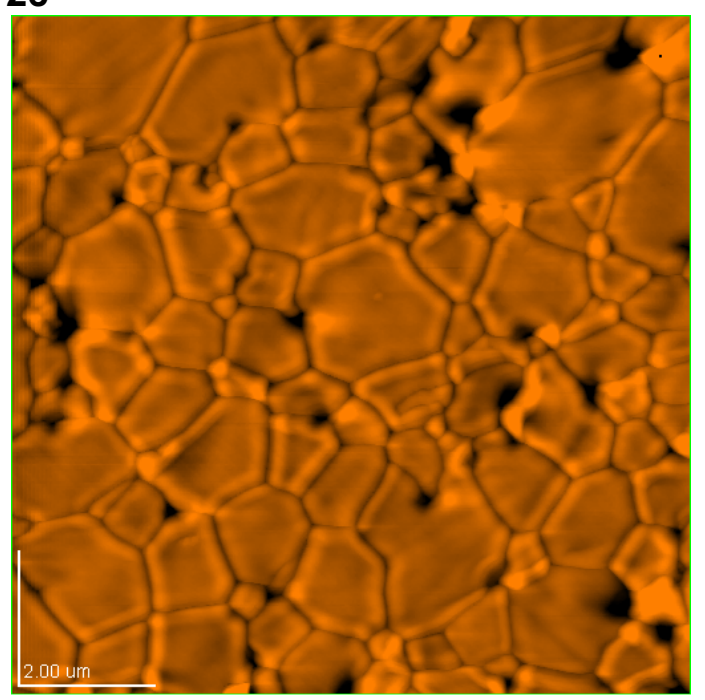

2d

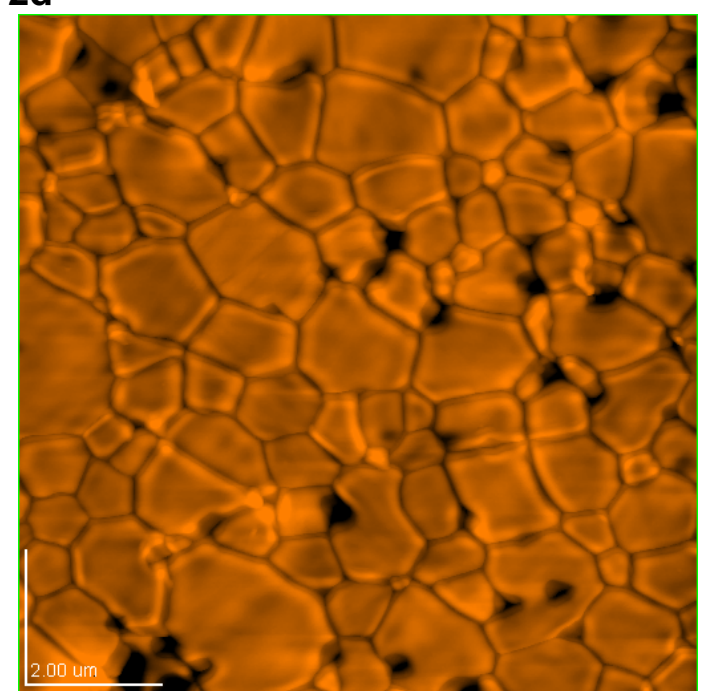

$2 e$

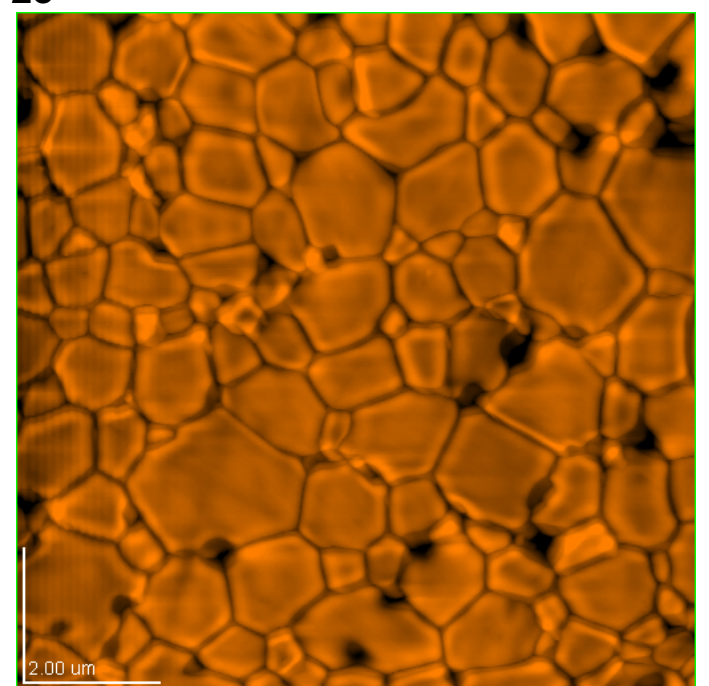

Figura 9 - Micrografias obtidas por microscopia eletrônica de varredura (1) e por microscopia de varredura por sonda (2) de $\mathrm{ZrO}_{2}: 8$ mol\% $\mathrm{Y}_{2} \mathrm{O}_{3}+\mathrm{x}$ peso\% de KI, $\mathrm{x}=0$ (a), 1 (b), 2 (c), 5 (d), 10 (e). 
A amostra sem adição de iodeto de potássio se apresenta densa, com poucos poros. O aumento do teor do aditivo provoca aumento na porosidade intergranular da amostra e tendência de diminuição do tamanho médio de grãos. As imagens obtidas por microscopia de varredura por sonda permitem melhor visualização dos contornos de grão e dos poros. A Tabela 3 apresenta os valores de tamanho médio de grão (G) determinado pelo método de Mendelson ${ }^{[37]}$, aplicado às imagens da Figura 8 obtidas por microscopia eletrônica de varredura. Os resultados concordam com os resultados obtidos pelas imagens de microscopia de varredura por sonda. DV é o desvio padrão e mede a dispersão no tamanho médio de grão.

\footnotetext{
Tabela 3 - Tamanho médio de grão (G) das amostras sinterizadas de $\mathrm{ZrO}_{2}: 8$ mol\% $\mathrm{Y}_{2} \mathrm{O}_{3}$ para os diferentes teores de iodeto de potássio adicionados. Incerteza representa a dispersão no valor do tamanho médio G.
}

\begin{tabular}{c|c}
\hline $\begin{array}{c}\text { Teor } \\
\text { (peso\%) }\end{array}$ & $\begin{array}{c}\text { G } \pm \text { DV } \\
(\boldsymbol{\mu m})\end{array}$ \\
\hline 0 & $1,46 \pm 0,46$ \\
1 & $1,45 \pm 0,42$ \\
2 & $1,24 \pm 0,40$ \\
5 & $1,31 \pm 0,41$ \\
10 & $1,19 \pm 0,39$ \\
50 & $1,14 \pm 0,34$ \\
\hline
\end{tabular}

Houve pequena diminuição do tamanho médio de grão com o aumento de teor de iodeto de potássio adicionado, porém esse aumento pode ser desprezado levando em consideração o desvio padrão estatístico das medidas. A Figura 10 apresenta os histogramas de distribuição do tamanho de grão para as amostras de zircônia:ítria com adição de iodeto de potássio. 
(a)

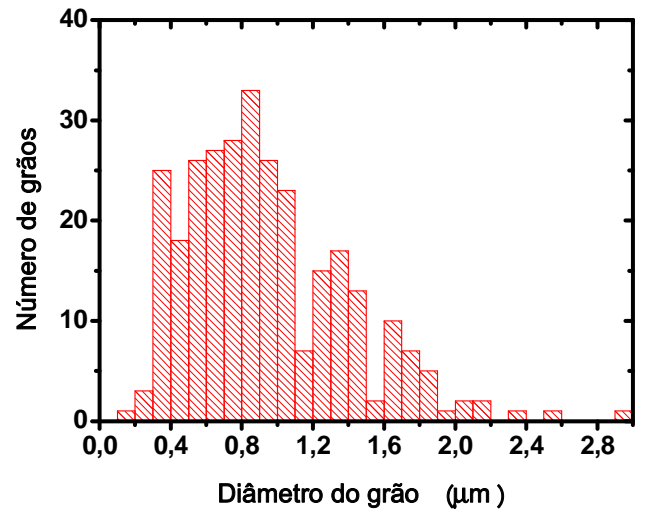

(c)

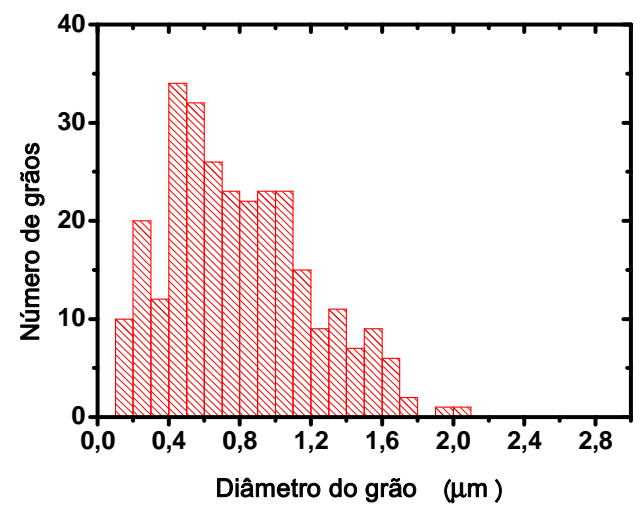

(e)

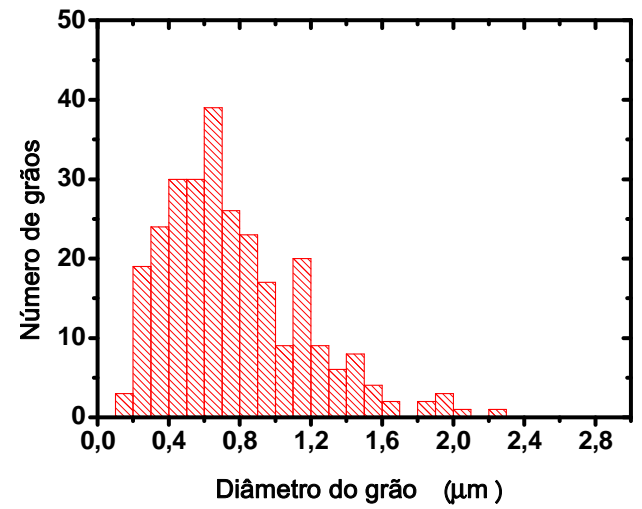

(b)

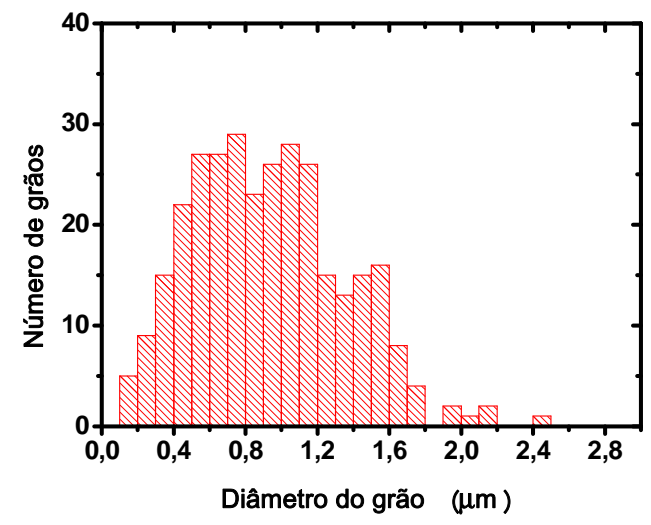

(d)

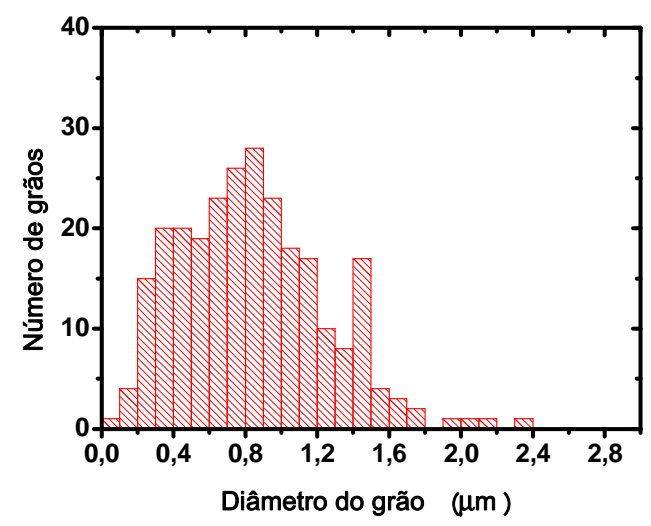

(f)

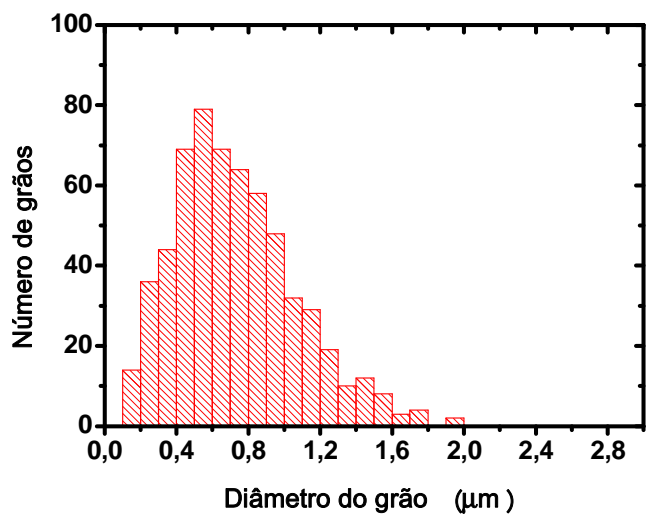

Figura 10 - Histogramas de distribuição de tamanhos de grãos de amostras sinterizadas de $\mathrm{ZrO}_{2}: 8$ mol\% $\mathrm{Y}_{2} \mathrm{O}_{3}+\mathrm{x}$ peso\% de iodeto de potássio como aditivo sacrificial, sendo $x=0$ (a), 1 (b), 2 (c), 5 (d) , 10 (e) e 50 (f).

As amostras apresentam distribuição unimodal do diâmetro do grão, não tendo sido observado crescimento exagerado de grãos devido ao aditivo.

Para análise da porosidade foram utilizadas imagens com um aumento menor (200x) para melhorar a estatística da análise. Com o programa computacional ImageJ, 
essas imagens foram abertas, cortadas a parte inferior onde aparecem as informações da imagem, e em seguida, feito um ajuste chamado threshold que seleciona os pixels da imagem de acordo com sua coloração. Esta seleção pode ser determinada pelo usuário a fim de cobrir todos os poros da amostra. Após a seleção dos poros, é determinada a área percentual selecionada da imagem. A Figura 11 ilustra uma parte do processo efetuado.
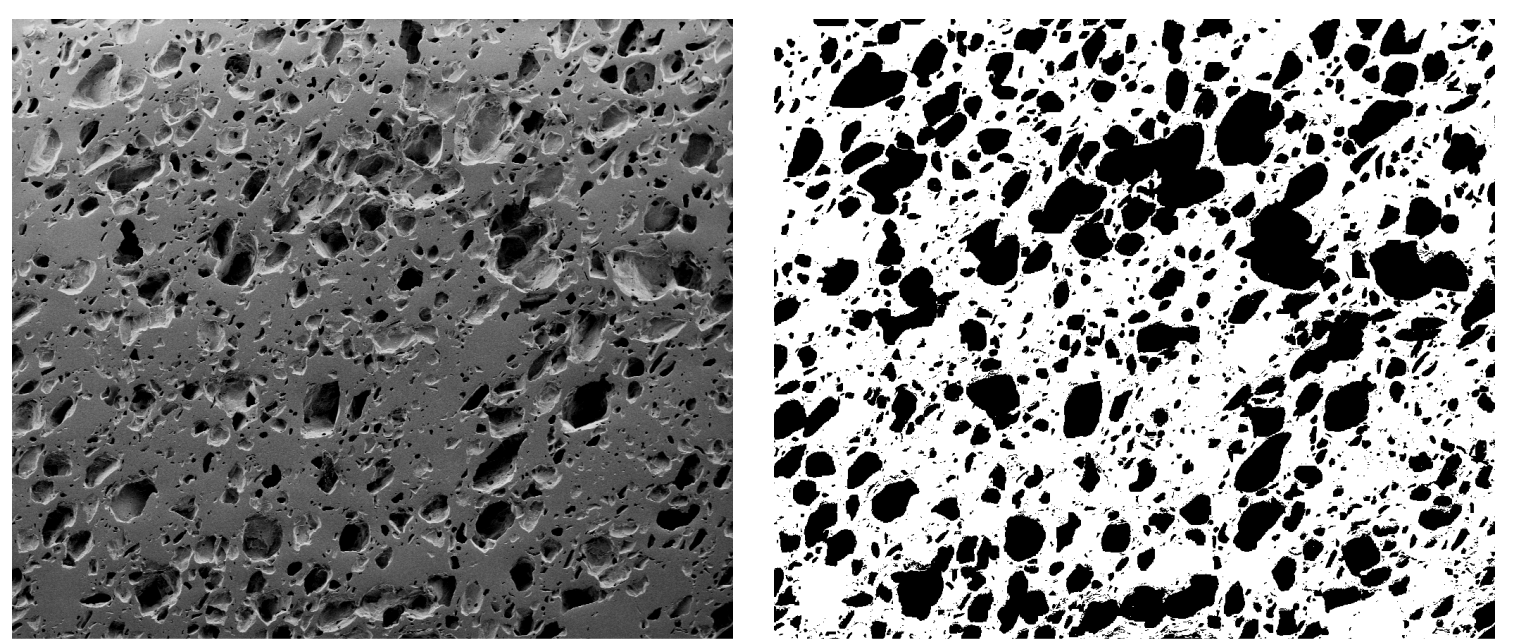

Figura 11 - Micrografias de $\mathrm{ZrO}_{2}: 8 \mathrm{~mol} \% \mathrm{Y}_{2} \mathrm{O}_{3}+50$ peso\% de KI, com aumento de 200x para análise da porosidade. À esquerda a imagem foi cortada para tirar as informações da medida, e à direita após 0 ajuste threshold.

A Tabela 4 apresenta os valores de porosidade para cada amostra, obtidos por meio do procedimento anteriormente descrito.

Tabela 4 - Porosidade das amostras sinterizadas de $\mathrm{ZrO}_{2}: 8$ mol\% $\mathrm{Y}_{2} \mathrm{O}_{3}$ para os diferentes teores de iodeto de potássio adicionados.

\begin{tabular}{c|c}
\hline $\begin{array}{c}\text { Teor } \\
\text { (peso\%) }\end{array}$ & $\begin{array}{c}\text { Porosidade } \\
(\%)\end{array}$ \\
\hline 0 & 0,4 \\
1 & 0,9 \\
2 & 2,8 \\
5 & 3,2 \\
10 & 7,6 \\
50 & 38,8 \\
\hline
\end{tabular}

Foram feitas análises de porosimetria por intrusão de mercúrio apenas nas amostras de zircônia:ítria com $50 \%$ em peso de iodeto de potássio. O resultado obtido concorda com o valor da porosidade obtido pela técnica de análise de imagem. 
O valor da porosidade do material aumenta com o aumento do teor de iodeto de potássio, conforme esperado. Foi possível estabelecer uma relação linear entre estas duas variáveis, conforme mostra Figura 12.

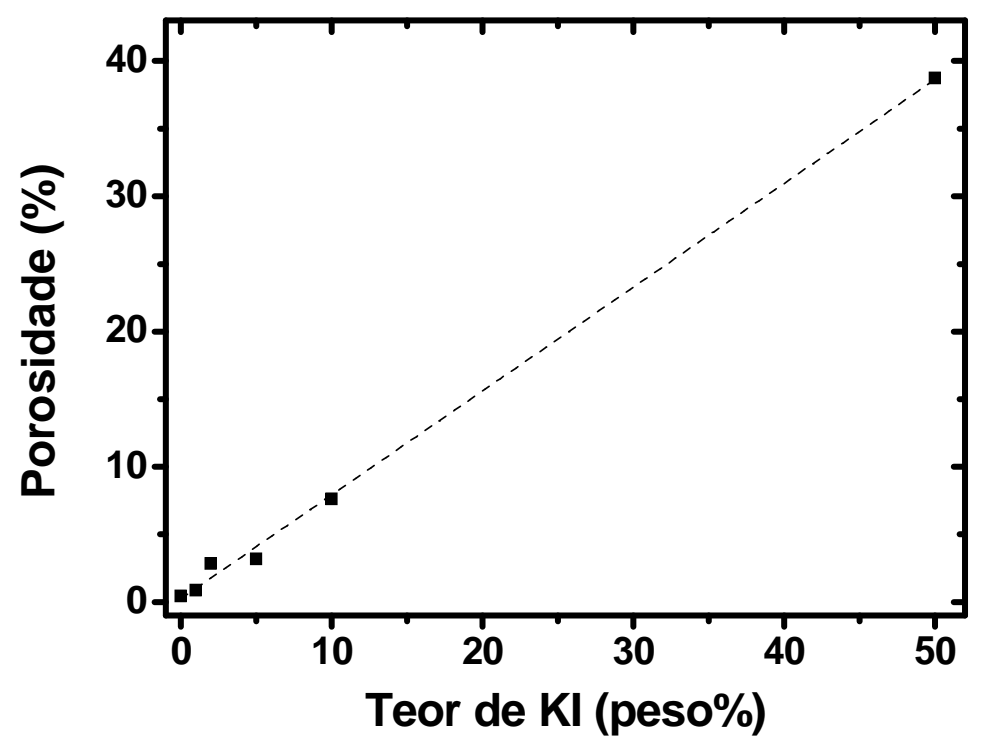

Figura 12 - Porosidade da amostra sinterizadas de $\mathrm{ZrO}_{2}: 8$ mol\% $\mathrm{Y}_{2} \mathrm{O}_{3}$ em função do teor de iodeto de potássio adicionado.

A equação (3.2.1) relaciona a porosidade $(P)$ do material com o teor de iodeto de potássio $\left(\mathrm{X}_{\mathrm{KI}}\right)$ adicionado, conforme a reta pontilhada da Figura 12.

$$
P=0,25+0,77 \cdot X_{K I}
$$

A Figura 13 apresenta as imagens obtidas em microscópio eletrônico de varredura (esquerda) e em microscopia eletrônica de varredura (direita) para as amostras com adição de cloreto de sódio. 
$1 a$

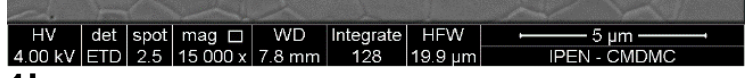

1b

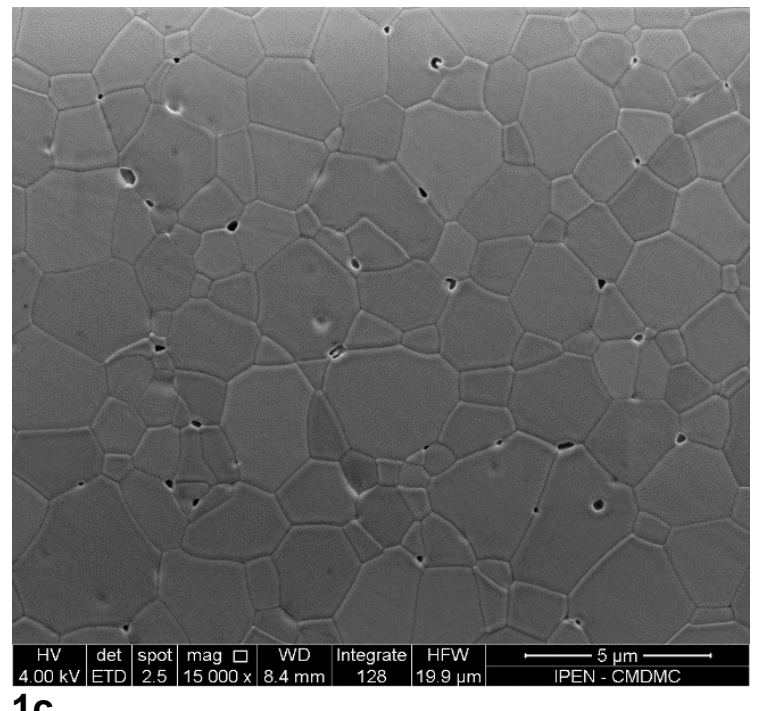

$1 \mathrm{C}$

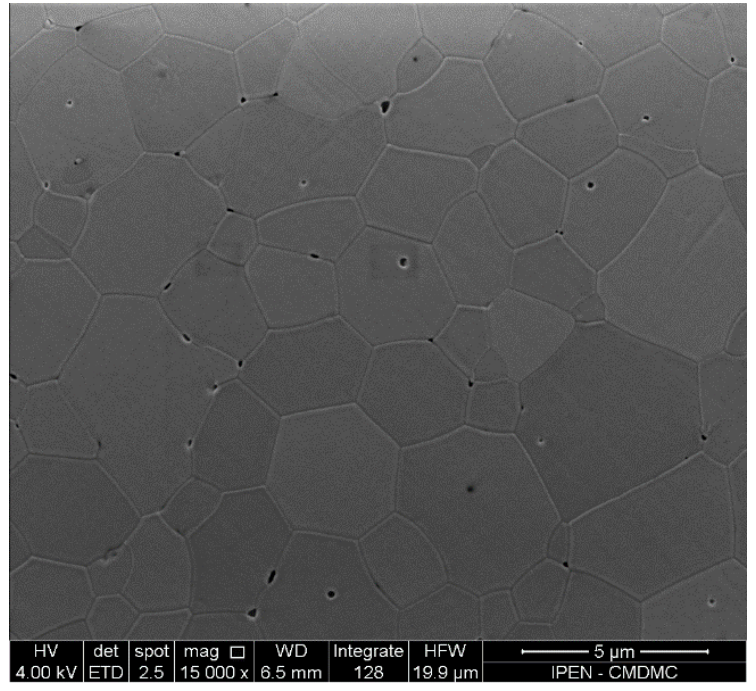

$2 a$

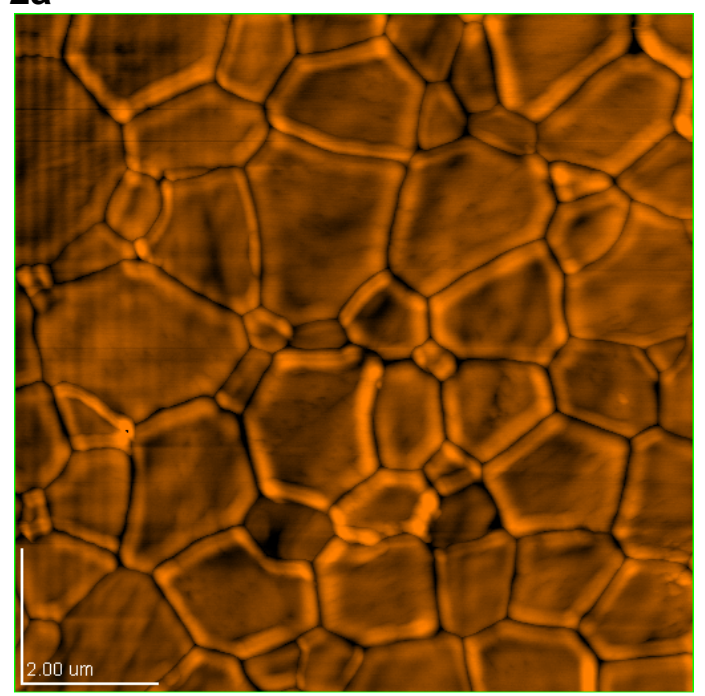

$2 b$

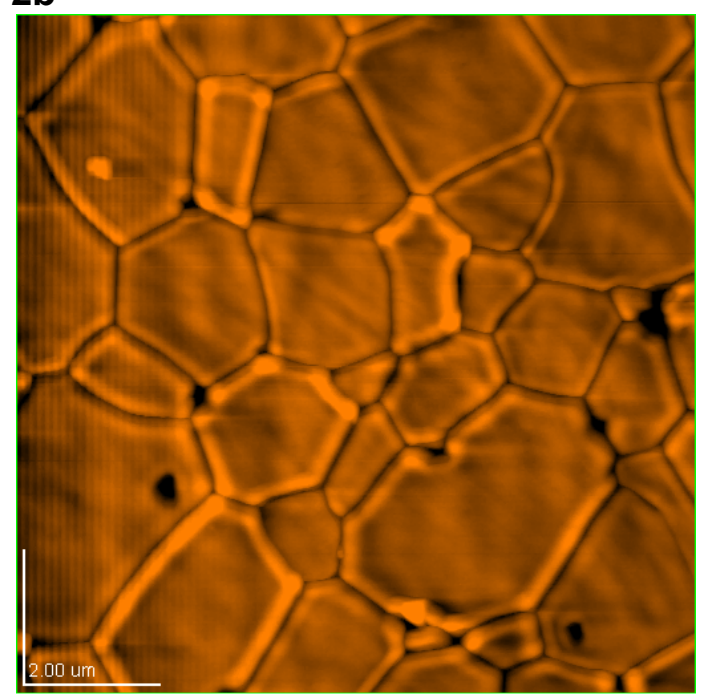

2c

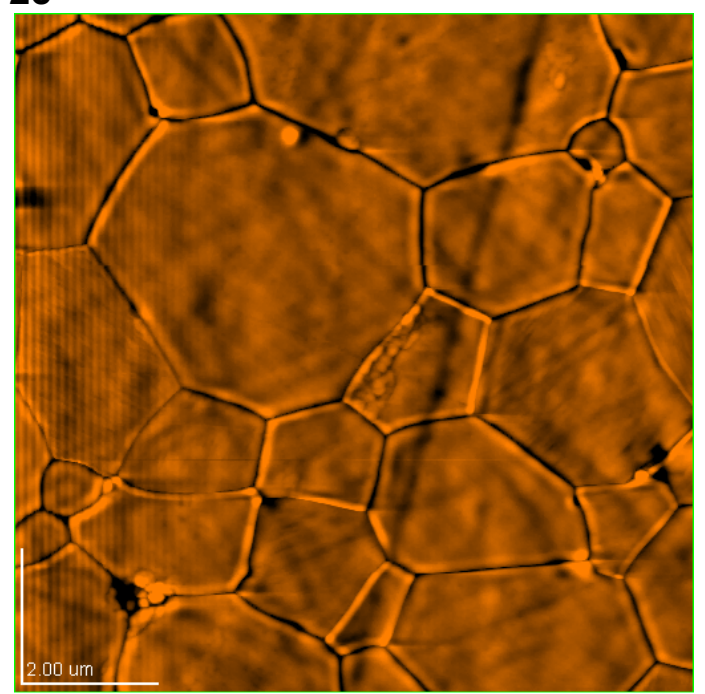


1d

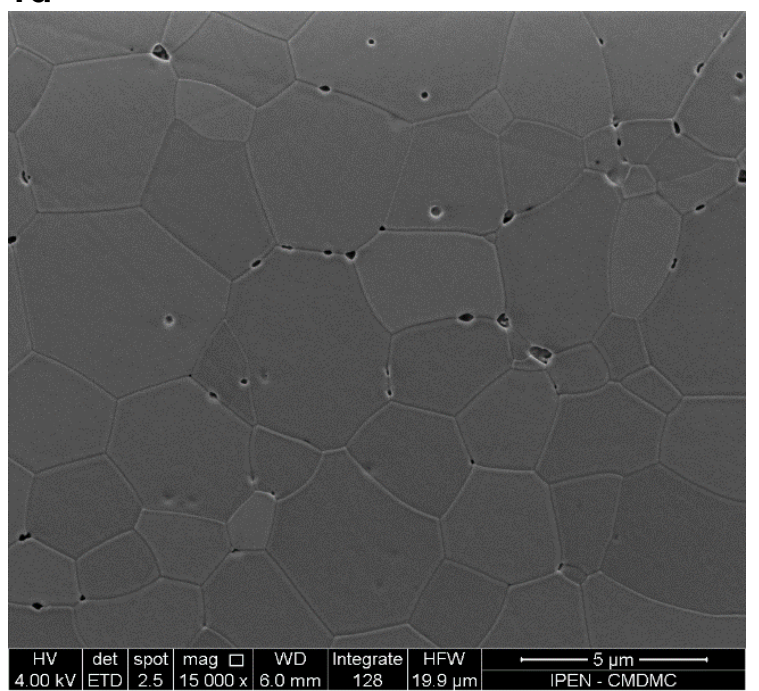

$1 e$

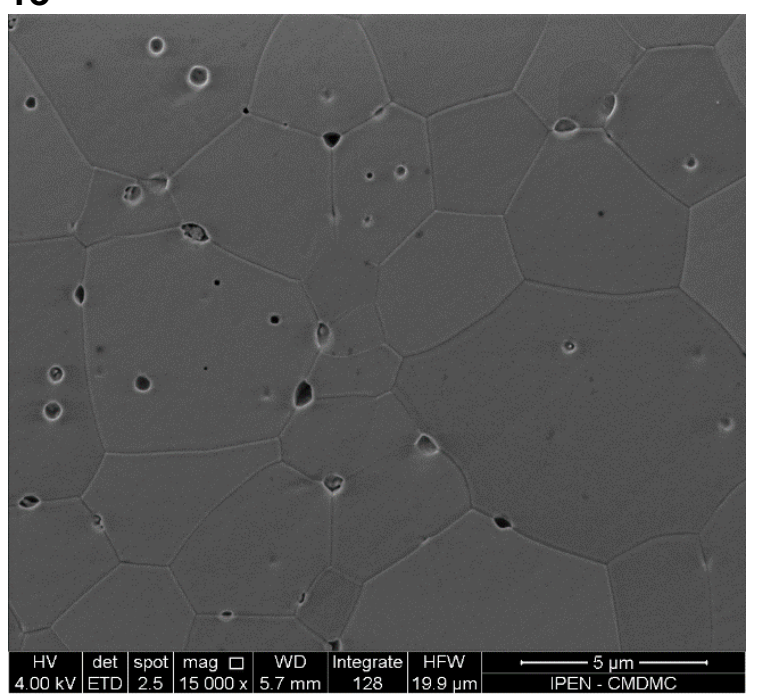

2d

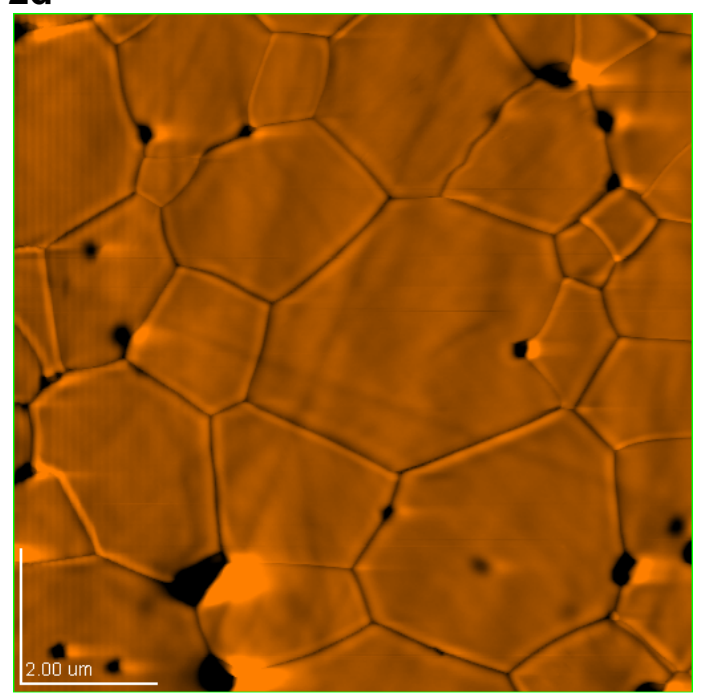

$2 e$

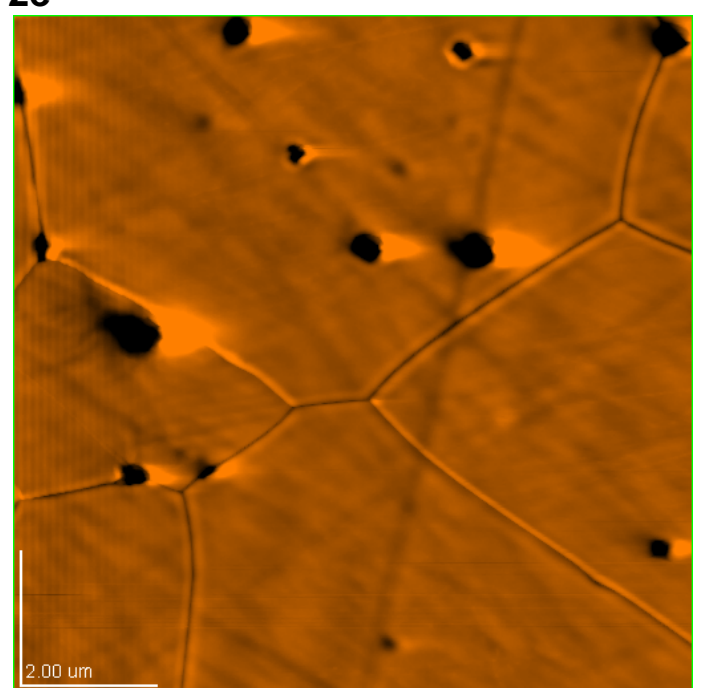

Figura 13 - Micrografias obtidas por microscopia eletrônica de varredura (1) e por microscopia de varredura por sonda (2) de $\mathrm{ZrO}_{2}: 8$ mol\% $\mathrm{Y}_{2} \mathrm{O}_{3}+x$ peso\% de $\mathrm{NaCl}, \mathrm{x}=0$ (a), 1 (b), 2 (c), 5 (d) e 10 (e).

A amostra sem aditivo se apresenta densa, com poucos poros. Pelas imagens de microscopia de varredura por sonda é possível observar que a adição de cloreto de sódio provoca aumento da quantidade de poros intergranulares e o surgimento de poros intragranulares. As imagens obtidas por microscopia de varredura por sonda revelam uma diminuição do tamanho médio de grão com a adição do cloreto de sódio e posterior aumento do tamanho médio de grão com o aumento do teor do aditivo.

A Tabela 5 apresenta os valores de tamanho médio de grão $(G)$ determinado pelo método de Mendelson ${ }^{[35]}$, aplicado às imagens da Figura 13. 
Tabela 5 - Tamanho médio de grão (G) das amostras sinterizadas de $\mathrm{ZrO}_{2}: 8 \mathrm{~mol} \% \mathrm{Y}_{2} \mathrm{O}_{3}$ para os diferentes teores de cloreto de sódio adicionados. DV é o desvio padrão e representa a dispersão no valor do tamanho médio $\mathrm{G}$.

\begin{tabular}{c|c}
\hline $\begin{array}{c}\text { Teor } \\
(\text { peso\%) }\end{array}$ & $\begin{array}{c}\text { G } \pm \text { DV } \\
(\boldsymbol{\mu m})\end{array}$ \\
\hline 0 & $3,08 \pm 1,25$ \\
1 & $2,16 \pm 0,71$ \\
2 & $2,30 \pm 0,84$ \\
5 & $2,82 \pm 0,98$ \\
10 & $4,61 \pm 1,62$ \\
\hline
\end{tabular}

A adição de cloreto de sódio à zircônia:ítria provocou uma diminuição no tamanho médio de grão, que após o aumento do teor de cloreto de sódio adicionado, voltou a aumentar. A Figura 14 apresenta os valores da Tabela 5, de tamanho médio de grão em função do teor de cloreto de sódio.

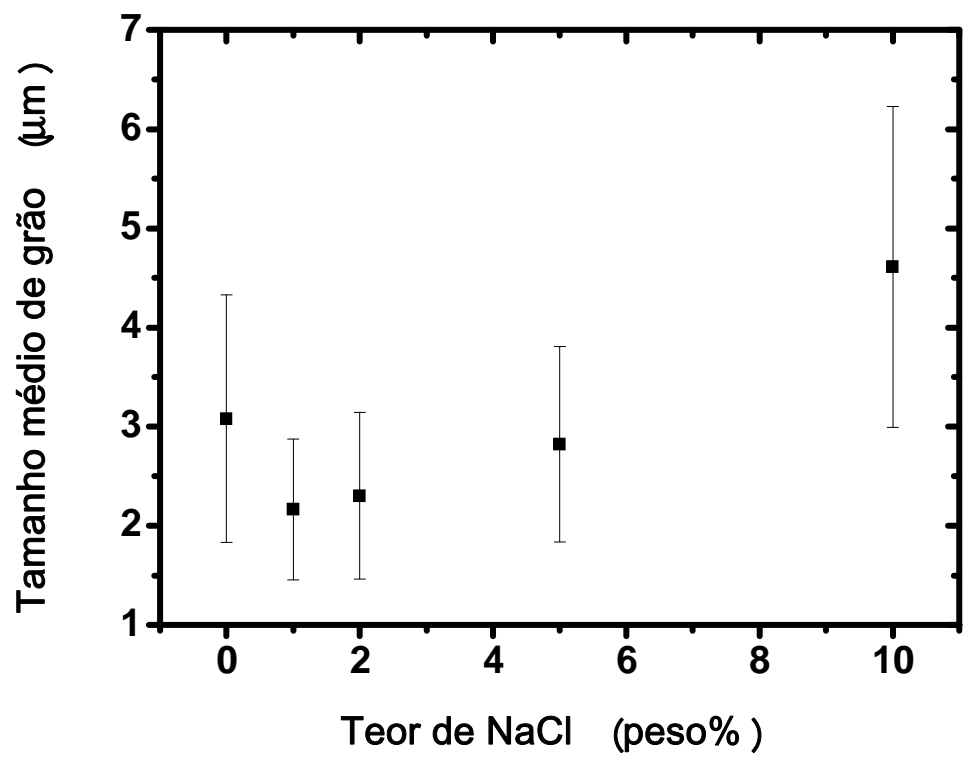

Figura 14 - Tamanho médio de grão das amostras de $\mathrm{ZrO}_{2}: 8$ mol\% $\mathrm{Y}_{2} \mathrm{O}_{3}$ em função do teor de cloreto de sódio adicionado.

Há diminuição no tamanho médio de grão, porém este valor pode ser desprezado considerando o erro nas determinações, isto é, esta diminuição é estatisticamente insignificante. Pode-se considerar o aumento do tamanho médio de grão apenas para a amostra com 10 peso\% de cloreto de sódio.

A Figura 15 apresenta os histogramas de distribuição do tamanho de grão obtidos para as amostras de zircônia:ítria com adição de cloreto de sódio. 
(a)

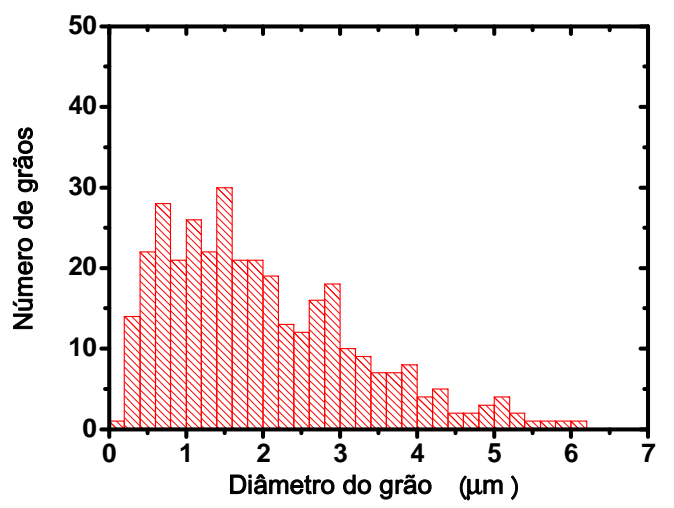

(c)

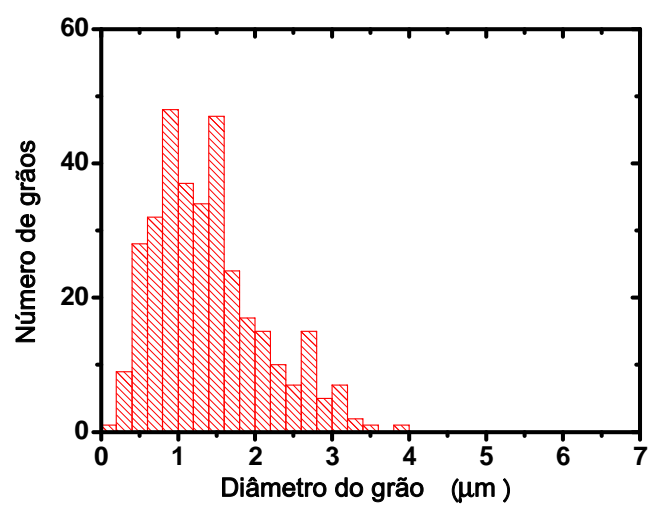

(b)

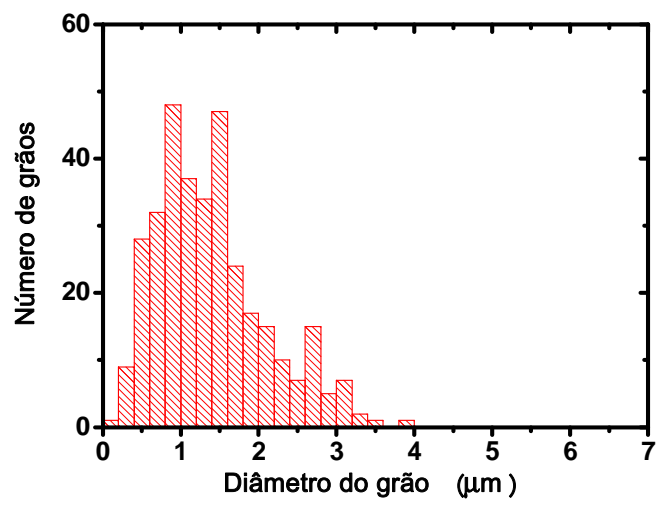

(d)

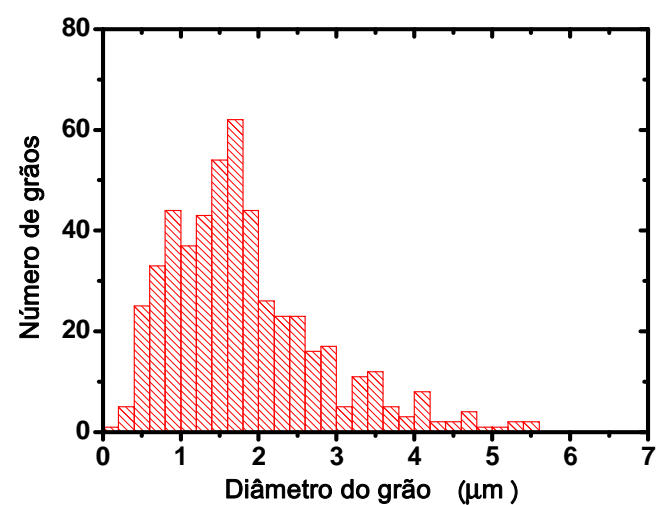

(e)

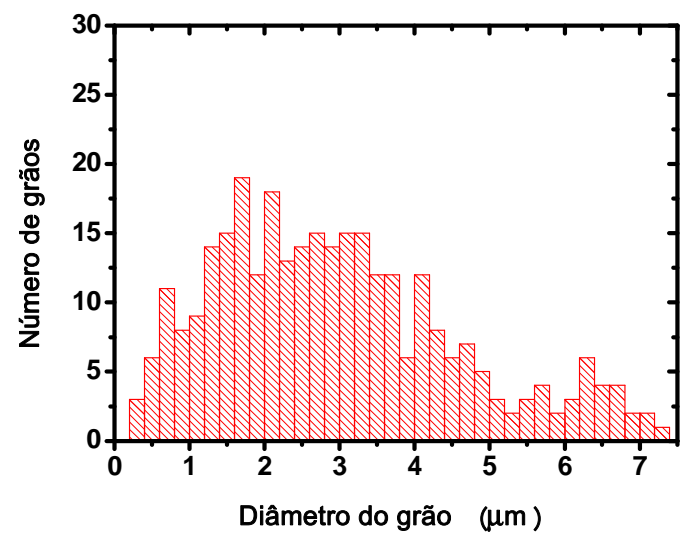

Figura 15 - Histogramas de distribuição de tamanhos de grãos para amostras sinterizadas de $\mathrm{ZrO}_{2}: 8$ mol\% $\mathrm{Y}_{2} \mathrm{O}_{3}+\mathrm{x}$ peso\% de cloreto de sódio como aditivo sacrificial, sendo $x=0$ (a), 1 (b), 2 (c), 5 (d) e 10 (e).

A amostra sem o aditivo (Figura 15a) apresenta histograma disperso, quando comparado com os histogramas das outras amostras; por esse motivo o tamanho médio de grão possui um alto valor, assim como o desvio padrão. Para a amostra com 10 peso\% de cloreto de sódio (Figura 15e) observa-se uma distribuição bimodal, que pode ser ocasionada por um crescimento anormal de grãos. Este crescimento é ocasionado, 
possivelmente, pela presença de cloreto de sódio na fase líquida que facilitou o rearranjo das partículas e crescimento do grão durante o processo de sinterização.

Do mesmo modo como foi feito para os compostos com iodeto de potássio, o cálculo da porosidade das amostras com adição de cloreto de sódio foi feito utilizando micrografias com aumento de 250x e o programa ImageJ. A tabela 6 apresenta os valores obtidos para a porosidade das amostras.

Tabela 6 - Porosidade das amostras sinterizadas de $\mathrm{ZrO}_{2}: 8 \mathrm{~mol} \% \mathrm{Y}_{2} \mathrm{O}_{3}$ para os diferentes teores de cloreto de sódio adicionados.

\begin{tabular}{c|c}
\hline $\begin{array}{c}\text { Teor } \\
\text { (peso\%) }\end{array}$ & $\begin{array}{c}\text { Porosidade } \\
(\%)\end{array}$ \\
\hline 0 & 0,0 \\
1 & 0,9 \\
2 & 4,1 \\
5 & 5,2 \\
10 & 8,2 \\
\hline
\end{tabular}

O valor da porosidade aumenta com o aumento do teor de cloreto de sódio adicionado, conforme esperado. Quando comparado com as amostras obtidas pela adição do $\mathrm{KI}$, para o $\mathrm{NaCl}$ é possível obter uma porosidade maior com o mesmo teor de aditivo. Isso ocorre, pois a sua densidade é menor que a do KI, apresentando, portanto, um maior volume.

Foi possível estabelecer uma relação linear entre a porosidade e o teor do aditivo conforme mostra Figura 16. 


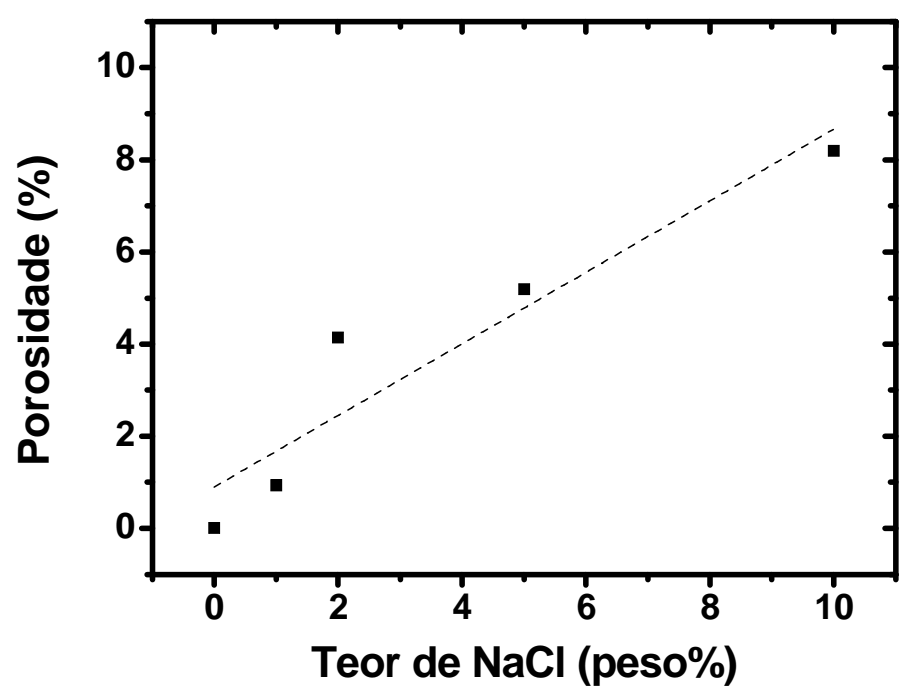

Figura 16 - Porosidade da amostra sinterizada de $\mathrm{ZrO}_{2}: 8$ mol\% $\mathrm{Y}_{2} \mathrm{O}_{3}$ em função do teor de cloreto de sódio adicionado.

A equação (3.2.2) relaciona a porosidade $(P)$ do material com o teor de cloreto de sódio $\left(\mathrm{X}_{\mathrm{NaCl}}\right)$ adicionado, conforme a reta pontilhada da Figura 16.

$$
P=0,90+0,78 . X_{N a C l}
$$

O mesmo procedimento de cálculo do tamanho médio de grão e da porosidade foi feito para as amostras sinterizadas com adição de grafite, com o intuito de comparação. A Figura 17 apresenta as imagens obtidas por microscopia eletrônica de varredura, de zircônia:ítria sinterizada com diferentes teores de grafite. 

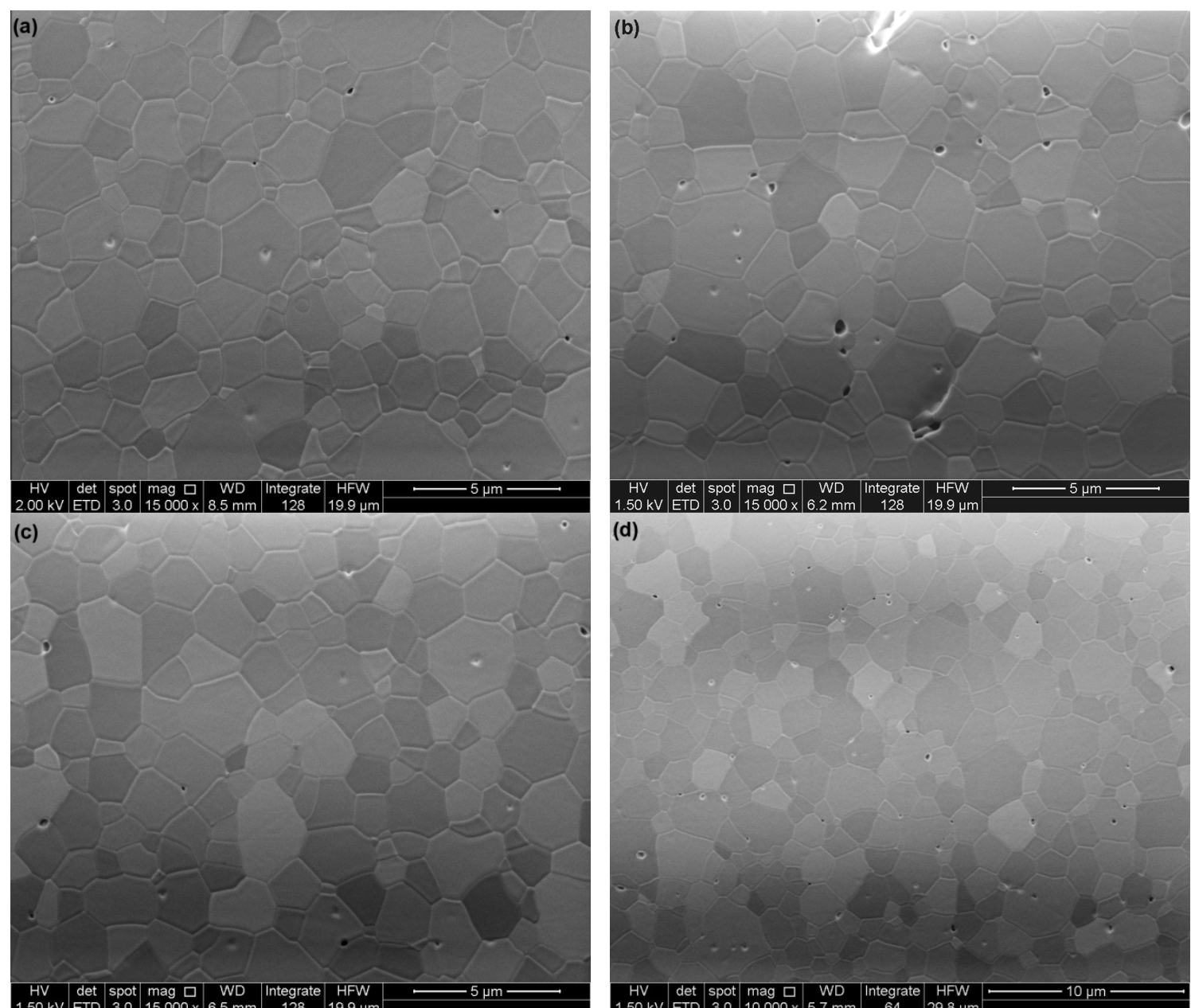

(d)

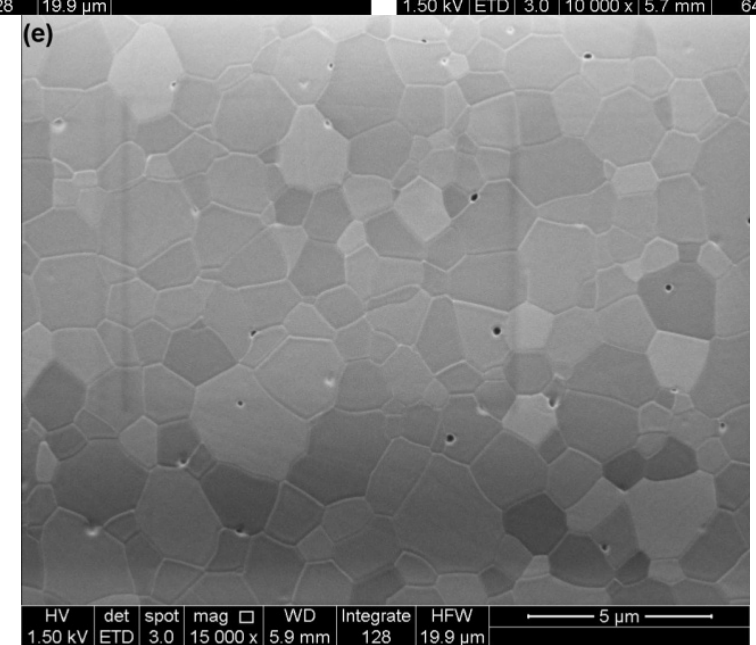

Figura 17 - Micrografias obtidas por microscopia eletrônica de varredura de $\mathrm{ZrO}_{2}: 8 \mathrm{~mol}_{\%} \mathrm{Y}_{2} \mathrm{O}_{3}+\mathrm{X}$ peso\% de grafite, $x=0$ (a), 1 (b), 2 (c), 5 (d) e 10 (e).

As amostras se apresentam densas, com tendência de aumento pouco significativo do tamanho médio de grãos com o aumento de teor de grafite. A densidade de poros também aumenta com o teor de grafite, porém é mais visível para micrografias com aumentos menores.

A Tabela 7 apresenta os valores de tamanho médio de grão (G) determinados pelo método de Mendelson ${ }^{[35]}$, aplicado às imagens da Figura 18. 
Tabela 7 - Tamanho médio de grão (G) das amostras sinterizadas de $\mathrm{ZrO}_{2}: 8$ mol\% $\mathrm{Y}_{2} \mathrm{O}_{3}$ para os diferentes teores de grafite adicionados. DV é o desvio padrão e representa a dispersão no valor do tamanho médio G.

\begin{tabular}{c|c}
\hline $\begin{array}{c}\text { Teor } \\
(\text { peso\%) }\end{array}$ & $\begin{array}{c}\text { G } \pm \text { DV } \\
(\boldsymbol{\mu m})\end{array}$ \\
\hline 0 & $1,67 \pm 0,60$ \\
1 & $1,93 \pm 0,58$ \\
2 & $1,89 \pm 0,55$ \\
5 & $1,99 \pm 0,68$ \\
10 & $1,75 \pm 0,59$ \\
\hline
\end{tabular}

Há uma pequena variação no tamanho médio de grão do compacto sinterizado. A Figura 18 apresenta os histogramas de distribuição do tamanho de grão obtidos para as amostras com adição de grafite como formador de poro.

(a)

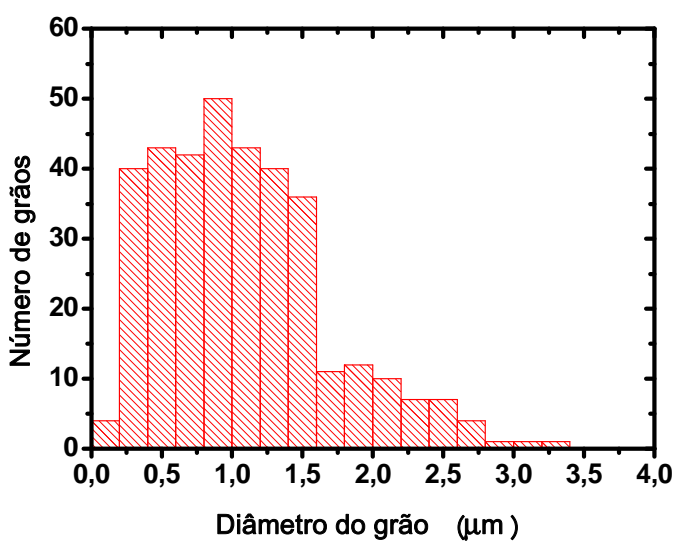

(c)

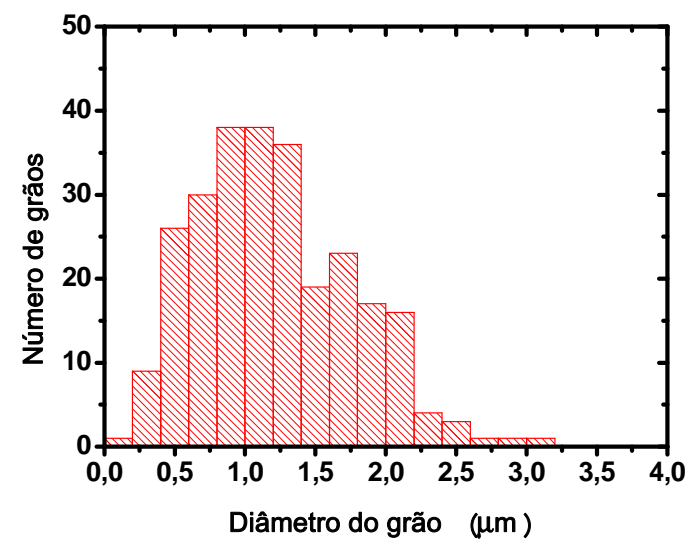

(b)

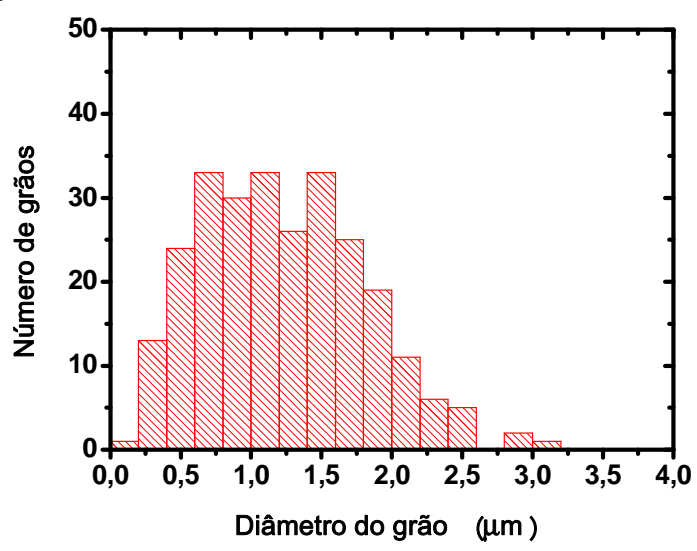

(d)

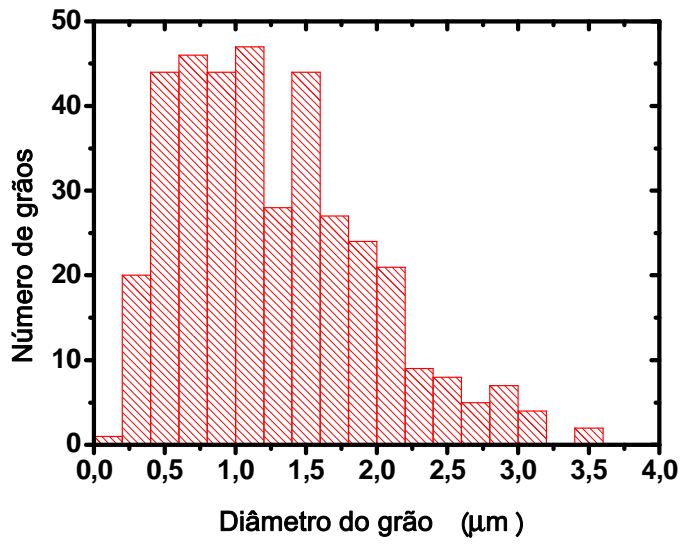


(e)

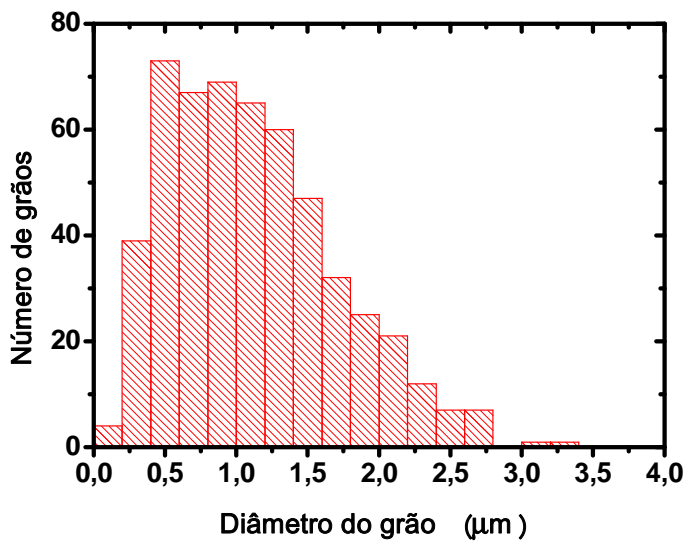

Figura 18 - Histogramas de distribuição de tamanhos de grãos de amostras sinterizadas de $\mathrm{ZrO}_{2}: 8$ mol\% $\mathrm{Y}_{2} \mathrm{O}_{3}+\mathrm{x}$ peso\% de grafite como aditivo sacrificial, sendo $x=0$ (a), 1 (b), 2 (c), 5 (d) e 10 (e).

Para a análise da porosidade foram utilizadas micrografias com aumento de 200x.O valor da porosidade obtido está apresentado na Tabela 8.

Tabela 8 - Porosidade das amostras sinterizadas de $\mathrm{ZrO}_{2}: 8 \mathrm{~mol} \% \mathrm{Y}_{2} \mathrm{O}_{3}$ para os diferentes teores de grafite adicionados.

\begin{tabular}{c|c}
\hline $\begin{array}{c}\text { Teor } \\
\text { (peso\%) }\end{array}$ & $\begin{array}{c}\text { Porosidade } \\
(\%)\end{array}$ \\
\hline 0 & 0,1 \\
1 & 0,7 \\
2 & 1,0 \\
5 & 3,7 \\
10 & 8,2 \\
\hline
\end{tabular}

O valor da porosidade aumenta linearmente com o teor de grafite adicionadoás amostras de zircônia:ítria. A Figura 19 evidencia esta relação. 


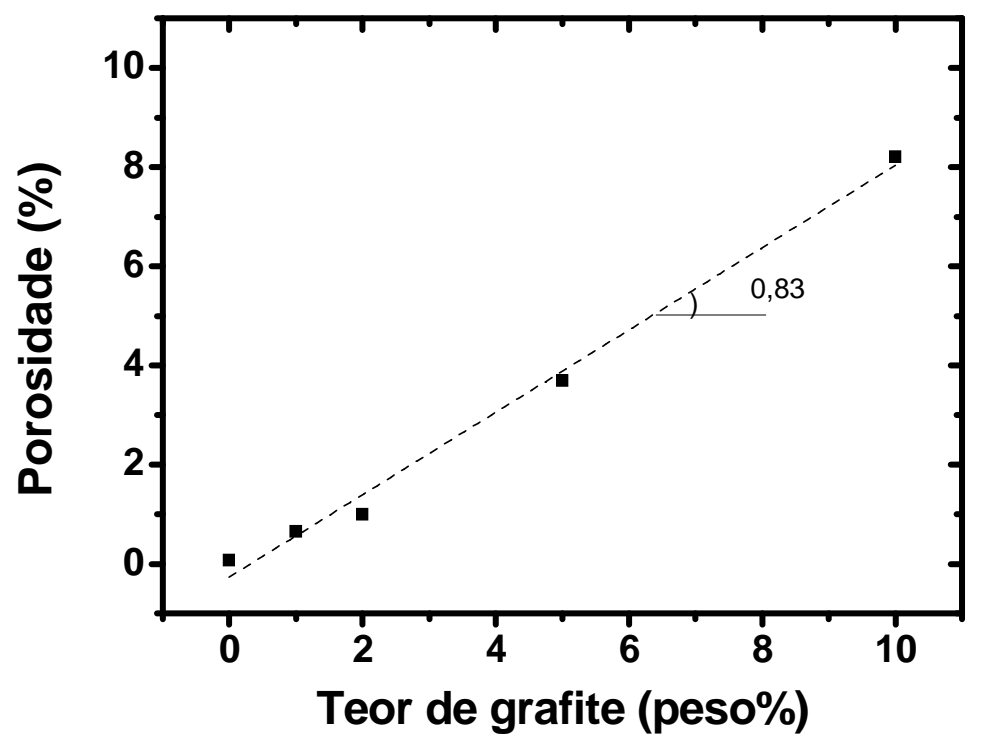

Figura 19 - Porosidade da amostra sinterizada de $\mathrm{ZrO}_{2}: 8 \mathrm{~mol} \% \mathrm{Y}_{2} \mathrm{O}_{3}$ em função do teor de grafite adicionado.

A equação (3.2.3) relaciona a porosidade $(P)$ do material com o teor de grafite ( $\left.\mathrm{X}_{\text {Graf. }}\right)$ adicionado, conforme a reta pontilhada da Figura 19.

$$
P=0,83 \cdot X_{\text {Graf }}
$$

Comparando as três equações, (3.2.1), (3.2.2) e (3.2.3), tem-se que para um determinado teor de grafite é possível obter um mesmo valor de porosidade com um valor um pouco menor de cloreto de sódio do que de iodeto de potássio, porém, utilizando este são obtidas amostras com tamanho médio de grão menor, o que influencia na condutividade elétrica do material, e próximo dos valores obtidos com adição de grafite.

A condutividade elétrica das amostras foi analisada por espectroscopia de impedância. A Figura 20 apresenta os diagramas de impedância obtidos para amostra com adição de iodeto de potássio (Figura 20a), cloreto de sódio (20b) e grafite (20c). 
(a)

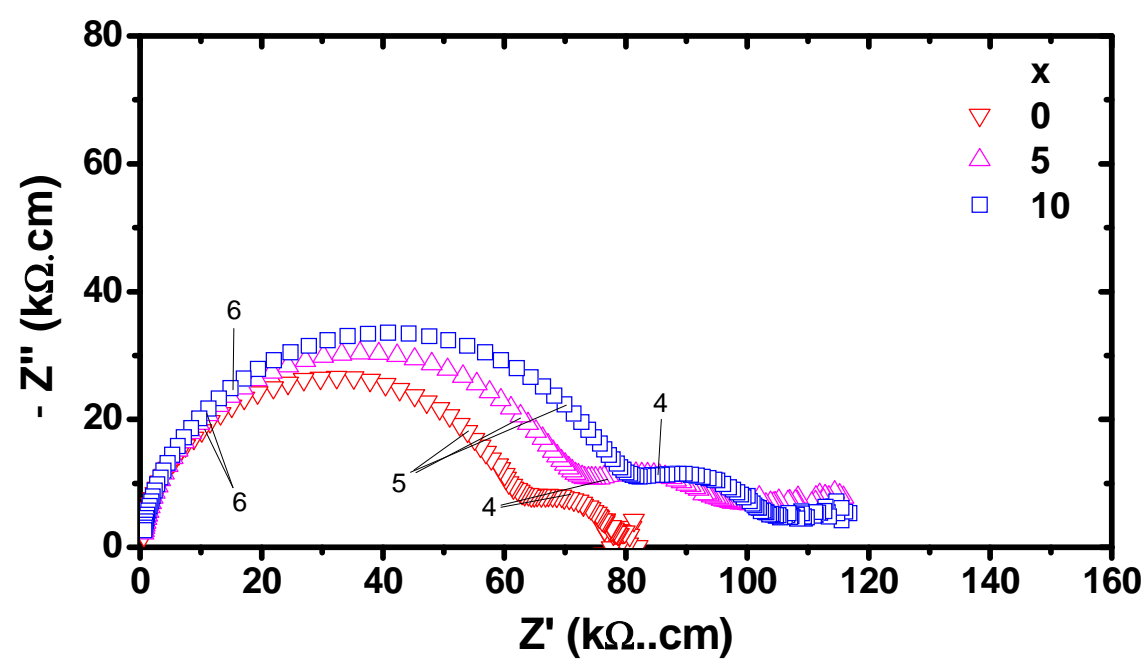

(b)

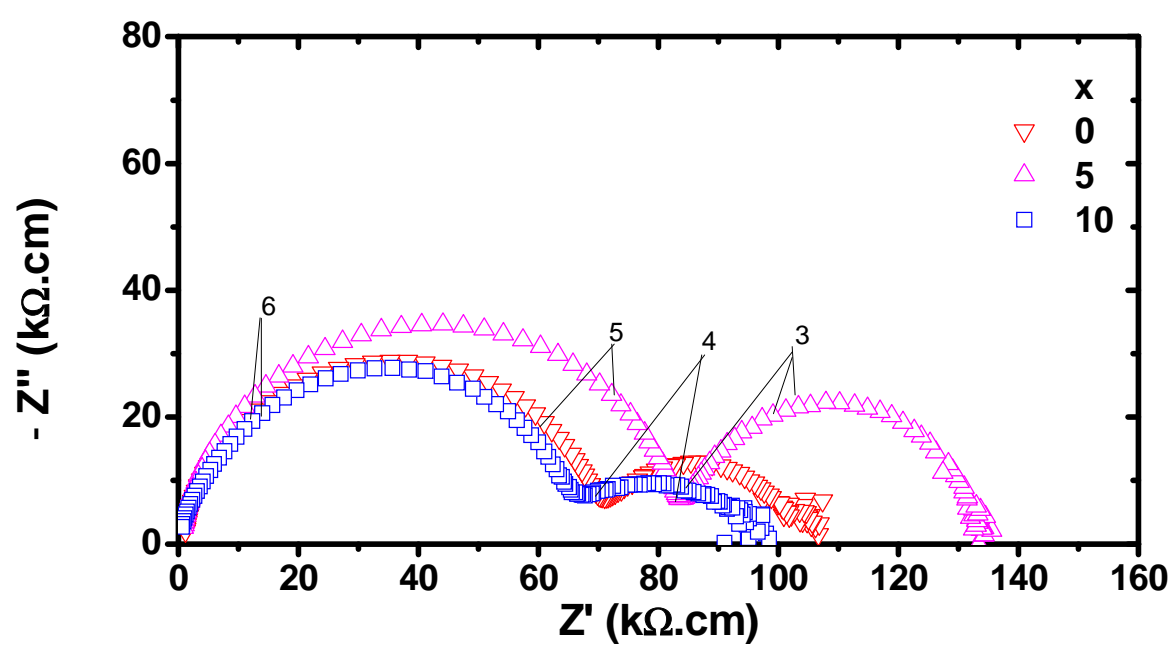

(c)

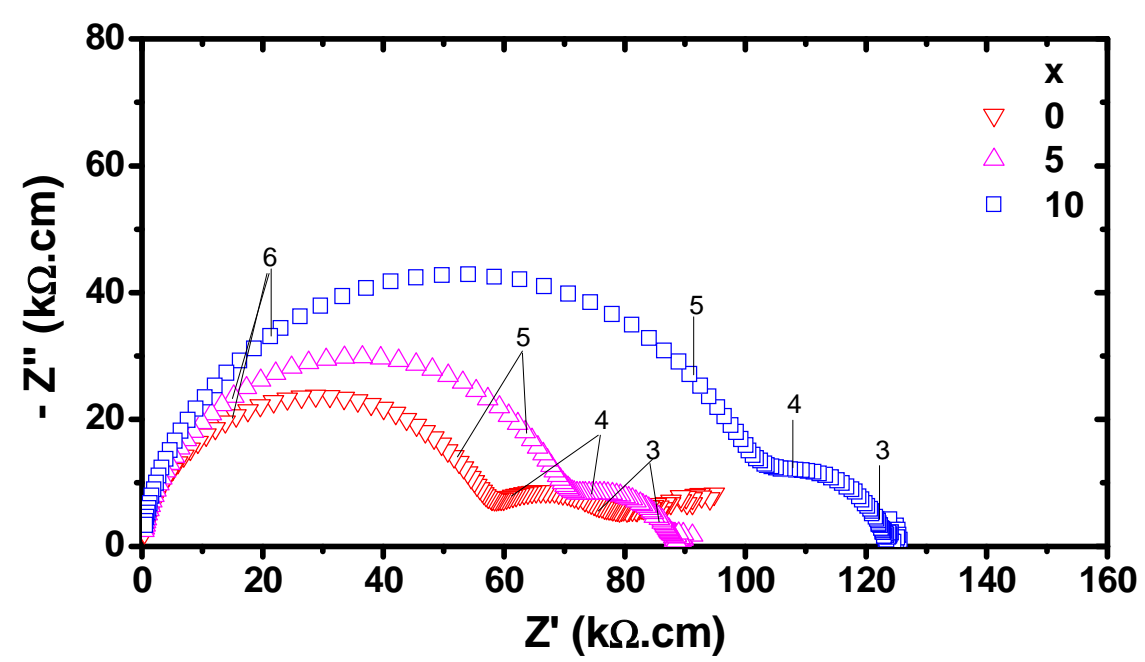

Figura 20 - Diagramas de impedância de $\mathrm{ZrO}_{2}: 8$ mol\% $\mathrm{Y}_{2} \mathrm{O}_{3}+x$ peso\% de (a) $\mathrm{KI}$ medidos a $323 \stackrel{\circ}{\circ}$, (b) $\mathrm{NaCl}$ medidos a $325^{\circ} \mathrm{C}$ e (c) grafite medidos a $329{ }^{\circ} \mathrm{C}$. Os números representam o logaritmo da frequência do sinal aplicado. 
Os diagramas de impedância são compostos basicamente de dois semicírculos: um a altas frequências, devido a contribuição intragranular (grãos) e outro a baixas frequências, devido à contribuição intergranular (contornos de grão, poros, etc.)

A Figura 21 apresenta os valores do ângulo de descentralização $\beta$ para as amostras de zircônia:ítria com adição de iodeto de potássio (21a) e cloreto de sódio (21b).

(a)

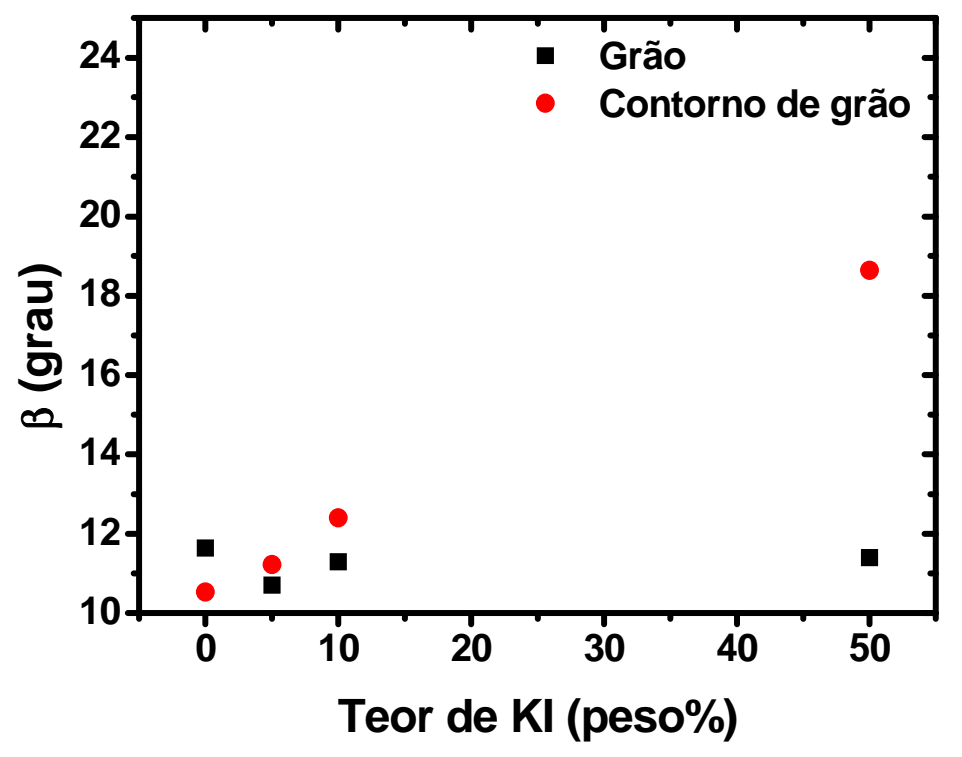

(b)

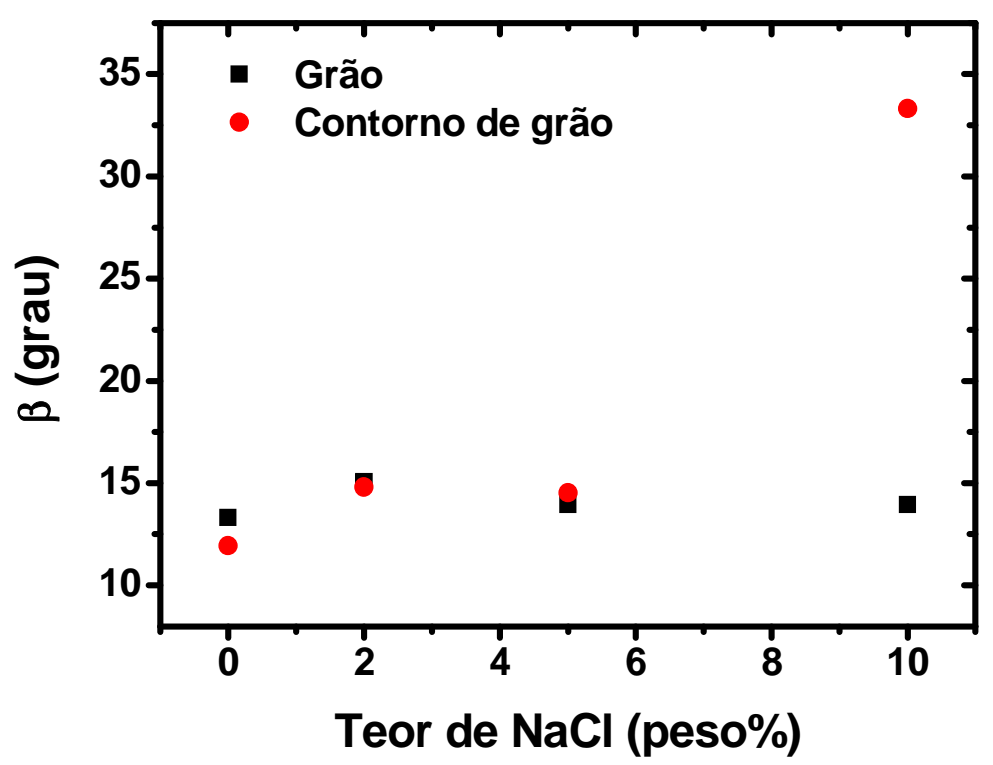

Figura 21 - Variação do ângulo de descentralização $\beta$ do semicírculo do diagrama de impedância de $\mathrm{ZrO}_{2}: 8 \mathrm{~mol} \% \mathrm{Y}_{2} \mathrm{O}_{3}$ com diferentes teores de iodeto de sódio (a) e de cloreto de sódio (b). 
Conforme esperado o aumento da porosidade provoca mudanças no diagrama de impedância ${ }^{[28,29]}$. O ângulo de descentralização para o semicírculo referente a contribuição do grão praticamente não sofre alteração, enquanto que o ângulo para o semicírculo referente ao contorno de grão aumenta com o aumento do teor do aditivo, tanto para o iodeto de potássio quanto para o cloreto de sódio. Isso mostra que o aditivo não provocou modificações na homogeneidade do grão, aumentando apenas a heterogeneidade dos contornos de grão devido aos poros.

A Figura 22 apresenta o circuito equivalente, com resistência em paralelo com o Elemento de Fase Constante, que representa os diagramas de impedância obtidos.

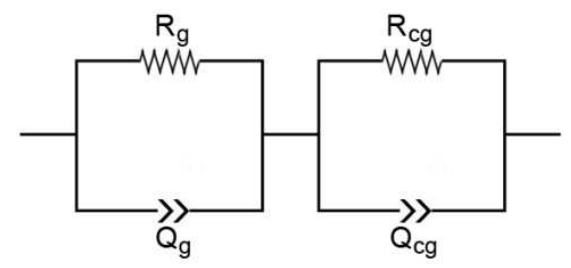

Figura 22 - Circuito equivalente composto por uma resistência em paralelo com um Elemento de Fase Constante.

O diagrama das amostras é representado pelo circuito com $\mathrm{R} / /$ EFC referente ao grão, em série com R // EFC referente ao contorno de grão. A Tabela 9 apresenta os valores de $Q$ tanto para o grão quanto para o contorno de grão, das amostras de zircônia estabilizada com ítria com os três diferentes aditivos.

Tabela 9 - Valores de $Q$ do grão e do contorno de grão de $\mathrm{ZrO}_{2}: 8$ mol\% $\mathrm{Y}_{2} \mathrm{O}_{3}$ com diferentes teores de iodeto de potássio, cloreto de sódio e grafite.

\begin{tabular}{c|ccc}
\hline & $\begin{array}{c}\text { Teor } \\
\text { (peso\%) }\end{array}$ & $\begin{array}{c}\mathrm{Q}_{\mathrm{g}} \\
\left(\mathrm{pF} . \mathrm{s}^{\mathrm{p}-1}\right)\end{array}$ & $\begin{array}{c}\mathrm{Q}_{\mathrm{cg}} \\
\left(\mathrm{nF} . \mathrm{s}^{\mathrm{p}-1}\right)\end{array}$ \\
\hline \multirow{3}{*}{$\mathrm{KI}$} & 0 & 98,0 & 15,3 \\
& 5 & 108,3 & 20,6 \\
& 10 & 85,6 & 8,26 \\
& 50 & 57,6 & 9,94 \\
\hline \multirow{3}{*}{$\mathrm{NaCl}$} & 0 & 116,2 & 37,8 \\
& 2 & 129,6 & 28,9 \\
& 5 & 94,6 & 4,66 \\
& 10 & 81,3 & 161,7 \\
\hline \multirow{3}{*}{ Grafite } & 0 & 81,1 & 56,1 \\
& 5 & 58,4 & 22,2 \\
& 10 & 54,8 & 6,86 \\
\hline
\end{tabular}


Os dados mostram que o valor de $Q$ para a região intergranular (contorno de grão e poros) é cerca de $10^{2}$ vezes maior quando comparado com o valor de $Q$ para os grãos, isto evidencia que o tamanho médio de grão é cerca de $10^{2}$ vezes a distância média intergranular.

Com a adição do formador de poro ocorre um aumento na resistividade tanto intergranular quanto intragranular. A Figura 23 apresenta os valores de resistividade do grão e do contorno de grão das amostras de zircônia:ítria com adição de iodeto de potássio (Figura 23a), cloreto de sódio (23b) e grafite (23c), obtidos a partir de análise da Figura 20. 
(a)

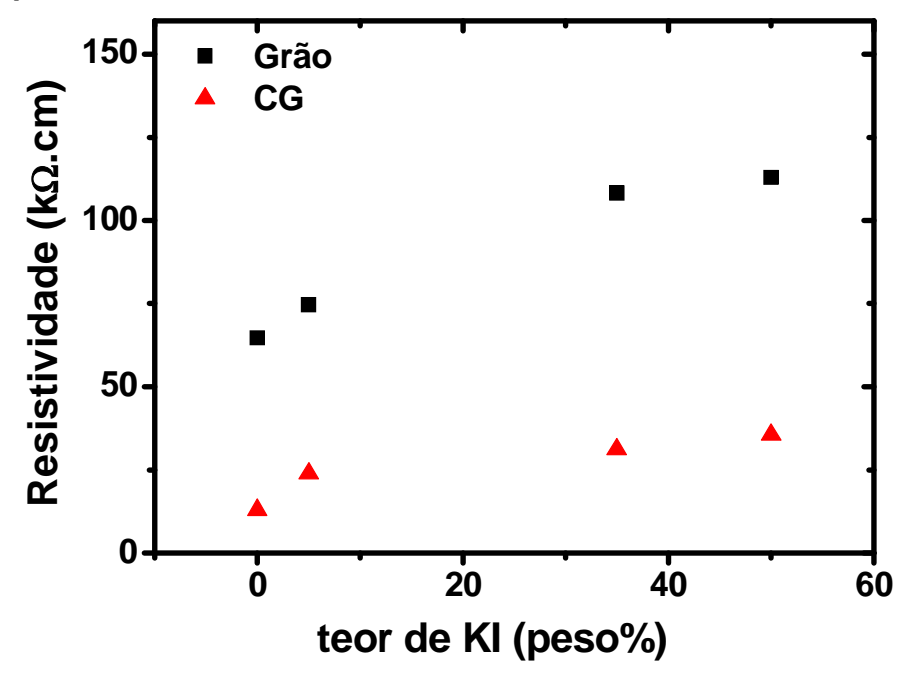

(b)

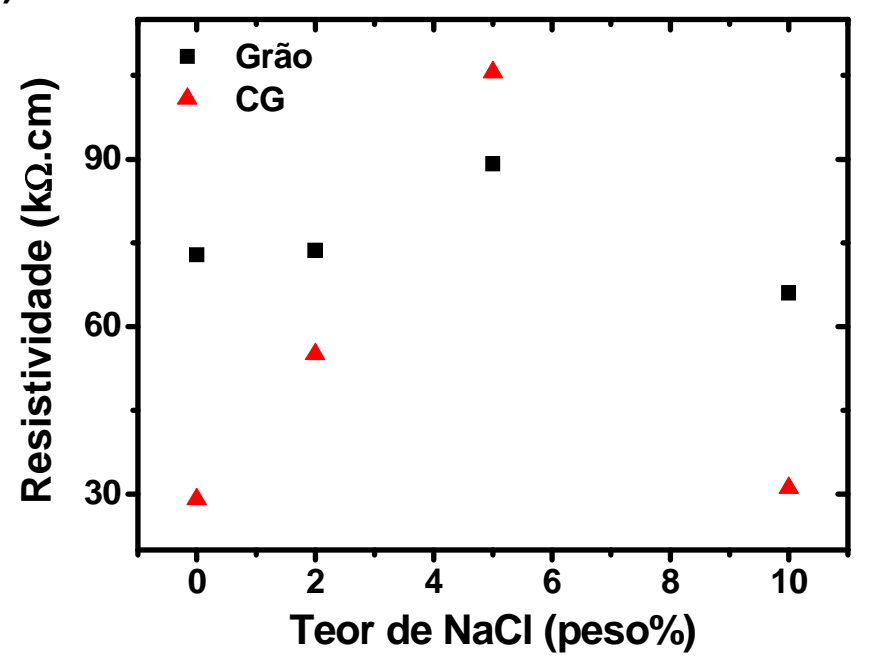

(c)

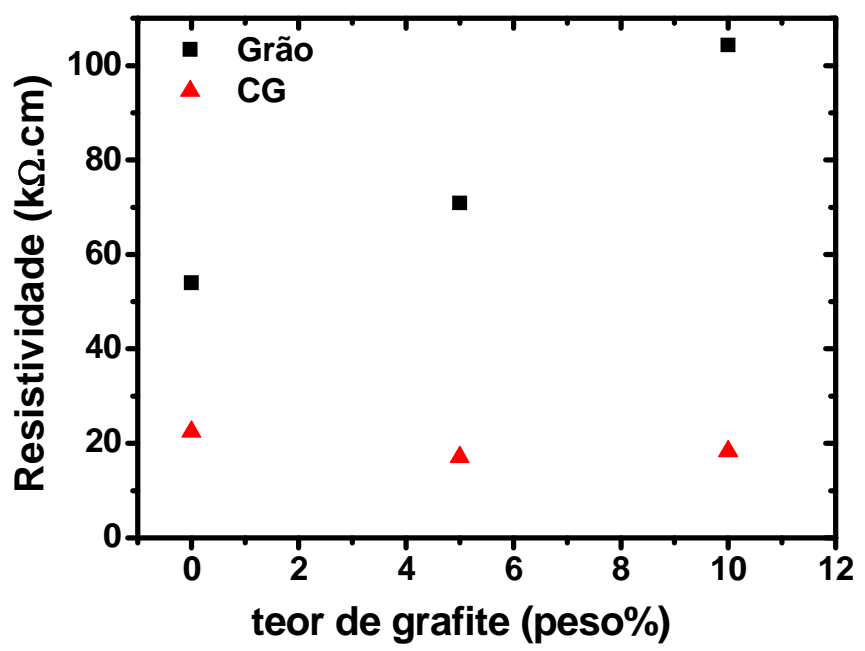

Figura 23 - Resistividade do grão e do contorno de grão de $\mathrm{ZrO}_{2}: 8$ mol\% $\mathrm{Y}_{2} \mathrm{O}_{3}$ em função do teor do formador de poro adicionado. (a) $\mathrm{KI}$, (b) $\mathrm{NaCl}$ e (c) grafite. 
Para as amostras de zircônia:ítria com adição de iodeto de potássio (Figura 23a), há aumento da resistividade intergranular e intragranular com o aumento do teor de aditivo. Esta variação da resistividade está associada à presença de poros na amostra, que dificulta a passagem dos portadores de carga.

Para a amostra com adição de 10 peso\% de $\mathrm{NaCl}$ (Figura 23b), observa-se um decréscimo no valor da resistividade tanto do grão quanto do contorno de grão, quando comparada com os outros teores de $\mathrm{NaCl}$. Este fato pode estar associado ao tamanho médio de grão desta amostra. Estudos mostram que a resistividade está diretamente associada à densidade de contornos ${ }^{[39]}$, que por sua vez está relacionada com o tamanho médio de grão. Por apresentar um tamanho médio de grão maior, a amostra possui uma densidade menor de contornos de grão, diminuindo, assim, o número de barreiras bloqueadoras de portadores de carga.

A Figura 24 apresenta os gráficos do fator de bloqueio $\alpha_{R}$, do fator de frequência $\alpha_{f}$ e do produto $\alpha_{R} \cdot \alpha_{R}$, fator proporcional ao volume intergranular, para amostras de zircônia:ítria com adição de iodeto de potássio.

(a)

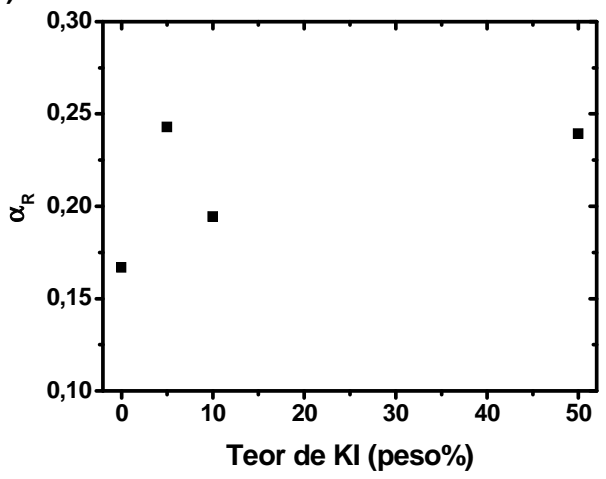

(b)

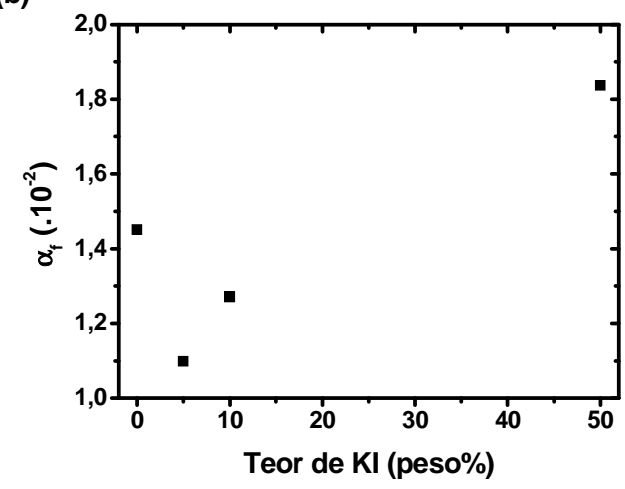

(c)

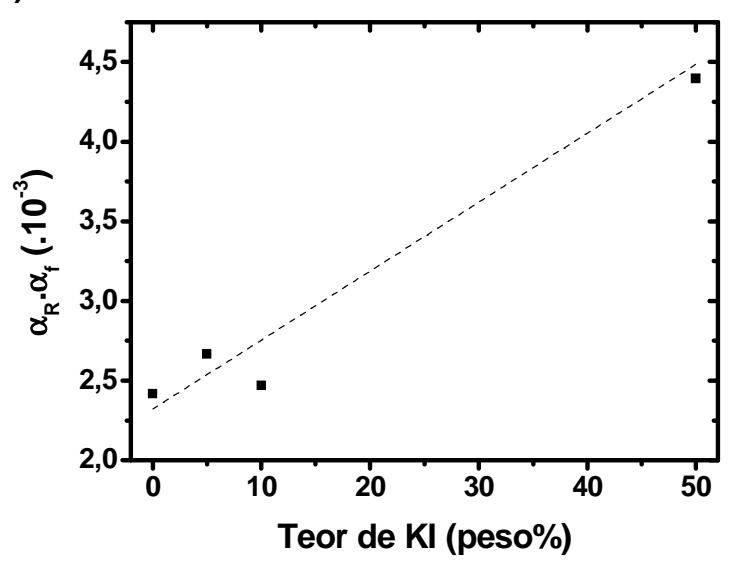

Figura 24 - Variação do fator de bloqueio (a), fator de frequência (b) e o produto (c) entre esses dois fatores $\left(\alpha_{\mathrm{R}} \cdot \alpha_{\mathrm{f}}\right)$ com o teor de $\mathrm{KI}$ adicionado a $\mathrm{ZrO}_{2}: 8 \mathrm{~mol} \% \mathrm{Y}_{2} \mathrm{O}_{3}$. 
Tanto o fator de bloqueio $\alpha_{R}$ quanto o fator de frequência $\alpha_{f}$ aumentam com 0 aumento do teor de iodeto de potássio (Figuras 24a e 24b), sugerindo que a adição de KI em zircônia:ítria provoca a formação de poros que aumentam a sua resistividade elétrica, aumentando a fração de portadores de carga bloqueados nos contornos de grão. Quanto ao formato do poro, sabe-se que tanto a área intergranular quanto a distância intergranular aumentaram com o aumento do teor de aditivo.

Há um aumento da porosidade das amostras, que pode ser evidenciado pelo aumento de $\alpha_{R} \cdot \alpha_{f}$. Por meio da equação da reta pontilhada da Figura $24 c$ e a Equação (3.2.1) é possível estabelecer a relação entre a porosidade da amostra e o parâmetro $\alpha_{R} \cdot \alpha_{f}:$

$$
P=\frac{0,77 \cdot\left(\alpha_{R} \cdot \alpha_{f}\right)-1,5 \cdot 10^{-3}}{4,3 \cdot 10^{-5}}
$$

sendo $\mathrm{P}$ a porosidade do material sinterizado nas condições deste trabalho.

Esse mesmo tipo de análise pode ser feito para zircônia:ítria com adição de cloreto de sódio. A Figura 25 apresenta os valores dos fatores $\alpha_{R}$, $\alpha_{f}$ e do produto $\alpha_{R} \cdot \alpha_{f}$ em função do teor de cloreto de sódio. 
(a)

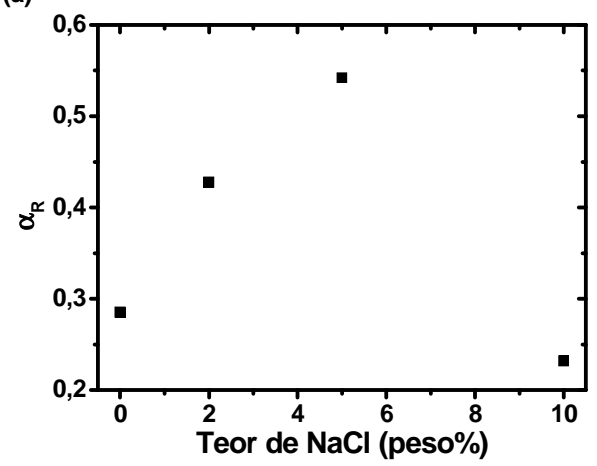

(b)

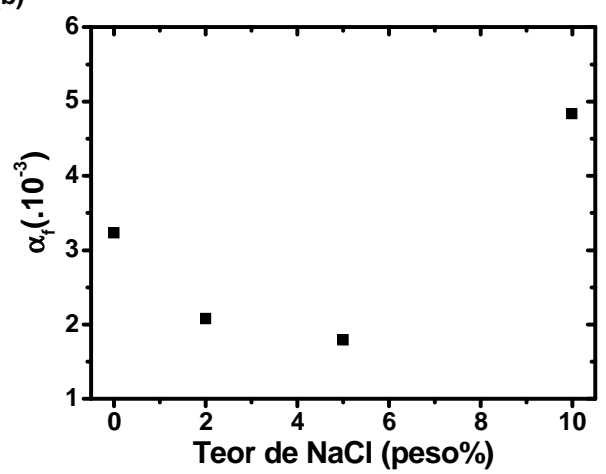

(c)

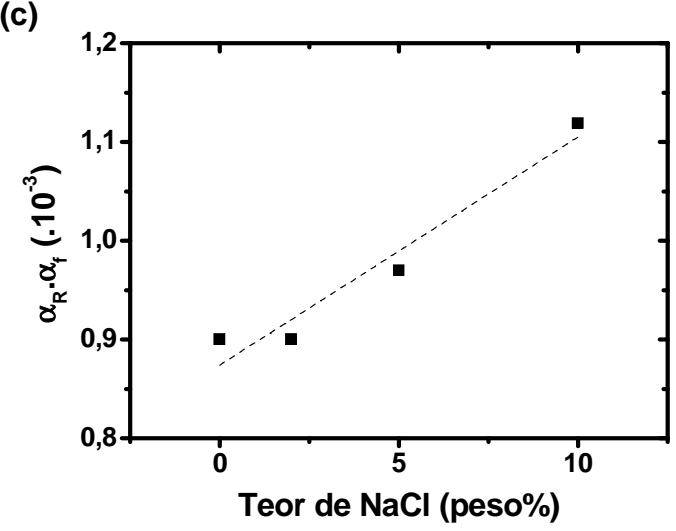

Figura 25 - Valores do fator de bloqueio (a), do fator de frequência (b) e do produto (c) entre esses dois fatores $\left(\alpha_{\mathrm{R}} \cdot \alpha_{\mathrm{f}}\right)$ com o teor de $\mathrm{NaCl}$ adicionado a $\mathrm{ZrO}_{2}: 8 \mathrm{~mol} \% \mathrm{Y}_{2} \mathrm{O}_{3}$.

$\mathrm{O}$ fator de bloqueio aumenta com o aumento do teor de $\mathrm{NaCl}$ (Figura 25a), enquanto que o fator de frequência diminui (Figura 25b, exceto para $\mathrm{ZrO}_{2}: 8 \mathrm{~mol} \% \mathrm{Y}_{2} \mathrm{O}_{3}$ com $10 \%$ de $\mathrm{NaCl}$ ), sugerindo que ao adicionar $\mathrm{NaCl}$ há a formação de poros, aumentando a resistividade elétrica, influenciando consequentemente o fator de bloqueio. Quanto ao formato do poro, sabe-se que sua área normal ao campo aplicado aumentou, enquanto que sua espessura diminuiu. Pode-se inferir, portanto, que se têm poros mais largos, porém menos espessos.

Há um aumento da porosidade das amostras de zircônia:ítria com adição de cloreto de sódio que pode ser evidenciado pelo aumento de $\alpha_{R} \cdot \alpha_{f}$ (Figura 25c). Por meio da equação da reta pontilhada da Figura 25c e a Equação (3.2.2), é possível estabelecer a relação entre a porosidade da amostra e o produto $\alpha_{R} \cdot \alpha_{f}$, quando cloreto de sódio é o formador de poros, conforme mostra a Equação (3.2.5): 


$$
P=\frac{0,78 \cdot\left(\alpha_{R} \cdot \alpha_{f}\right)-6,6 \cdot 10^{-4}}{2,3 \cdot 10^{-5}}
$$

A Figura 26 apresenta, a fim de comparação, a variação dos fatores $\alpha_{R}, \alpha_{f}$ e do produto $\alpha_{R} \cdot \alpha_{f}$, de acordo com o teor de grafite adicionado na zircônia:ítria.

(a)

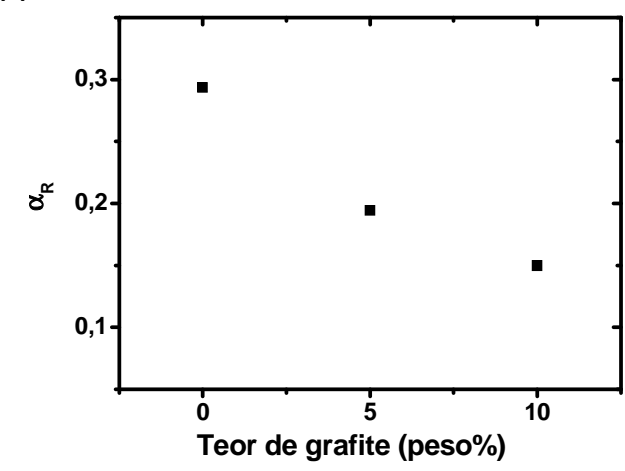

(b)

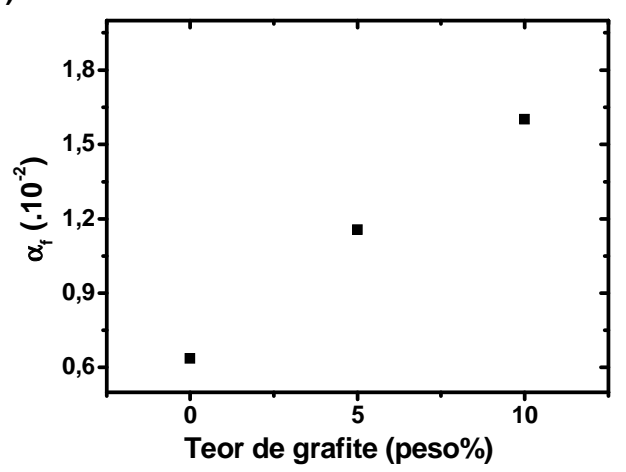

(c)

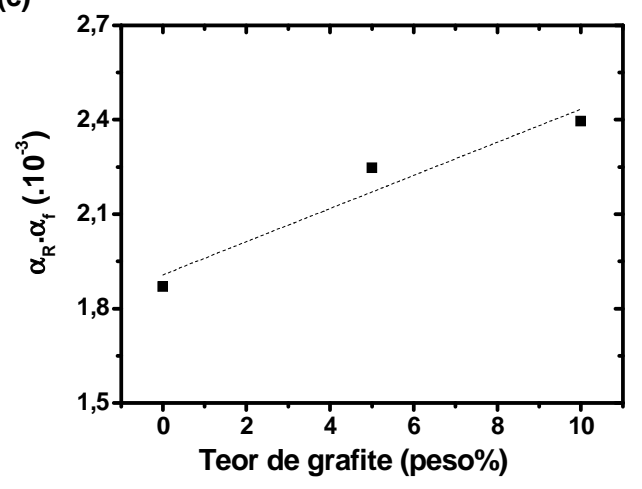

Figura 26 - Valores do fator de bloqueio (a), do fator de frequência (b) e do produto (c) entre esses dois fatores $\left(\alpha_{\mathrm{R}} \cdot \alpha_{\mathrm{f}}\right)$ com o teor de grafite adicionado a $\mathrm{ZrO}_{2}: 8 \mathrm{~mol} \% \mathrm{Y}_{2} \mathrm{O}_{3}$.

O uso de grafite como aditivo sacrificial provoca diminuição do fator de bloqueio $\alpha_{R}$ (Figura 26a), ou seja, ocorre diminuição da fração de portadores de carga bloqueados nos contornos de grão devido à diminuição da área intergranular. $O$ fator de frequência $\alpha_{f}$ aumenta com a adição de grafite, evidenciando um aumento da distância intergranular (Figura 26b).

Assim como para as amostras com adição de iodeto de potássio e de cloreto de sódio, a Figura 26 mostra que as amostras de $\mathrm{ZrO}_{2}: 8$ mol\% $\mathrm{Y}_{2} \mathrm{O}_{3}$ com adição de grafite (material comum utilizado como formador de poros para produção de anodos para SOFC's) ${ }^{[22]}$ apresentam aumento da porosidade, confirmado pelas análises por espectroscopia de impedância. 


\section{Procedimento para preparação de cerâmicas porosas de zircônia:ítria}

I. Utilizar Equação (3.2.1) para iodeto de potássio e Equação (3.2.2) para cloreto de sódio, para cálculos do teor de aditivo a ser utilizado para obtenção da porosidade necessária.

II. Pesagem das massas de $\mathrm{ZrO}_{2}: 8$ mol\% $\mathrm{Y}_{2} \mathrm{O}_{3}$ e do halogeneto alcalino $(\mathrm{NaCl}$ ou $\mathrm{KI}$ ) a ser utilizado.

III. Mistura dos materiais em almofariz de ágata aquecido devido a higroscopicidade do aditivo.

IV. Compactação uniaxial ( $50 \mathrm{MPa} / 1 \mathrm{~min})$ e isostática ( $200 \mathrm{MPa} / 1 \mathrm{~min})$

V. Sinterização da amostra utilizando a seguinte programação: taxa de aquecimento e resfriamento de $5^{\circ} \mathrm{C} / \mathrm{min}$, com dois patamares, o primeiro a $\mathrm{T} / 1$ h e o segundo a $1400 \stackrel{\circ}{\circ} / 2 \mathrm{~h}$, sendo $\mathrm{T}$ a temperatura de fusão do aditivo utilizado $\left(686{ }^{\circ} \mathrm{C}\right.$ para $\mathrm{Kl}$ e $801^{\circ} \mathrm{C}$ para $\left.\mathrm{NaCl}\right)$ 


\section{CONCLUSÕES}

Cerâmicas porosas de zircônia:ítria foram preparadas com diferentes teores de iodeto de potássio e cloreto de sódio como aditivo sacrificial.

A temperatura ótima de eliminação dos aditivos foi determinada pela análise termogravimétrica e análise de fluorescência de raios $\mathrm{X}$. Quando usada a temperatura de fusão dos aditivos ( mesma temperatura em que inicia a perda de massa) não foi detectado resíduo do aditivo por análise de fluorescência de raios $X$.

O teor de poros foi analisado por meio de observação de micrografias obtidas em microscópio eletrônico de varredura e em microscópio de varredura por sonda. Foi possível estabelecer uma relação linear entre o teor de aditivo e o valor de porosidade.

O comportamento elétrico estudado por espectroscopia de impedância apresentam de acordo com os reportados em estudos com trincas e poros em $\mathrm{ZrO}_{2}: 8$ mol\% $\mathrm{Y}_{2} \mathrm{O}_{3}{ }^{[27-29]}$. A formação de poros modificou o diagrama de impedância, apresentando um aumento da resistência total do compacto sinterizado e um aumento do ângulo de descentralização do semicírculo de baixas frequências, referente aos contornos de grãos e poros. $O$ produto dos fatores de bloqueio e de frequência $\alpha_{R} \cdot \alpha_{f}$ permitiu o estudo do aumento da porosidade por espectroscopia de impedância e foi possível estabelecer uma relação entre a porosidade da amostra e esse produto. 


\section{REFERÊNCIAS}

[1] ETSELL, T.H.; FLENGAS, S.N. The electrical properties of solid oxide electrolytes. Chemical Reviews, V.70, p.339-376, 1970

[2] COLOMBO, P.; DUNAND, D.C.; KUMAR, V. Advances in the synthesis, characterization, and properties of bulk porous materials - Porous materials: Less is more. Journal of Materials Research, V.28, p.2187-2190, 2013.

[3] ZHANG, S.; YUAN, L.; YU, J. Low temperature molten salt-mediated preparation of porous ceramics. International Ceramic Review, V.6, p.374-377, 2009.

${ }^{[4]}$ Capillary rise properties of porous mullite ceramics COLOMBO, P. In Praise of Pores. Science, V.322, p.381-383, 2008.

${ }^{[5]}$ SCHLICHTING, K.W.; PADTURE, N.P.; KLEMENS, P.G. Thermal conductivity of dense and porous yttria-stabilized zirconia. Journal of Materials Science, V.36, p.3003-3010, 2001

[6] NAIT-ALI, B.; HABERKO, K.; VESTEGHEM, H.; ABSI, J.; SMITH, D.S. Thermal conductivity of highly porous zirconia. Journal of the European Ceramic Society, V.26, p.3567-3574, 2006.

[7] ZHOU, J.; WANG C. Porous yttria-stabilized zirconia ceramics fabricated by nonaqueous-based gelcasting process with PMMA microsphere as pore-forming agent. Journal of the American Ceramic Society, V.96, p.266-271, 2013

[8] STUDART, A.R.; GONZENBACH, U.T.; TERVOORT, E.; GAUCKLER, J. Processing routes to macroporous ceramics: a review. Journal of the American Ceramic Society, V.89, p.1771-1789, 2006.

[9] DONG, Y.; WANG, C.; ZHOU, J.; HONG, Z. A novel way to fabricate highly porous fibrous YSZ ceramics with improved thermal and mechanical properties. Journal of the European Ceramic Society, V.32, p.2213-2218, 2012

[10] ZHANG, R.; FANG, D.; CHEN, X.; PEI, Y.; WANG, Z.; WANG, Y. Microstructure and properties of highly porous $\mathrm{Y}_{2} \mathrm{SiO}_{5}$ ceramics produced by a new water-based freeze casting. Materials and Design, V.46, p.746-750, 2013.

[11] HASHIMOTO, S.; UMEDA, T.; HIRAO, K.; KONDO, N.; ZHOU, Y.; HYUGA, H.; HONDA, S.; IWAMOTO, Y. Fabrication and characterization of porous $\mathrm{ZrO}_{2}$ with a high 
volume fraction of fine closed pores. Journal of the European Ceramic Society, V.33, p.61-66, 2013

[12] COLOMBO, P.; DEGISCHER, H.P. Highlyporousmetalsandceramics. Materials Science and Technology, V. 26, p.1145-1158, 2010.

[13] DUTRA, R.P.S.; de ARAUJO PONTES, L.R. Obtenção e análise de cerâmicas porosas com a incorporação de produtos orgânicos ao corpo cerâmico. Cerâmica, V.48, p.223-230, 2002.

${ }^{[14]}$ OKADA, K.; UCHIYAMA, S.; ISOBE, T.; KAMESHIMA, Y.; NAKAJIMA, A.; KURATA, T. Capillary rise properties of porous mullite ceramics prepared by an extrusion method using organic fibers as the pore former. Journal of the European Ceramic Society, V.29, p.2491-2497, 2009.

[15] AlBANO, M.P.; GARRIDO, L.B.; PLUCKNETT, K.; GENOVA, L.A. Processing of porous yttria-stabilized zirconia tapes: Influence of starch content and sintering temperature. Ceramics International, V.35, p.1783-1791, 2009.

${ }^{[16]}$ MINH, N.Q. Solid oxide fuel cell technology - features and applications. Solid State Ionics, V.174, p.271-277, 2004.

${ }^{[17]}$ de FLORIO, D.Z.; FONSECA, F.C.; MUCCILLO, E.N.S.; MUCCILLO, R. Materiais cerâmicos para células a combustível. Cerâmica, V.50, p.275-290, 2004.

[18] JIANG, S.P.; CHAN, S.H. A review of anode materials development in solid oxide fuel cells. Journal of Materials Science, V.39, p.4405-4439, 2004.

${ }^{[19]}$ ZHU, W.Z.; DEEVI, S.C. A review on the status of anode materials for solid oxide fuel cells. Materials Science and Engineering, A632, p.228-239, 2003.

[20] JIANG, S.P.; CHAN, S.H. Development of $\mathrm{Ni} / \mathrm{Y}_{2} \mathrm{O}_{3}-\mathrm{ZrO}_{2}$ cermet anodes for solid oxide fuel cell. Materials Science and Technology, V.20, p.1109-1118, 2004.

[21] JIANG, S.P.; CALLUS, P.J.; BADWAL, S.P.S. Fabrication and performance of Ni/3 mol\% $\mathrm{Y}_{2} \mathrm{O}_{3}-\mathrm{ZrO}_{2}$ cermet anodes for solid oxide fuel cells. Solid State Ionics, V.132, p.1-14, 2000.

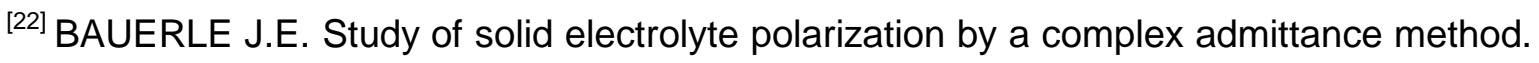
Journal of Physics and Chemistry of Solids, V.30, p.2657-2670, 1969. 
${ }^{[23]}$ Impedance Spectroscopy, Emphasizing solid materials and systems, Ed. J. Ross Macdonald, John Wiley \& Sons, 1987

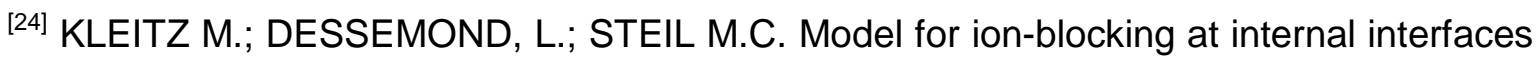
in zirconias. Solid State Ionics, V.75, p.107-115, 1995.

[25] BRUG G.J.; VAN DEN EEDEN A.L.G.; SLUYTERS-REHBACH M.; SLUYTERS J.H.The Analysis of Electrode Impedances Complicated by the Presence of a Constant Phase Element. Journal of Electroanalytical Chemistry, V.176, p.275-295, 1984.

${ }^{[26]}$ Électrochimie des Solides, Exercices corrigés avec rappels de cours, EDP Sciences, Hammou, Abdelkader; Georges, Samuel, 2011.

[27] KLEITZ M.; PESCHER C.; DESSEMOND, L. Impedance spectroscopy of microstructure defects and crack characterization. Science and Technology of Zirconia V, (Technomic Publ. Co., Inc., 1993) p.593.

[28] MUCCILLO, R. Impedance spectroscopy analysis of zirconia:8 mol\% yttria solid electrolytes with graphite pore former. Journal of Materials Research, V.24, p.17801784, 2009

[29] DESSEMOND, L.; MUCCILLO R.; HÉNAULT M.; KLEITZ M. Eletric ConductionBlocking Effects of Voids and Second Phases in Stabilized Zirconia. Applied Physics A, V.57, p.57-60, 1993.

${ }^{[30]}$ GUO, X. Physical origin of the intrinsic grain-boundary resistivity of stabilized-zirconia: Role of space-charge layers. Solid State lonics, V.81, p.235-242, 1995.

[31] KLEITZ M.; STEIL M.C. Microstructure Blocking Effects Versus Effective Medium Theories in YSZ. Journal of the European Ceramic Society, V.17, p.819-829, 1997.

[32] DESSEMOND, L. Tese. (Grenoble, 1992) Spectroscopie d'impedance des fissures dans la zircone cubique

[33] De FLORIO D.Z.; MUCCILLO R. Sintering of zirconia-yttria ceramics studied by impedance spectroscopy. Solid State Ionics, V.23, p.301-305, 1999.

[34] STEIL M.C.; THEVENOT F.; KLEITZ M. Densification of Yttria-Stabilized Zirconia: Impedance Spectroscopy Analysis. Journal of the Electrochemical Society, V.144, p.390-398, 1997. 
[35] GIESCHE, H. Mercury Porosimetry: A General (Practical) Overview. Particle \& Particle Systems Characterization, V.23, p.9-19, 2006.

[36] Programa desenvolvido por Wayne Rasband, National Institute of Mental Health, acessado em http://rsbweb.nih.gov/ij/

[37] MENDELSON, M.I. Average grain size in polycrystalline ceramics. Journal of the American Ceramic Society, V. 52, n. 8, p. 443-446, 1969.

${ }^{[38]}$ KLEITZ, M.; KENNEDY, J.H. Resolution of multicomponents impedance diagrams. In: Proceedings of the International Conference on Fast Ion Transport in Solids, Electrodes and Electrolytes, ed. Vashishta, P.; Mundy, J.N.; Shenoy. G.K. North-Holland, Amsterdam, p.1858, 1979.

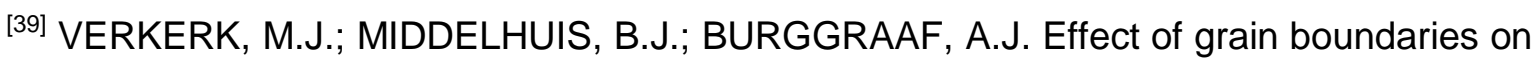
the conductivity of high-purity $\mathrm{ZrO}_{2}-\mathrm{Y}_{2} \mathrm{O}_{3}$ ceramics. Solid State Ionics, V.6, p.159-170, 1982. 